\begin{abstract}
UNIVERSIDADE DE SÃO PAULO
FACULDADE DE MEDICINA DE RIBEIRÃO PRETO

PROGRAMA DE PÓS-GRADUAÇÃO EM BIOQUÍMICA
\end{abstract}

JÉSSICA DE MOURA SOARES

Um Sistema Biomimético Nanoestruturado para a Hidrólise Enzimática de Xiloglucano

Ribeirão Preto 
JÉSSICA DE MOURA SOARES

Um Sistema Biomimético Nanoestruturado para a Hidrólise Enzimática de Xiloglucano

\section{Versão Original}

Dissertação de mestrado apresentada ao Programa de Pós-graduação em Bioquímica como parte dos requisitos para obtenção do título de Mestre em Ciências Area de concentração: Bioquímica.

Orientador: Prof. Dr. Richard John Ward

Ribeirão Preto 
Autorizo a reprodução e divulgação total ou parcial deste trabalho, por qualquer meio convencional ou eletrônico, para fins de estudo e pesquisa, desde que citada a fonte.

Soares, Jéssica de Moura

Um Sistema Biomimético Nanoestruturado para a Hidrólise

Enzimática de Xiloglucano. Ribeirão Preto, 2010.

120 p. : il. ; $30 \mathrm{~cm}$

Dissertação de Mestrado, apresentada à Faculdade de Medicina de Ribeirão Preto/USP. Área de concentração: Bioquímica.

Orientador: Ward, Richard John.

1. Xiloglucanases. 2. Imobilização multi-enzimática. 3 Nanopartículas. 4. Sacarificação. 5. Biomimética molecular. 
FOLHA DE AVALIAÇÃO

\author{
Jéssica de Moura Soares
}

\title{
Um Sistema Biomimético Nanoestruturado para a Hidrólise Enzimática de Xiloglucano
}

Dissertação de mestrado apresentada ao Programa de Pós-graduação em Bioquímica como parte dos requisitos para obtenção do título de Mestre em Ciências

Area de concentração: Bioquímica.

Aprovado em:

\section{Banca Examinadora}

Prof. Dr.

Instituição: Julgamento:

Prof. Dr.

Instituição: Julgamento:

Prof. Dr.

Instituição: Julgamento:

Prof. Dr.

Instituição: Julgamento: 
$\mathcal{A}$ meus país, Márcia e $\mathcal{N}$ eto, por seu amor e apoí incondicional. 


\section{AGRADECIMENTOS}

À toda a minha família, Moura e Soares, principalmente aos meus pais Márcia e Neto, por todo o apoio que me deram até hoje e que com certeza contribuiu para que eu conquistasse tudo o que conquistei até aqui, mesmo quando foi necessário ficar distante do lar.

Ao meu orientador Prof. Dr. Richard John Ward, por ter primeiramente apostado em mim e me recebido tão gentilmente como sua aluna, por desenvolver junto comigo este ambicioso projeto e por sempre me orientar paciência e otimismo. Mesmo quando as coisas não saíam como esperávamos, sempre acreditou no meu potencial e me encorajou a prosseguir e esteve sempre disponível para esclarecer dúvidas, ou pensar nelas em conjunto e para ouvir minha ideias.

Aos colegas de laboratório por toda a ajuda e conselhos que me ajudaram a concluir este trabalho. À Luana Parras Meleiro e à Sibeli de Carli pelas incontáveis ajudas no início do mestrado, quando muita coisa era novidade pra mim e, em especial, à paciência da Luana em me ajudar com cinética enzimática e cultivo de levedura. Aos colegas Carolina Victal, José Carlos Salgado e Susana Amigo pela convivência e ajuda no dia-a-dia. Ao colega Matheus Quintana Barreto pelo humor de sempre, que ajudava os dias a parecerem mais curtos e os experimentos mais divertidos e pela companhia até mesmo nos finais de semana que precisei ir à bancada. Ao André Justino, técnico do laboratório, pela disponibillidade de ajudar sempre. Às bolsistas técnicas que passaram pelo laboratório Letícia e Suelen pela dedicação e capricho na preparação dos materiais e ao bolsista Rafael, também pela dedicação e cuidado e a disponibilidade em nos auxiliar sempre que pedimos. À ex-aluna do laboratório Lara Aparecida Buffoni de Campos Carneiro, que desenvolveu o nanomaterial com o qual trabalhei, pela disponobilidade e paciência em ajudar e tirar todas as minhas dúvidas, especiamente nas imobilização das enzimas e na interpretação dos dados de espectrometria de massas.

À Natália Fontana pela ajuda com cromatografia e ao técnico Eduardo Crevelin pela ajuda com a Espectrometria de Massas.

Às colegas e amigas que a FMRP me deu Ana Paula, Mariana Rocha e Mariana Zerbini pela companhia e apoio nos estudos e na vida. Aos demais colegas do prédio central, incluindo aqueles do Laboratório de Biotecnologia Molecular que me foram apresentados pelo Matheus, pela parceria.

Ao programa de Pós-Graduação em Bioquímica da FMRP e todo seu corpo docente pela formação e auxílio científico. À Maria Ivone Campos, secretária do programa, por toda a ajuda em resolver os trâmites e burocracias. 
Ao departamento de Química da FFCLRP pela infraestrutura utilizada. Aos colegas da química Elise Marques pela ajuda, conversas e viagens, ao Bruno Biagi pelos deliciosos cookies e Aline Vianna Bernardi pela companhia na disciplina de imobilização de enzimas.

A todos os amigos que fiz em Ribeirão Preto e que me acolheram nesta cidade. À Sarah Santangelo, que dividiu apartamento comigo no primeiro ano do mestrado pela companhia. Ao Patrício Lopez Friera, com quem divido o lar agora, por todo amor e apoio, por tornar o fardo menos pesado e por aguentar minhas crises de pessimismo.

A todos os meus amigos de Fortaleza, que mesmo longe não deixam de me ajudar e torcer por $\operatorname{mim}$.

O presente trabalho foi realizado com apoio da Coordenação de Aperfeiçoamento de Pessoal de Nível Superior - Brasil (CAPES) e da Fundação de Amparo à Pesquisa do Estado de São Paulo (FAPESP, Processo 2017/14452-1). 
"Science and everyday life cannot and should not be separated." Rosalind Franklin 


\section{RESUMO}

\section{SOARES, J. M. Um Sistema Biomimético Nanoestruturado para a Hidrólise Enzimática de}

Xiloglucano. 2019. 120f. Dissertação (Mestrado). Faculdade de Medicina de Ribeirão Preto Universidade de São Paulo, Ribeirão Preto, 2019.

Os materiais lignocelulósicos são subprodutos agroindustriais muito abundantes que constituem uma fonte de carbono renovável que pode ser empregada na produção de biocombustíveis, como o etanol de segunda geração. O xiloglucano é uma hemicelulose e um dos polissacarídeos mais abundantes nestes materiais e pode ser totalmente hidrolisado pela ação conjunta de, pelo menos, quatro diferentes enzimas. A abordagem de imobilização de proteínas em nanomateriais oferece a possibilidade de co-localizar diferentes atividades enzimáticas em estruturas desenhadas com objetivo de mimetizar reações biológicas, e até mesmo vias metabólicas inteiras. Além disso, o emprego de nanomateriais na imobilização de enzimas pode incrementar o efeito sinérgico devido à proximidade entre os centros catalíticos. Neste trabalho, realizou-se o estudo da imobilização de quatro enzimas ativas na despolimerização do xiloglucano para o desenvolvimento de nanoestruturas biomiméticas, sendo os principais objetivos: a expressão das enzimas endo- $\beta$-1,4glucanase, específica de xiloglucano, $\beta$-galactosidase, $\alpha$-xilosidase e $\beta$-glucosidase, e sua imobilização em nanopartículas magnéticas e consequente caracterização da atividade dessas nanoestruturas sobre o xiloglucano. As enzimas expressas de forma heteróloga foram imobilizadas covalentemente, individualmente e em conjunto, em nanopartículas ferromagnéticas, as quais foram obtidas a partir de óxido de ferro $\left(\mathrm{Fe}_{3} \mathrm{O}_{4}\right)$, revestidas com quitosana e reticuladas com glutaraldeído. As nanostruturas híbridas foram então testadas quanto a sua capacidade catalítica contra substratos sintéticos e xiloglucano extraído de sementes de jatobá (Hymenaea courbaril). A caracterização enzimática demonstrou diferenças para $\mathrm{pH}$ e temperatura ótimos determinados entre enzimas livre e imobilizadas. A enzima $\alpha$-xilosidase YicI imobilizada teve sua temperatura ótima aumentada em dez graus em relação à enzima livre. No entanto, atividade específica foi reduzida em todas as enzimas após a imobilização. A eficiência de ligação às partículas variou de 5 a $92 \%$ entre as enzimas. A enzima $\beta$-galactosidase Bga1 demonstrou a melhor eficiência de imobilização e também a maior capacidade de reuso, chegando a manter cerca de 50\% da atividade após dez ciclos. Ainda, foram realizados ensaios com diferentes proporções enzimáticas para otimização da hidrólise do xiloglucano pelos nanossistemas contendo as quatro enzimas. A capacidade de hidrólise do xiloglucano pelos nanossistemas foi determinada pela mensuração de glicose liberada após as reações e por espectrometria de massas dos produtos das reações. Todas as enzimas continuaram ativas após a co-imobilização no nanomaterial. Os resultados de espectrometria de massas 
indicaram a presença dos monossacarídeos xilose e glicose/galactose, nos produtos de hidrolise de xiloglucano, evidenciando a atividade de despolimerização das nanoestruturas híbridas contendo as quatro enzimas.

Palavras-chave: Xiloglucanases; Imobilização multi-enzimática; Nanopartículas; Sacarificação; Biomimética molecular. 


\begin{abstract}
SOARES, J. M. A Nanostructured Biomimetic System for the Enzymatic Hydrolysis of Xyloglucan. 2019. 120p. Dissertation (Master). Faculdade de Medicina de Ribeirão Preto Universidade de São Paulo, Ribeirão Preto, 2019.

Lignocellulosic materials are abundant agroindustrial byproducts and constitute a renewable carbon source that can be used for biofuel production, such as second-generation bioethanol. Xyloglucan is a hemicellulose and one of the most abundant polysaccharides in lignocellulose and it is entirely hydrolyzed by the combined action of at least four different enzymes. The approach of protein immobilization on nanomaterials offers the possibility of colocalisation of different enzymes on structures designed to mimic biological reactions, and even entire metabolic pathways. In addition, the use of nanomaterials in enzyme immobilization may increase the synergistic effect due to the proximity effect between the catalytic centers. In this work, the immobilization of four enzymes for xyloglucan depolymerization was studied, with the purpose of developing biomimetic nanostructures. The main objectives were: the expression of the enzymes - xyloglucan specific endo- $\beta$-1,4-glucanase, $\beta$-galactosidase, $\alpha$-xylosidase and $\beta$-glucosidase, and their immobilization on magnetic nanoparticles and consequent characterization of the activity of these nanostructures against xyloglucan. The heterologously expressed enzymes were covalently immobilized, individually and in combination, on ferromagnetic iron oxide $\left(\mathrm{Fe}_{3} \mathrm{O}_{4}\right)$ nanoparticles coated with chitosan and cross-linked with glutaraldehyde. These hybrid nanostructures were then tested for their catalytic capacity against synthetic substrates and xyloglucan extracted from Jatobá (Hymenaea courbaril) seeds. Enzymatic characterizations demonstrated differences for optimal $\mathrm{pH}$ and temperatures determined between free and immobilized enzymes. All enzymes remained active after co-immobilization on the nanomaterial, however specific activity was reduced for all enzymes after immobilization. The optimum temperature of immobilized $\alpha$-xylosidase YicI increased by ten degrees compared to the free enzyme. Binding efficiency on the particles ranged from 5 to $92 \%$ between enzymes. The enzyme $\beta$-galactosidase Bgal demonstrated the best immobilization efficiency as well as the highest reuse capacity, maintaining up to $50 \%$ of activity after ten cycles. In addition, assays with different enzymatic proportions were performed to optimize xyloglucan hydrolysis by the four enzyme-containing nanosystems. The capacity of xyloglucan hydrolysis by the nanosystems was determined by measuring glucose released after the reactions and by mass spectrometry of the reaction products. Mass spectrometry results indicated the presence of the xylose and glucose/galactose monosaccharides in the xyloglucan hydrolysis products, showing the depolymerization activity of the hybrid nanostructures containing the four enzymes.
\end{abstract}

Keywords: Xyloglucanases; Multi-enzymatic immobilization; Nanoparticles; Saccharification; Molecular Biomimetics. 


\section{LISTA DE FIGURAS}

Figura 1 Representação da estrutura do xiloglucano de reserva ....................................... 30

Figura 2 Estrutura tridimensional da enzima XegA …...................................................... 32

Figura 3 Estrutura tridimensional da enzima YicI ..................................................... 33

Figura 4 Estrutura tridimensional da enzima Bga1 .................................................... 33

Figura 5 Estrutura tridimensional da enzima Bgl1 .................................................... 34

Figura 6 Esquema da co-imobilização covalente das quatro enzimas ativas sobre o xiloglucano nas nanopartículas magnéticas ........................................................ 35

Figura 7 Sequência da região com os múltiplos sítios de clonagem do vetor

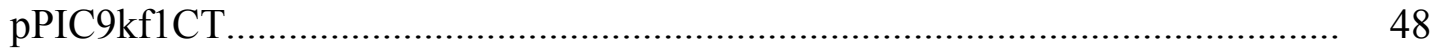

Figura 8 Gel de eletroforese de proteínas de expressão e purificação de XegA ................ 53

Figura 9 Gel de eletroforese de proteínas de expressão e purificação de YicI .................. 54

Figura 10 Parte da sequência do gene de Blg1 ............................................................... 55

Figura 11 Gel de eletroforese de DNA dos produtos de PCR de colônias após mutagênese sítio-dirigida de Bgl1

Figura 12 Gel de Eletroforese de DNA contendo fragmentos amplificados para a reação de CPEC

Figura 13 Gel de Eletroforese de DNA contendo o vetor linearizado ................................ 58

Figura 14 Gel de eletroforese de DNA contendo os produtos das reações de CPEC .......... 58

Figura 15 Géis de eletroforese de DNA contento produtos de PCR de colônias após transformação com os produtos de CPEC

Figura 16 Géis de eletroforese de DNA contento produtos de PCR de colônias após transformação com os produtos de ligação

Figura 17 Crescimento dos cultivos de P. pastoris GS115 para expressão das enzimas Bgal e Bgl1 ao longo dos dias de indução.

Figura 18 Atividade enzimática por mililitro dos cultivos de P. pastoris GS115 expressando Bgal e Bgll ao longodos 5 dias de indução

Figura 19 Gel de poliacrilamida 12,5\% contendo as alíquotas dos dias de expressão de Bga1......

Figura 20 Gel de poliacrilamida 12,5\% contendo as alíquotas dos dias de expressão de Bgl1

Figura 21 Géis de poliacrilamida 12,5\% contendo as frações eluídas na cromatografia de 
exclusão molecular

Figura 22 Densidade ótica das culturas de Bgal e Bgll ao longo de 96 horas (4 dias) de expressão

Figura 23 Atividade por mililitro dos cultivos de Bgal e Bgl1, ao longo de 96 horas (4 dias) de expressão

Figura 24 Densidade ótica das culturas de Bgal e Bgll ao longo de 72 horas (3 dias) de expressão

Figura 25 Atividade por mililitro dos cultivos de Bgal e Bgl1 ao longo de 72 horas (3 dias) de expressão.

Figura 26 Geis de eletroforese de proteínas contendo alíquotas dos dias de expressão de Bgal e Bgl1

Figura 27 Curvas de temperatura ótima da enzima YicI livre e imobilizada ...................... 76

Figura 28 Curvas de temperatura ótima da enzima XegA livre e imobilizada .................... 76

Figura 29 Curvas de temperatura ótima da enzima Bga1 livre e imobilizada .................... 77

Figura 30 Curvas de temperatura ótima da enzima Bgll livre e imobilizada ..................... 77

Figura 31 Curvas de $\mathrm{pH}$ ótimo da enzima YicI livre e imobilizada ................................. 78

Figura 32 Curvas de pH ótimo da enzima XegA livre e imobilizada ................................ 79

Figura 33 Curvas de $\mathrm{pH}$ ótimo da enzima Bgal livre e imobilizada ................................ 79

Figura 34 Curvas de pH ótimo da enzima Bgl1 livre e imobilizada ................................. 80

Figura 35 Atividade residual de YicI imobilizada em 5 ciclos de reuso ........................... 80

Figura 36 Atividade residual de XegA imobilizada em 3 ciclos de reuso .......................... 81

Figura 37 Atividade residual de Bgl1 imobilizada em de 3 ciclos de reuso....................... 81

Figura 38 Atividade residual da Bgal imobilizada ao decorrer de 10 ciclos de reuso......... 82

Figura 39 Espectros de massa dos produtos da hidrólise do xiloglucano com as quatro enzimas imobilizadas

Figura 40 Espectros de massa dos produtos da degradação do xiloglucano pelas enzimas imobilizadas nas nanopartículas

Figura 41 Resultado da cromatografia em camada delgada, TLC, dos produtos da degradação do xiloglucano de Jatobá pelas enzimas livres e imobilizadas

Figura 42 Quantidade de glicose liberada em cada ensaio contendo diferentes proporções das enzimas livres ou imobilizadas

Figura 43 Espectros de massa dos produtos da hidrólise do xiloglucano com os ensaios 2 e 4 
Figura 44 Espectros de massa dos produtos da hidrólise do xiloglucano com os ensaios 7, 8 e 10

Figura 45 Espectros de massa dos produtos da hidrólise do xiloglucano, ensaio controle negativo

Figura 46 Ensaios de reuso dos nanossistemas híbridos 


\section{LISTA DE TABELAS}

Tabela 1 Potencial de produção de etanol a partir da celulose presente nos resíduos de cada cultura ........................................................................ 25

Tabela 2 Potencial de produção de etanol a partir da hemicelulose presente nos resíduos de cada cultura ...................................................................... 26

Tabela 3 Componentes da reação CPEC ................................................................ 49

Tabela 4 Oligonucleotídeos desenhados para a reação CPEC ................................ 57

Tabela 5 Média das quantidades de enzima oferecidas, não ligadas e imobilizadas e eficiência de imobilização ............................................................... 74

Tabela 6 Média das atividades específicas das enzimas livres e imobilizadas ......... 75

Tabela 7 Combinações de enzimas imobilizadas nas nanopartículas ...................... 84

Tabela 8 Ensaios de diferentes proporções em pmol das enzimas livres e imobilizadas para hidrólise de xiloglucano .......................................... 86

Tabela 9 Principais oligômeros que formam o xiloglucano de Jatobá .................... 90

Tabela 10 Quantidade relativa dos aminoácidos mais reativos em cada enzima ....... 103

Tabela 11 Comparação da caracterização enzimática realizada neste trabalho com trabalhos anteriores ................................................................... 105 


\section{LISTA DE ABREVIATURAS E SIGLAS}

\begin{tabular}{|c|c|}
\hline AB-NTA & ácido N- (5-amino-1-carboxi-pentil) iminodiacético \\
\hline BMGY & Buffered complex medium containing glycerol (meio de cultura) \\
\hline BMMY & Buffered complex medium containing methanol (meio de cultura) \\
\hline CAZy & Carbohydrate Active enZyme (Banco de dados) \\
\hline CBM & Carbohydrate binding domain (Domínio de ligação a carboidratos) \\
\hline CPEC & Circular Polymerase Extension Cloning \\
\hline Da & dálton \\
\hline DO & densidade óptica \\
\hline DNS & ácido dinitrosalicílico \\
\hline dNTP & desoxirribonucleotídeos fosfatados \\
\hline EDTA & ácido etileno diamino tetracético \\
\hline ESI-MS & espectrometria de massas com fonte de ionização eletrospray \\
\hline g & aceleração da gravidade \\
\hline GH & glicosil hidrolases \\
\hline HDM & heavy density medium (meio rico para crescimento bacteriano) \\
\hline HEPES & ácido etano sulfônico 4-(2-hidroxieltil)-1-piperazina \\
\hline IPTG & isopropil- $\beta$-D-tiogalactopiranosídeo \\
\hline $\mathbf{K b}$ & quilobase $\left(10^{3} \mathrm{pb}\right)$ \\
\hline kDa & quilodálton \\
\hline $\mathbf{L B}$ & meio de cultura Luria-Bertani \\
\hline $\mathbf{M}$ & molar \\
\hline mg & miligrama \\
\hline$\mu \mathbf{L}$ & microlitro \\
\hline$\mu \mathbf{M}$ & micromolar \\
\hline $\min$ & minuto \\
\hline $\mathbf{m L}$ & mililitro \\
\hline $\mathbf{m M}$ & milimolar \\
\hline MS & espectrometria de massas \\
\hline $\mathbf{N i}$ & níquel $\left(\mathrm{Ni}^{2+}\right)$ \\
\hline nm & nanômetro \\
\hline nmol & nanomol \\
\hline
\end{tabular}




$\begin{array}{ll}\text { pb } & \text { pares de bases } \\ \text { PCR } & \text { reação em cadeia da polimerase } \\ \text { PDB } & \text { protein data bank } \\ p \text { NP } & \text { íon } p \text {-nitrofenolato } \\ p \text { NP-Gal } & p \text {-nitrofenil- } \beta \text {-D-galactopiranosídeo } \\ p \text { NP-Glu } & p \text {-nitrofenil- } \beta \text {-D-glucopiranosídeo } \\ p \text { NP- } \alpha \text { Xil } & p \text {-nitrofenil- } \alpha \text {-D-xilopiranosídeo } \\ \text { rpm } & \text { rotações por minuto } \\ \text { s } & \text { segundo } \\ \text { SDS } & \text { dodecil sulfato de sódio } \\ \text { SDS-PAGE } & \text { eletroforese em gel de poliacrilamida contendo dodecil sulfato de } \\ \text { t } & \text { sódio } \\ \text { TAE } & \text { tempo } \\ \text { TCA } & \text { tris-acetato-EDTA } \\ \text { TLC } & \text { ácido tricloroacético } \\ \text { Tris } & \text { thin-layer chromatography (cromatografia em camada delgada) } \\ \text { YNB } & \text { tris (hidroximetil) aminometano } \\ \text { YPD } & \text { yeast nitrogen base } \\ \end{array}$




\section{SUMÁRIO}

1.1 Biomassa Lignocelulósica e Produção de Etanol de Segunda Geração ................ 22

1.2 Sacarificação da biomassa lignocelulósica..................................................... 27

1.3 Enzimas que atuam sobre xiloglucano ...................................................... 28

$1.4 \quad$ Enzimas empregadas neste trabalho......................................................... 32

Imobilização e Engenharia de Proteínas ........................................................... 36

1.6 Sistemas catalíticos biomiméticos............................................................ 38

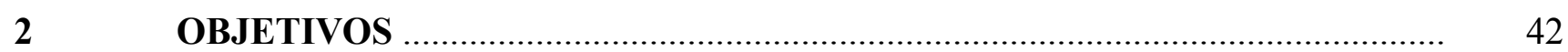

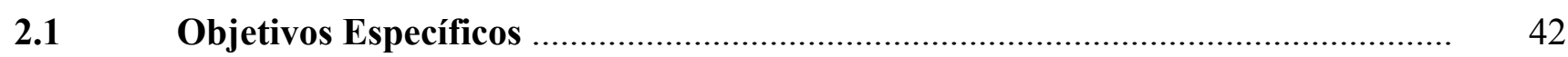

CAPÍTULO I

I. Expressão heteróloga das enzimas com cauda de histidina para imobilização

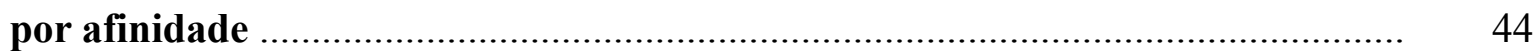

MATERIAIS E MÉTODOS _.......................................................................... 44

$1.1 \quad$ Expressão de XegA e YicI em Escherichia coli ................................................. 44

1.2 Purificação de XegA e YicI por cromatografia de afinidade ............................... 44

1.3 Expressão de Bga1 em Pichia pastoris ............................................................. 45

1.3.1 Transformação de P. pastoris por eletroporação .................................................... 45

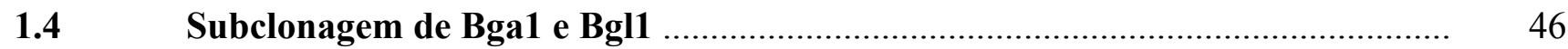

1.4.1 Desenho de oligonucleotídeos iniciadores para subclonagem de Bgal e Bgll via CPEC

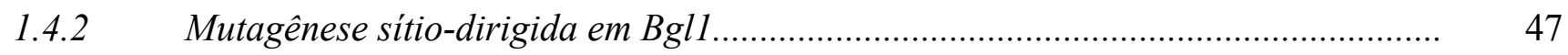

1.4.3 Subclonagem de Bgal e Bgll via CEPEC ............................................................. 48

1.5 Subclonagem de Bga1 e Bgl1 por enzimas de restrição e ligação ........................ 50

1.6 Transformação de células eletrocompetentes de $E$. coli ..................................... 51

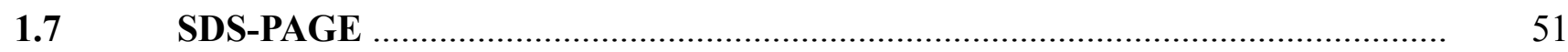

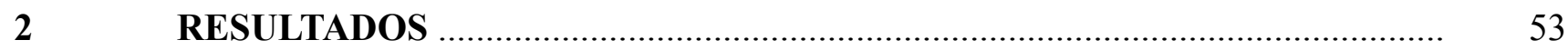

2.1 Expressão e Purificação XegA e YicI ................................................................ 53

2.2 Transformação de Pichia pastoris por eletroporação …..................................... 54

2.3 Mutagênese sítio-dirigida de Bgl1 .................................................................. 55

2.4 Subclonagem de Bga1 e Bgl1 via CPEC ........................................................ 56

2.5 Subclonagem via enzimas de restrição e ligação ............................................... 59 


\section{CAPÍTULO II}

II. Preparação do nanomaterial biomimético via imobilização covalente e caracterização das enzimas livres e imobilizadas .............................................. $\quad 62$

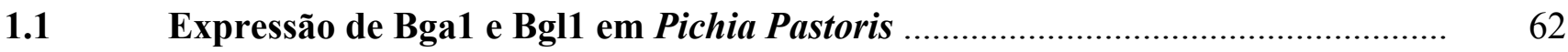

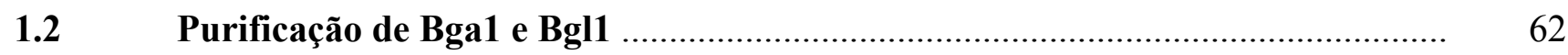

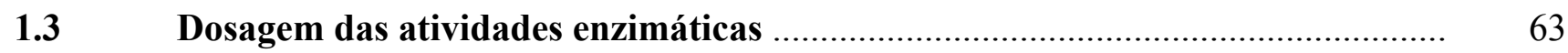

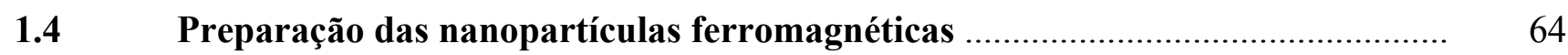

1.5 Preparo do nanomaterial acoplado às enzimas ........................................... 65

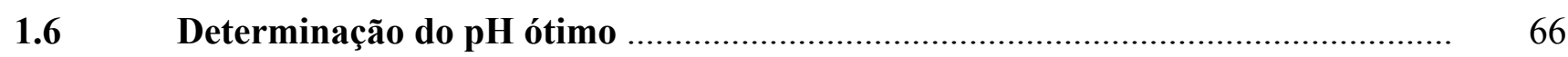

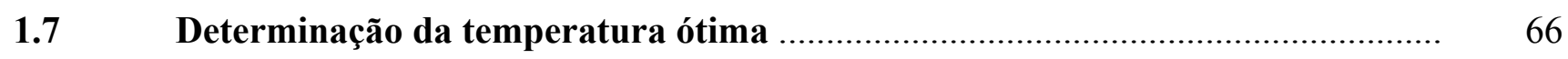

$1.8 \quad$ Estudo de reuso das enzimas imobilizadas ..................................................... 66

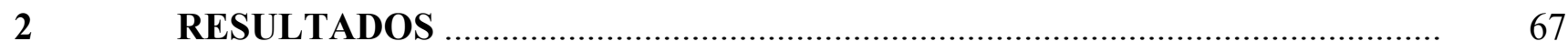

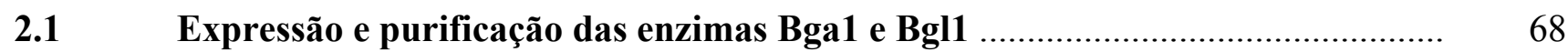

2.2 Caracterização das enzimas livres e imobilizadas: eficiência da imobilização .... 73

2.3 Caracterização das enzimas livres e imobilizadas: efeitos da temperatura ......... 75

2.4 Caracterização das enzimas livres e imobilizadas: efeitos do pH ........................ 78

$2.5 \quad$ Reuso das enzimas imobilizadas ................................................................. 80

CAPÍTULO III

III Estudos de otimização da preparação do sistema nanoestruturado para despolimerização do xiloglucano .................................................................. 84

1.1 Estudo preliminar da imobilização de XegA, YicI, Bga1 e Bgl1 em nanopartículas

1.2 Análise da hidrólise do xiloglucano pelas enzimas imobilizadas no ensaio preliminar por Espectrometria de Massas e TLC

1.3 Estudo de diferentes proporções enzimáticas para otimização da preparação do nanossistema

1.4 Quantificação da hidrólise do xiloglucano pela mensuração de glicose liberada

1.5 Análise da hidrólise do xiloglucano por ESI-MS

1.6 Reuso nos nanossistemas para a hidrólise do xiloglucano .................................... 88

2.1 Estudo preliminar da imobilização covalente de XegA, YicI, Bga1 e Bgl1 e 
análise da degradação do xiloglucano por ESI-MS e TLC

2.2 Estudo da imobilização de diferentes proporções enzimáticas para a hidrólise

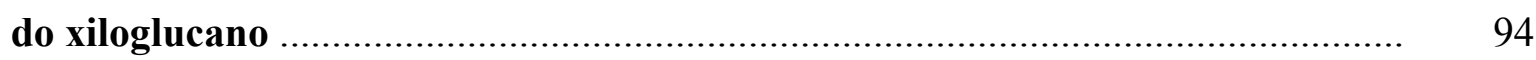

2.3 Análise da hidrólise do xiloglucano por ESI-MS ............................................. 95

2.4 Reuso nos nanossistemas para a hidrólise do xiloglucano .................................. 97

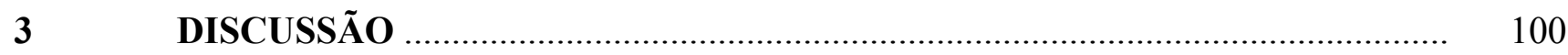

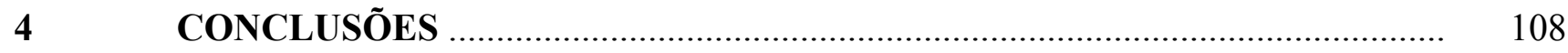

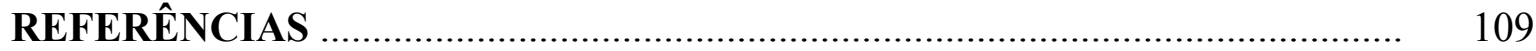

ANEXO A - Sequência do gene yicI e sequência da proteína YicI........................ 116

ANEXO B - Sequência do gene xega e sequência da proteína XegA …............... 117

ANEXO C - Sequência do gene bga1 e sequência transcrita da proteína Bga1... 118

ANEXO D - Sequência do gene bgl1 e sequência transcrita da proteína Bgl1..... 120 
INTRODUÇÃO 


\section{INTRODUÇÃO}

\subsection{Biomassa lignocelulósica e Produção de Etanol de Segunda Geração}

Nas últimas décadas vem crescendo o apelo para a substituição do uso de combustíveis fósseis por energias renováveis, tais como biocombustíveis. $\mathrm{O}$ etanol $\left(\mathrm{C}_{2} \mathrm{H}_{5} \mathrm{OH}\right)$, é um dos biocombustíveis mais produzidos no mundo e é considerado uma das principais alternativas aos combustíveis fósseis por ser uma fonte renovável de energia que contribuiria para a redução das emissões de $\mathrm{CO}_{2}$ no planeta (DE OLIVEIRA; VAUGHAN; RYKIEL, 2005). Também chamado de bioetanol, este combustível pode ser produzido a partir de diferentes fontes, incluindo açúcares simples como a sacarose, amido e biomassas lignocelulósicas. O etanol de primeira geração é derivado da fermentação alcoólica da sacarose e o etanol de segunda geração (2G) é derivado da fermentação de açúcares presentes em materiais linocelulósicos. O Brasil é o maior exportador mundial de bioetanol e segundo maior produtor, atrás apenas dos Estados Unidos. A maior parte do etanol produzido no Brasil é derivado da cana-de-açúcar e nos Estados Unidos, do milho (BALAT, 2011; BALAT; BALAT, 2009).

As metas de redução de emissões de gases de efeito estufa, definidas e aprovadas por muitos países como no Acordo de Paris e em políticas de estado como a RenovaBio - a qual determinou a redução dos gases em 10\% até 2028 no Brasil (LINDNER et al., 2018; MINISTÉRIO DO MEIO AMBIENTE, [s.d.]), tendem a estimular a produção de etanol, que deverá atingir 47 bilhões de litros em 2030 (UNICA, 2018). Neste cenário, inovações tecnológicas relacionadas à produção de etanol, como o desenvolvimento de novas variedades de cana, incluindo a transgênica e a produção de etanol de segunda geração ganham bastante relevância.

Os biocombustíveis de segunda geração foram um dos temas mais discutidos no Brazilian BioEnergy Science and Technology Conference (BBEST) 2017, evento promovido pelo BIOEN, Programa FAPESP de Pesquisa em Bioenergia (ALISSON, 2017). O etanol celulósico ou etanol de segunda geração é principalmente obtido da palha e do bagaço da cana-de-açúcar. Segundo avaliações do Laboratório Nacional de Ciência e Tecnologia do Bioetanol (CTBE), do Centro Nacional de Pesquisa em Engenharia e Materiais (CNPEM), poderá ser economicamente viável a partir de 2025 se forem transpostas as atuais barreiras agrícolas, industriais e tecnológicas para produzi-lo e se o setor sucroenergético brasileiro superar a estagnação em que se encontra. Isso porque acredita-se que, em 2025, o custo de produção do etanol $2 \mathrm{G}$ seja competitivo com o de primeira geração e a partir de 2030, o etanol 2G seja mais barato que o de primeira geração (MILANEZ et al., 2015; UNICA, 2017). Segundo relatório desenvolvido pelo BNDES, as 
inciativas em relação ao etanol $2 \mathrm{G}$ podem significar um aumento de até $50 \%$ em relação ao nível atual no Brasil e abrem também as possibilidades para o uso de uma nova geração de biomassas mais produtivas, com maior conteúdo de fibras (MILANEZ et al., 2015).

Os materiais lignocelulósicos representam boa parte dos compostos orgânicos disponíveis na biosfera. Esse termo designa toda a biomassa vegetal que forma a parede celular, constituída pelas matrizes de celulose, hemicelulose, pectina e lignina (BON; GÍRIO; PEREIRA, 2008; SARKO, 1997). Dentre as matérias-primas disponíveis para produção de energia atualmente, a biomassa celulósica figura entre as matérias primas mais econômicas e a sua vantagem sobre outras é ainda maior quando levada em consideração a questão do sequestro de carbono (LYND et al., 2008). Isso significa que, além de constituir uma fonte de energia renovável, essa biomassa contribuiu para a transferência de $\mathrm{CO}_{2}$ atmosférico para reservatórios biológicos, representando uma forma biótica de sequestro de carbono (LAL, 2008). A biomassa lignocelulósica, portanto, é uma fonte renovável de carbono e energia, oferecendo matéria prima para produção de diversos açúcares que, além de serem convertidos a biocombustíveis como etanol e butanol, também podem ser bioquimicamente transformados em metabólitos de alto valor agregado com ácido lático, ácido succínico, entre outros (MENON; RAO, 2012).

Apesar das características vantajosas da biomassa celulósica como matéria-prima bioenergética já serem bem conhecidas, sobretudo o baixo custo, quando se considera a produção de etanol por fermentação deve-se levar em conta o custo adicional relacionado à necessidade de tornar os açúcares ali presentes acessíveis e fermentáveis. Por exemplo, a produção de etanol de primeira geração tem como base, majoritariamente, vegetais dos quais o açúcar é facilmente extraído, como cana-de-açúcar e milho. O custo de processamento do milho para liberação de açúcar, por exemplo, é bem menor que o custo da conversão da biomassa celulósica em açúcar, que pode chegar ao dobro do valor do processamento do milho, eliminando a vantagem inicial do preço da biomassa celulósica em relação a outras matérias-primas. Assim, o alto potencial de geração de energia em larga-escala dessa biomassa, só poderá ser realmente aproveitado, quando os açúcares produzidos a partir dela alcançarem preços competitivos (LYND et al., 2008).

Interessantemente, resíduos agroindustriais são uma abundante e importante fonte de biomassa lignocelulósica, destacando-se o bagaço e a palha de cana, sabugo e palha de milho, palha e cascas de trigo e arroz, cascas de soja, cascas de coco e resíduos de madeira processada e papel. Dentre estes, os resíduos de cana de açúcar, tanto a palha quanto o bagaço, são os que oferecem maior potencial de produção de etanol a partir de celulose e hemicelulose (ROCHA; ALMEIDA; DA CRUZ, 2017). O bagaço de cana é o resíduo agrícola mais abundante no Brasil e representa uma potencial fonte para etanol de segunda geração, por ser uma biomassa rica em polissacarídeos 
hidrolisáveis (UNICA, 2017 ; ROCHA et al., 2013). A produção de cana de açúcar no Brasil foi de aproximadamente 670 mil toneladas em 2016 (UNICA, 2017), e cada tonelada de cana processada gera cerca de $140 \mathrm{~kg}$ de palha e $140 \mathrm{~kg}$ de bagaço em base seca (PIPPO et al., 2011). Há evidências que a produção de etanol de segunda geração é incrementada quando todos os resíduos de cana-deaçúcar (bagaço, palha, pontas) são aproveitados (PEREIRA et al., 2015).

Segundo um estudo realizado pela Conferência das Nações Unidas para o Comércio e Desenvolvimento (UNCTAD) em 2016, o Brasil tem potencial para produzir até 10 bilhões de litros de etanol 2G até 2025. Entretanto, isso só ocorrerá mediante expansão na moagem de cana, modernização e integração das produções de etanol de primeira e de segunda geração nas usinas já existentes, além da construção anual de 10 unidades exclusivamente voltadas ao biocombustível celulósico a partir de 2020 (UNCTAD, 2016). Atualmente no Brasil há duas usinas de fabricação exclusiva do etanol 2G. Construídas em 2014 e 2015 nas cidades de São Miguel dos Campos (AL) e Piracicaba (SP) pelo Grupo Granbio e Raízen, respectivamente, as unidades têm capacidade de produzir, juntas, até 122 milhões de litros de 2G por ano (UNICA, 2016). Na Romênia, a primeira planta industrial para produção de etanol celulósico exclusivamente a partir de resíduos agrícolas comprova a viabilidade dos biocombustíveis $2 \mathrm{G}$. A fábrica, da empresa Clariant, deve entrar em operação em 2020 e terá capacidade para produzir 62 milhões de litros de biocombustível anualmente (UNICA, 2018).

Além da cana-de-açúcar, outros resíduos agroindustriais também possuem alto potencial energético no Brasil, como palha e sabugo de milho, casca de arroz e soja e coco e palha de trigo. O estudo de Rocha e colegas (2017), analisou o potencial de produção de etanol $2 \mathrm{G}$ a partir da celulose e hemicelulose presente nesses resíduos. Para todos os resíduos avaliados, a celulose é o componente presente em maior quantidade o que demonstra o potencial de produção do etanol $2 \mathrm{G}$, visto que esse polímero é o de maior interesse e que pode ser convertido a açúcares fermentescíveis após as etapas de pré-tratamento e hidrólise. No entanto, também notou-se que para a maioria dos resíduos, a hemicelulose é o segundo componente mais abundante (exceção apenas para a casca do arroz e do coco que apresentam nessa posição a lignina), o que é interessante pois as hemiceluloses são heteropolissacarídeos que também podem ser submetidos às etapas adequadas para obtenção do etanol 2G. As tabelas seguir relacionam o potencial de produção de etanol a partir de celulose (Tabela 1) ou hemicelulose (Tabela 2) para cada resíduo. 
Tabela 1. Potencial de produção de etanol a partir da celulose presente nos resíduos de cada cultura.

\begin{tabular}{|c|c|c|c|c|c|}
\hline Resíduo & $\begin{array}{l}\text { Teor de } \\
\text { celulose por } \\
\text { tonelada de } \\
\text { resíduo }(\%)\end{array}$ & $\begin{array}{c}\text { Glicose } \\
\text { obtida a } \\
\text { partir da } \\
\text { hidrólise da } \\
\text { celulose }^{1} \\
(\mathrm{Kg})\end{array}$ & $\begin{array}{c}\text { Etanol } \\
\text { obtido a } \\
\text { partir da } \\
\text { fermentação } \\
\text { de glicose } \\
\text { (Kg) }\end{array}$ & $\begin{array}{l}\text { Volume de } \\
\text { etanol por } \\
\text { tonelada } \\
\text { de resíduo } \\
\text { (L) }\end{array}$ & $\begin{array}{l}\text { Volume de } \\
\text { etanol por } \\
\text { hectare de } \\
\text { biomassa } \\
\text { (L) }\end{array}$ \\
\hline $\begin{array}{l}\text { Palha de } \\
\text { Milho }\end{array}$ & 36,7 & 293,57 & 135,01 & 170,9 & 503,65 \\
\hline $\begin{array}{l}\text { Sabugo de } \\
\text { Milho }\end{array}$ & 35,4 & 283,17 & 130,23 & 164,85 & 124,92 \\
\hline $\begin{array}{c}\text { Casca de } \\
\text { Arroz }\end{array}$ & 34,0 & 271,97 & 125,08 & 158,33 & 183,92 \\
\hline $\begin{array}{c}\text { Casca de } \\
\text { Soja }\end{array}$ & 35,8 & 286,37 & 131,7 & 166,71 & 38,28 \\
\hline $\begin{array}{c}\text { Palha de } \\
\text { Trigo }\end{array}$ & 35,1 & 280,77 & 129,13 & 163,45 & 653,55 \\
\hline $\begin{array}{l}\text { Palha de } \\
\text { Cana-de- } \\
\text { açúcar }\end{array}$ & 44,3 & 354,36 & 162,97 & 206,29 & 2194,10 \\
\hline $\begin{array}{l}\text { Bagaço de } \\
\text { Cana-de- } \\
\text { açúcar }\end{array}$ & 38,8 & 310,37 & 142,74 & 180,68 & 1921,70 \\
\hline $\begin{array}{c}\text { Casca de } \\
\text { Coco }\end{array}$ & 41,0 & 327,97 & 150,83 & 190,93 & 2426,20 \\
\hline
\end{tabular}

1: $1,11 \mathrm{~g} / \mathrm{g}$; assumindo $80 \%$ de eficiência no pré-tratamento e $90 \%$ de eficiência na hidrólise; $2: \mathrm{Y}_{\mathrm{p} / \mathrm{s}}: 0,51 \mathrm{~g} / \mathrm{g}$ : assumindo $90 \%$ de eficiência na fermentação; 3: densidade do etanol 0,79

Fonte: (ROCHA; ALMEIDA; DA CRUZ, 2017) 
Tabela 2. Potencial de produção de etanol a partir da hemicelulose presente nos resíduos de cada cultura.

\begin{tabular}{|c|c|c|c|c|c|}
\hline Resíduo & $\begin{array}{c}\text { Teor de } \\
\text { Hemicelulose } \\
\text { por tonelada } \\
\text { de resíduo } \\
(\%)\end{array}$ & $\begin{array}{l}\text { Xilose obtida } \\
\text { a partir da } \\
\text { hidrólise da } \\
\text { hemicelulose }^{1} \\
\text { (Kg) }\end{array}$ & $\begin{array}{c}\text { Etanol } \\
\text { obtido a } \\
\text { partir da } \\
\text { fermentação } \\
\text { de xilose }^{2} \\
(\mathrm{Kg})\end{array}$ & $\begin{array}{l}\text { Volume de } \\
\text { etanol por } \\
\text { tonelada } \\
\text { de resíduo } \\
\text { (L) }\end{array}$ & $\begin{array}{l}\text { Volume de } \\
\text { etanol por } \\
\text { hectare de } \\
\text { biomassa } \\
\text { (L) }\end{array}$ \\
\hline $\begin{array}{c}\text { Palha de } \\
\text { Milho }\end{array}$ & 34,2 & 279,73 & 71,47 & 90,47 & 266,61 \\
\hline $\begin{array}{l}\text { Sabugo de } \\
\text { Milho }\end{array}$ & 26,9 & 220,02 & 56,22 & 71,16 & 53,92 \\
\hline $\begin{array}{c}\text { Casca de } \\
\text { Arroz }\end{array}$ & 13 & 106,33 & 27,17 & 34,39 & 39,95 \\
\hline $\begin{array}{c}\text { Casca de } \\
\text { Soja }\end{array}$ & 23,1 & 188,94 & 48,27 & 61,11 & 14,03 \\
\hline $\begin{array}{c}\text { Palha de } \\
\text { Trigo }\end{array}$ & 19,8 & 161,95 & 41,38 & 52,38 & 209,42 \\
\hline $\begin{array}{l}\text { Palha de } \\
\text { Cana-de- } \\
\text { açúcar }\end{array}$ & 31,1 & 254,37 & 64,99 & 82,27 & 874,99 \\
\hline $\begin{array}{l}\text { Bagaço de } \\
\text { Cana-de- } \\
\text { açúcar }\end{array}$ & 29,4 & 240,47 & 61,44 & 77,77 & 827,16 \\
\hline $\begin{array}{c}\text { Casca de } \\
\text { Coco }\end{array}$ & 21,5 & 175,85 & 44,93 & 56,87 & 722,73 \\
\hline
\end{tabular}

1: $1,11 \mathrm{~g} / \mathrm{g}$; assumindo $80 \%$ de eficiência no pré-tratamento e $90 \%$ de eficiência na hidrólise; $2: \mathrm{Y}_{\mathrm{p} / \mathrm{s}}: 0,51 \mathrm{~g} / \mathrm{g}$ : assumindo 50\% de eficiência na fermentação; 3: densidade do etanol 0,79

Fonte: (ROCHA; ALMEIDA; DA CRUZ, 2017)

A utilização efetiva de materiais lignocelulósicos em processos biotecnológicos é dificultada pela associação celulose-hemicelulose-lignina, uma barreira natural à degradação enzimática e microbiana desses materiais e à estrutura cristalina da celulose, a qual é muito resistente à hidrólise. Além disso, existem as exigências de alta temperatura e pressão para o procedimento de hidrólise ácida da celulose, além dos resíduos tóxicos gerados (JACOBSEN; WYMAN, 2000). Ainda, devido à arquitetura complexa de parede celular, diferentes tipos de plantas podem necessitar de métodos de despolimerização completamente diferentes (LYND et al., 2002). Dessa forma, um dos grandes desafios para a produção de etanol de segunda geração é o desenvolvimento de tecnologias de pré-tratamento eficazes, que favoreçam a obtenção de açúcares para a fermentação alcoólica. Uma tendência que vai ao encontro desses objetivos é o desenvolvimento de formulações 
inteligentes de enzimas para a hidrólise eficiente da biomassa lignocelulósica (BON; GÍRIO; PEREIRA, 2008)

As principais etapas para a produção de etanol $2 \mathrm{G}$ envolvem pré-tratamento, hidrólise e fermentação. Como já foi mencionado, uma vez que a estrutura da biomassa lignocelulósica é bastante complexa e de difícil acesso aos microorganismos fermentadores, a etapa de pré tratamento tem como função a desestruturação dessas barreiras, facilitando o acesso aos polissacarídeos. Em seguida, a etapa de sacarificação, que pode ser ácida ou enzimática promove a conversão de polissacarídeos a açúcares fermentescíveis os quais serão, por sua vez, convertidos à etanol pelo processo de fermentação. Existem evidências de que, na etapa de sacarificação, a hidrólise enzimática é mais vantajosa pois é muito mais específica e elimina a formação de inibidores do processo fermentativo (PEREIRA et al., 2015; ROCHA; ALMEIDA; DA CRUZ, 2017).

Para a hidrólise enzimática são empregados os chamados coquetéis enzimáticos, contendo as enzimas necessárias para despolimerização dos polissacarídeos presentes na biomassa. Os principais coquetéis comercias atualmente incluem o Cellic CTec e a Celluclast 1,5 (Novozymes), produzidos a partir de fungos e suplementados com outras atividades, produzidas em sistemas recombinantes, com o objetivo de se obter formulações otimizadas cada vez mais eficientes (BUSSAMRA, 2014). É o alto custo da hidrólise enzimática, na etapa de sacarificação, que atualmente limita a produção de etanol a partir de biomassa lignoscelulósica. Por isso, o desenvolvimento de tecnologias que tornem a hidrólise de biomassa efetivamente mais barata, é o um dos principais desafios a serem superados.

\subsection{Sacarificação da biomassa lignocelulósica}

O principal carboidrato da parede vegetal, a celulose, é encontrada em uma matriz complexa, associada à hemicelulose e lignina, constituindo o resíduo polimérico predominante da atividade agrícola (HARRIS; DEBOLT, 2010). Tal matriz dificulta o acesso de celulases ao seu substrato pois as hemiceluloses são formadas por uma diversidade de polissacarídeos que revestem as microfibrilas de celulose e as mantêm unidas às microfibrilas adjacentes, contribuindo, assim, para umas estrutura resistente de suporte da parede celular. Os principais polissacarídeos presentes na hemicelulose são $\beta$-glucano, xilano, xiloglucano, arabinoxilano, manano, galactomanano, arabinano, galactano e poligalacturonano. Xilano é o polissacarídeo hemicelulósico mais predominante na parede celular secundária de dicotiledôneas, enquanto o xiloglucano é o polissacarídeo hemicelulósico predominante na parede primária. (DUPREE et al., 2015; SWEENEY; XU, 2012). 
Para a sacarificação da celulose é necessária a ação sinérgica de pelo menos três diferentes classes de enzimas, que compõem o chamado "complexo celulolítico". Estas classes correspondem às endo-1,4-ß-glucanases (EC 3.2.1.4), exo-1,4-ß-glucanases (EC 3.2.1.91) e 1,4-ß-glucosidases (EC 3.2.1.21) (HARRIS; DEBOLT, 2010; KUMAR; SINGH; SINGH, 2008; LYND et al., 2002). Uma estratégia para a hidrólise enzimática da biomassa proveniente de cana-de-açúcar foi proposta por Souza et al. (2003). A estratégia é um modelo de hidrólise hierárquica, utilizando prétratamentos da biomassa com enzimas pectinases e posteriormente com uma mistura de enzimas capaz de hidrolisar as cadeias laterais e principais da estrutura remanescente de celulose interligada a xiloglucano e arabinoxilano. Após esses pré-tratamentos enzimáticos a celulose remanescente estaria disponível para o ataque enzimático por endo- $\beta$-glucanase, celobiohidrolases e $\beta$ glicosidases (DE SOUZA et al., 2013).

Utilizando esta lógica, sabendo-se a constituição de outros polímeros, como o xiloglucano, é possível determinar o modelo de hidrólise hierárquica para sua degradação. Para isso, o desenvolvimento de combinações enzimáticas específicas representa uma alternativa promissora para a hidrólise completa dos polissacarídeos da parede celular.

\subsection{Enzimas que atuam sobre xiloglucano}

O xiloglucano é um polissacarídeo hemicelulósico que contribui para a complexa rede de polissacarídeos presente na parede celular vegetal, mantendo as microfibrilas de celulose unidas. (BUCKERIDGE, 2010). É o componente hemicelulósico mais abundante nas paredes celulares primárias das dicotiledôneas e também presente em quase metade de todas as espécies monocotiledôneas. Os xiloglucanos são constituídos por um esqueleto $\beta$-1-4-D-glucano no qual até 75\% dos resíduos de glicose são substituídos na posição O6 com cadeias laterais mono-, di- ou triglicosídicas (BENKÖ et al., 2008; FURTADO et al., 2015).

Antes apontado como componente apenas de vegetais terrestres, o xiloglucano é encontrado em inúmeras espécies, inclusive em algas verdes, onde foram identificados genes relacionados à síntese e degradação do xiloglucano. Em estudos recentes, tem sido atribuído ao xiloglucano um papel na adaptação de algas verdes à ocupação terrestre. Uma evidência apontada por essa teoria foi a descoberta de uma função totalmente nova do xiloglucano, como um potente agregador de solo, sendo liberado pelas raízes ou rizóides de todos os principais grupos de plantas terrestres (DELBEM, 2018). 
A estrutura básica do xiloglucano é composta por uma cadeia principal de unidades de glicose unidas por ligações $\beta$ - $(1,4)$ com ramificações regulares de resíduos de xilose ligados por ligações $\alpha$ $(1,6)$. A estes resíduos de xilose podem estar ligados resíduos de galactose unidos por ligações $\beta$ $(1,2)$ (BUCKERIDGE, 2010). Em vários tipos de xiloglucano, resíduos de fucose estão presentes ligados aos resíduos de galactose por ligações $\alpha$-(1,2). Entretanto, no xiloglucano de reserva de sementes como as de jatobá (Hymenaea courbaril), as ramificações com resíduos de fucosidase não estão presentes (TINÉ; CORTELAZZO; BUCKERIDGE, 2000). A Figura 1 traz uma representação da estrutura do xiloglucano de reserva.

Asim, pode-se concluir que para a liberação de monossacarídeos a partir dos oligômeros do xiloglucano é necessária a ação combinada entre as enzimas: endo- $\beta$-1,4-glucanase - específica para xiloglucano (EC 3.2.1.151), $\beta$-galactosidase (EC 3.2.1.23), $\alpha$-xilosidase (EC 3.2.1.177) e $\beta$ glucosidase (EC 3.2.1.21). O polissacarídeo de xiloglucano é primeiramente hidrolizado pela endo$\beta$-1,4-glucanase, que cliva sítios internos da cadeia principal, originando oligossacarídeos os quais são hidrolisados pela $\beta$-galactosidase, liberando os monômeros de galactose que estavam presentes em ramificações. Da mesma forma, os oligossacaríedos remanescentes têm seus resíduos xilosil removidos pela ação da $\alpha$-xilosidase. A partir daí, a $\beta$-glucosidase poderá mobilizar os resíduos de glicose a partir da cadeia principal (Figura 1) (KOYAMA et al., 1983; TINÉ; CORTELAZZO; BUCKERIDGE, 2000). 

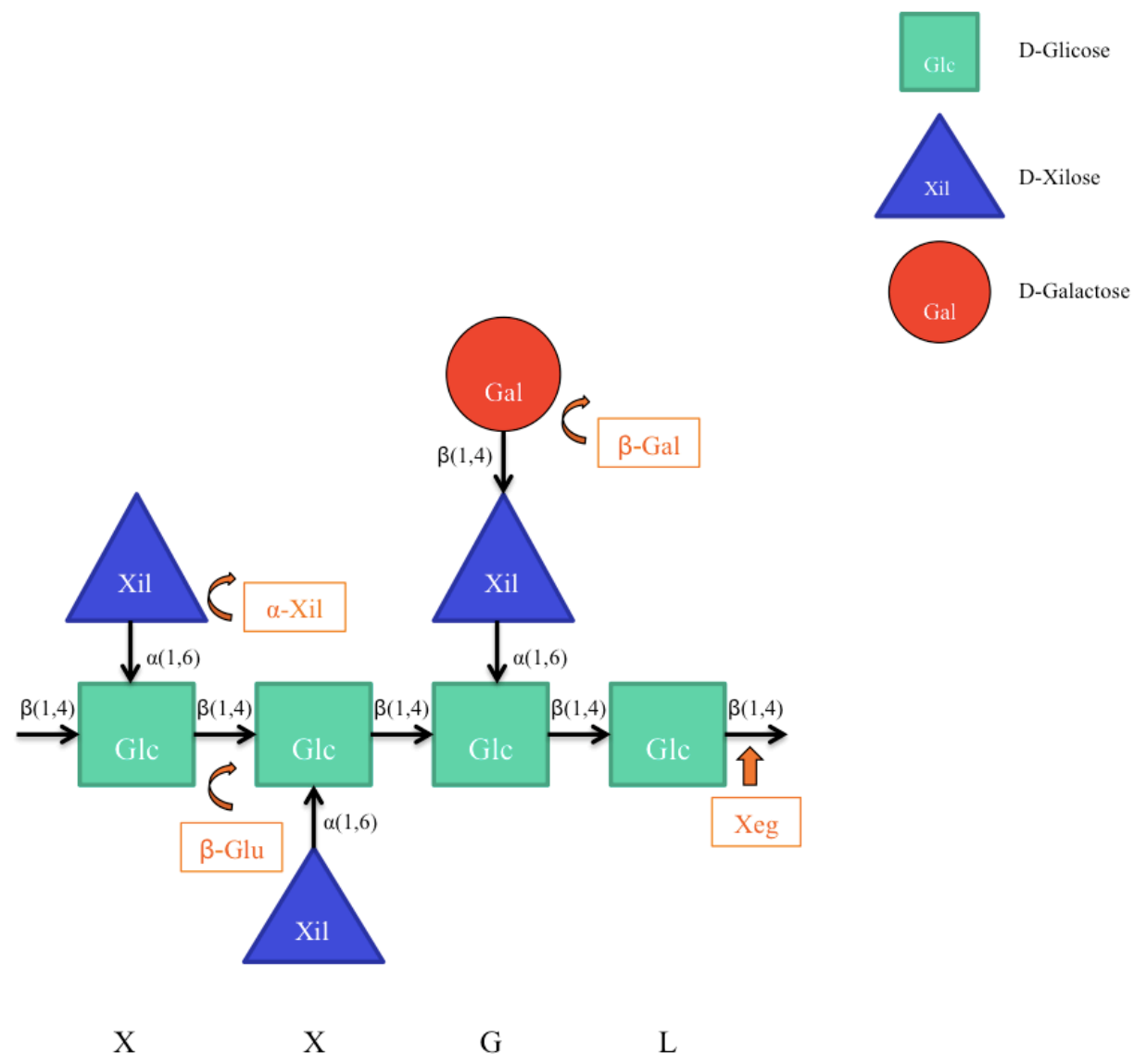

Figura 1. Representação da estrutura do xiloglucano de reserva, incluindo os tipos de ligações entre os açúcares da cadeia principal e os resíduos que fazem ramificações. Também estão assinalados os quatro tipos de enzimas necessários para a degradação total de xiloglucano próximas às respectivas ligações sobre as quais atuam: endoxilogucanases (Xeg), $\beta$-galactosidase ( $\beta$-Gal); $\alpha$-xilosidase ( $\alpha$-Xil) e exo- $\beta$-glucosidase ( $\beta$-Glu). Na parte de baixo da figura, a abreviação que é comumente usada para oligossacarídeos derivados de xiloglucano, X para resíduos com ramificação de xilose, G para resíduos com ramificação de galactose e L para resíduos de glicose não substituídos.

Fonte: elaborado pela autora

Por ser um dos principais componentes da parede celular primária de plantas, a degradação enzimática dos polímeros de xiloglucano por xiloglucanases pode melhorar a hidrólise total de biomassas lignocelulósicas, assim permitindo que celulases atuem hidrolisando os polímeros de celulose mais eficientemente. Em um estudo, a aplicação de endoglucanses, xiloglucanases e $\beta$ glucosidases provenientes de fungos, entre outras enzimas celulásicas, contribuiu para aumentar a hidrólise total de substratos lignocelulósicos (BENKÖ et al., 2008).

Os estudos recentes em hidrólise de biomassas revelam uma tendência ao desenvolvimento de microrganismos transgênicos capazes de produzir todas as enzimas hidrolíticas necessárias para a conversão eficiente da biomassa, como uma forma de redução de custos do bioprocesso. Inclusive, 
o desenvolvimento de microrganismos hiperprodutores de hidrolases de xiloglucano são uma aposta para o desenvolvimento de coquetéis celulolíticos mais eficientes no futuro. Enquanto isso, alguns estudos têm investido na engenharia de proteínas para o melhoramento de enzimas xiloglucanases, por exemplo, desenvolvendo quimeras pela fusão de xiloglucanases a CBMs (Carbohydrate binding domain) específicos de xiloglucanos, no intuito de aumentar a o reconhecimento e ligação da enzima ao substrato (FURTADO et al., 2015; GUPTA, 2016).

Para este trabalho, propôs-se a utilização das enzimas endo- $\beta(1,4)$ glucano hidrolase de Aspergillus niveus (XegA), $\beta$-galactosidase de Thicchoderma reesei (Bga1), $\alpha$-xilosidase de Escherichia coli (YicI) e exo- $\beta$-glucosidase de Thicchoderma reesei (Bgl1) para a despolimerização do xiloglucano. 


\subsection{Enzimas empregadas neste trabalho}

A enzima endo- $\beta(1,4)$ glucano hidrolase de Aspergillus niveus - XegA é uma enzima endoglucanase que demonstra especificidade por xiloglucano. Xiloglucanases já foram identificadas nas famílias GH 5, 12, 64, 44 e 74. XegA é da família GH12 e possui uma estrutura compacta numa conformação em forma de $\beta$-jelly roll. Apesar de ser mais ativa em um estado monomérico, dados cristalográficos demonstraram que sua estrutura também forma um arranjo dimérico estável (DAMASIO et al., 2017; FURTADO et al., 2015). O modo de ação de XegA, característico também de outras hidrolases GH12, consiste na hidrólise de ligações glicosídicas $\beta(1,4)$ entre resíduos de glicose não ramificados com xilose (DAMÁSIO et al., 2012). Os coordenados atômicos de XegA encontra-se disponível no banco de dados PDB (Protein Data Bank) sob o código 4NPR (Figura 2).

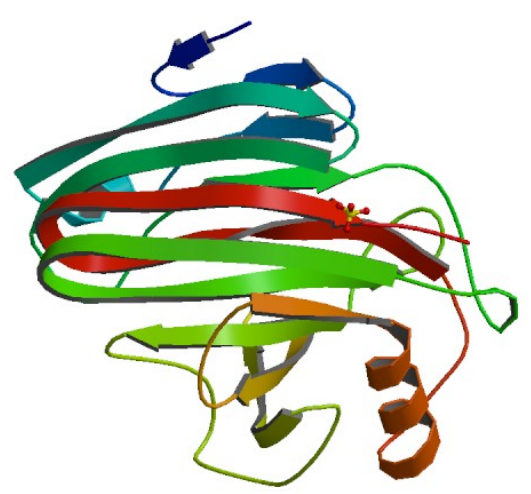

Figura 2. Estrutura tridimensional da enzima XegA. Fonte: PDB

A enzima $\alpha$-xilosidase de Escherichia coli - YicI, possui similaridades com a família GH31 (OKUYAMA et al., 2004). Sua estrutura oligomérica é formada por dois anéis triméricos empilhados. A sua estrutura tridimensional resolvida revelou um domínio catalítico na forma de barril $(\beta / \alpha)_{8}$ (OKUYAMA et al., 2006). Essa estrutura se encontra depositada no PDB sob o código 1XSI (Figura 3). A oligomerização desta enzima provavelmente tem um papel funcional na ligação do substrato (OKUYAMA et al., 2006). Resultados de hidrólise do xiloglucano analisados por espectrometria de massas (ESI-MS/MS) revelaram que YicI tem uma preferência por clivar resíduos de xilose em oligossacarídeos não galactosilados (CARNEIRO, 2017). 

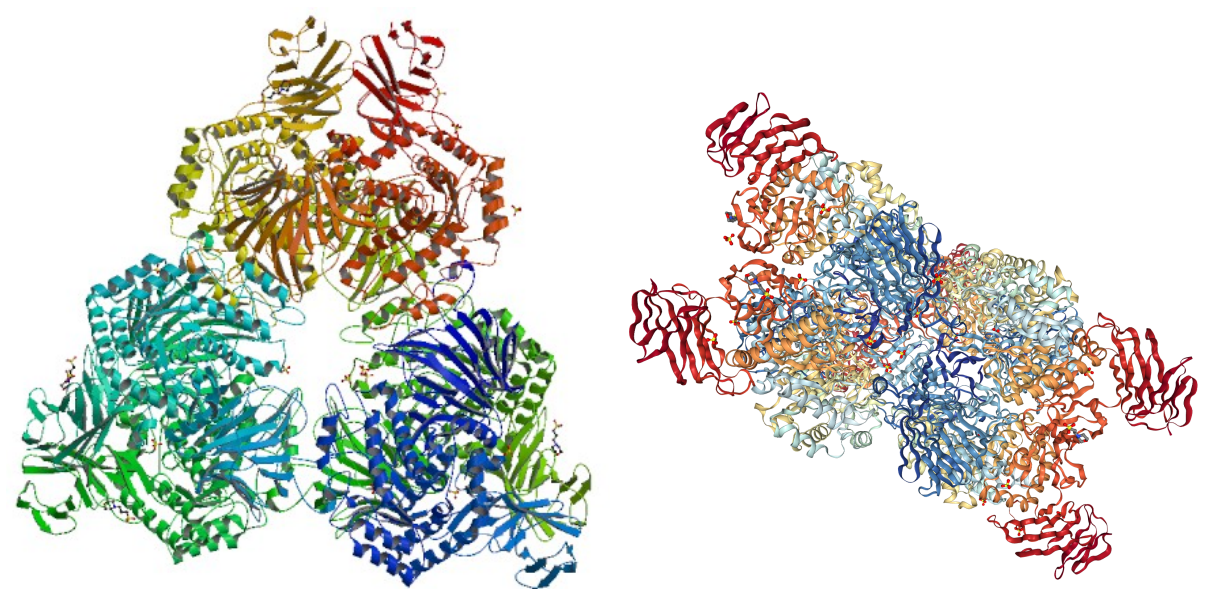

Figura 3. Estrutura tridimensional da enzima YicI, vista frontal (esquerda) e vista lateral (direita), na qual é possível observar os dois anéis triméricos empilhados. Fonte: PDB

A enzima $\beta$-galactosidase - Bga1, foi isolada de Trichoderma reesei (Hypocrea jecorina) pertence à família GH 35 e tem a capacidade de hidrolisar ligações $\beta(1,3)$ e $\beta(1,4)$ galactosil tanto em oligos como em dissacarídeos, liberando monossacarídeos. Além disso, também é capaz de catalizar reações de transglicosilação. Esta enzima, assim comos todo os membros da superfamília GH-A, possui um domínio catalítico do tipo barril $(\beta / \alpha)_{8}$ (MAKSIMAINEN et al., 2011). Os coordenados atômicos da proteína encontram-se depositada no PDB sob o código 3OG2 (Figura 4).

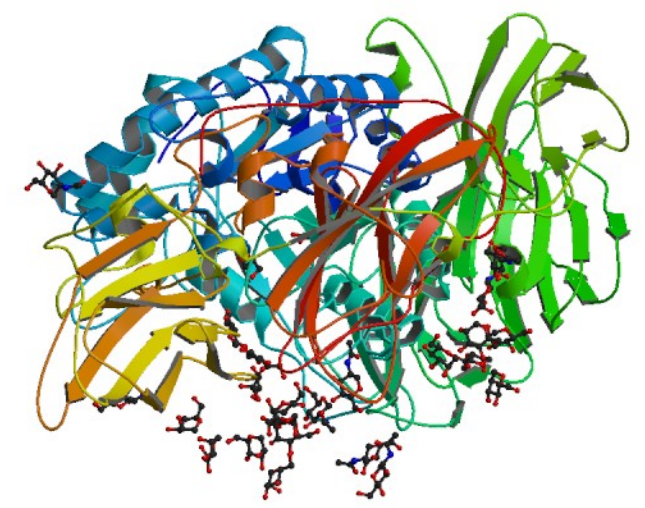

Figura 4. Estrutura tridimensional de Bga1. Fonte: PDB

Enzimas $\beta$-glucosidases fungicas pertencem às famílias $\mathrm{GH} 1$ e GH3, de acordo com o bando de dados CAZy. Do ponto de vista estrutural, as $\beta$-glucosidases apresentam também o domínio barril $(\beta / \alpha)_{8}$ no sitio catalítico e atuam por um mecanismo de retenção utilizando um resíduo glutamato (Glu) no sítio ativo como nucleófilo (TIWARI; MISRA; SANGWAN, 2013), assim como outras hidrolases da superfamília GH-A. A enzima $\beta$-glucosidase de Trichoderma reesei 
(Hypocrea jecorina) - Bgl1, é uma GH3 e catalisa a hidrólise de ligações $\beta$-glicosídicas em dissacarídeos e oligossacarídeos (CHEN et al., 2011). Caracterização bioquímica demonstrou que Bgl1 é capaz de hidrolisar eficientemente ligações $\beta(1,4),(1,3),(1,2)$ e ainda $(1,6)$ em dissacarídeos. Bgll e eficiente em converter tanto celobiose, quanto celoligossacarideos maiores em glicose (KARKEHABADI et al., 2014). Apesar de ser comumente nomeada Bgl1 e seu respectico gene bgl1 (GeneBank AAA18473.1), também é denominda Cel3A (estão classificadas como a mesma proteína no banco de dados CAZy; código de acesso Uniprot Q12715) e os coordenados atômicos são depositados no PDB sob o código 4I8D (Figura 5). No estudo cristalográfico, uma unidade assimétrica continha duas moléculas da proteína. Há evidências de que $\beta$-glucosidases GH3 podem ser homodímeros e requerem dimerização para a catálise (MCANDREW et al., 2013).
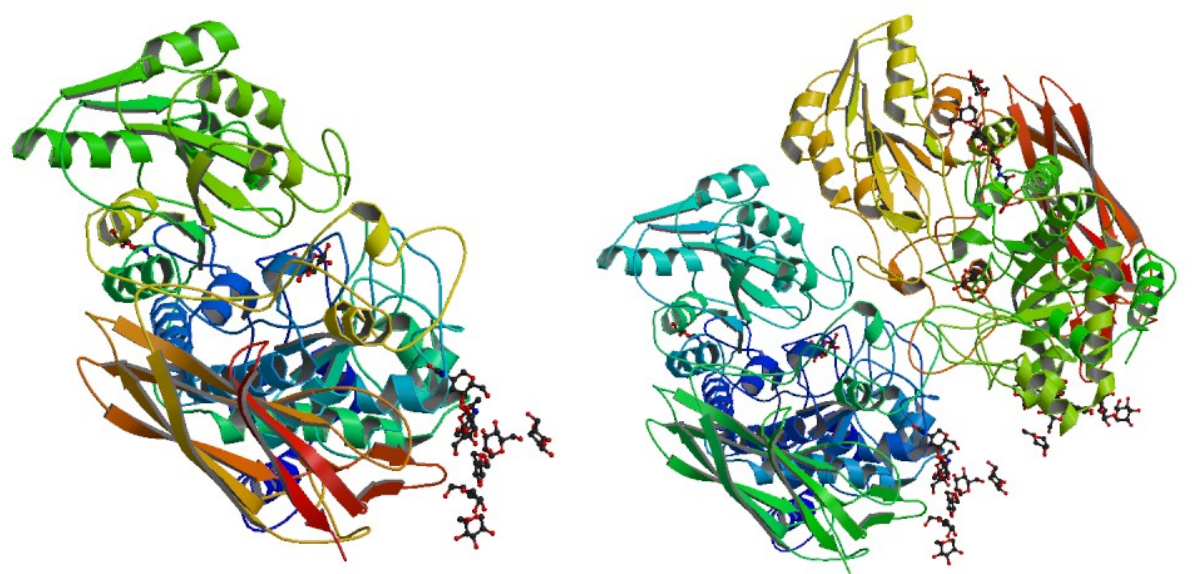

Figura 5. Estrutura tridimensional da enzima Bgl1 (PDB 4I8D). Estrutura tridimensional da enzima Bgl1 (esquerda) e a unidade assimétrica contendo duas moléculas da proteína (direita). Fonte: PDB

Assim, neste trabalho, estudou-se o efeito da imobilização em cada uma das quatro enzimas mencionadas nas nanopartículas magnéticas e a co-localização das quatro enzimas pra a construção de um nanossistema híbrido capaz de despolimerizar o polissacarídeo xiloglucano. Na Figura 6, um esquema da co-imobilização das enzimas nas nanopartículas. 


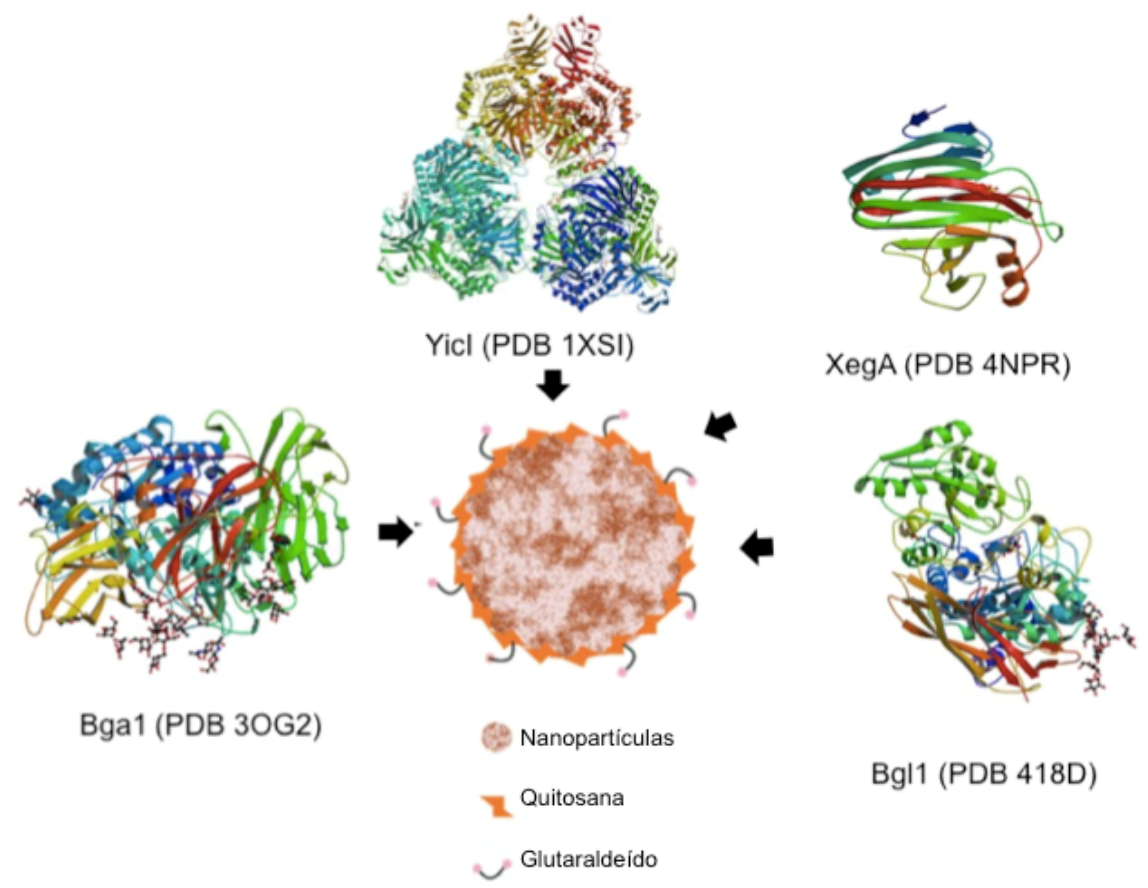

Figura 6. Esquema da co-imobilização covalente das quatro enzimas ativas sobre o xiloglucano nas nanopartículas magnéticas. Fonte: elaborado pela autora 


\subsection{Imobilização e Engenharia de Proteínas}

Um fator limitante na sacarificação tanto de celulose como de hemiceluloses é que, à medida que a hidrólise acontece, a glicose liberada pode causar inibição por produto da enzima $\beta$ glucosidase. A redução da atividade dessa enzima leva ao acúmulo de seu substrato, a celobiose. Por sua vez, altas concentrações de celobiose no meio reacional podem causar a inibição por produto das celobiohidrolases (no caso da celulose) e também das endoglucanases. Para reverter esse quadro, as principais alternativas são adição de mais enzimas à reação, o que resulta em aumento dos custos de produção, ou remoção do açúcar formado. No caso dos processos de sacarificação e fermentação simultâneas, o açúcar formado é removido através da sua fermentação a etanol pelo microorganismo (BUSSAMRA, 2014; LYND et al., 2002; OLSSON et al., 2005). Uma outra solução é a imobilização de enzimas, a qual permite a separação da enzima dos produtos e o seu reuso, consequentemente reduzindo o consumo de enzimas no processo (LEE et al., 2010; SONG et al., 2016).

Enzimas em sua conformação nativa são comumente empregadas na indústria, e por si só, reúnem excelentes propriedades, como alta seletividade e especificidade. Porém o uso de enzimas em catálise e processos metabólicos complexos, a exemplo da produção de etanol de segunda geração, exige que os bioprocessos e as próprias enzimas sejam otimizados de modo a serem mais eficientes. A catálise em processos industriais pode ser regulada em vários níveis e um deles é a imobilização de enzimas, que pode conferir mais estabilidade, durabilidade e desempenho das respectivas enzimas (CASTRO et al., 2008).

A imobilização de enzimas começou a ser estudada no início do século $\mathrm{XX}$, quando se observou que o carvão ativado adicionado a uma preparação biológica com atividade invertásica, mantinha a capacidade de hidrólise de sacarose mesmo após lavagens (NELSON; GRIFFIN, 1916). $\mathrm{Na}$ segunda metade do século, Sumner, bioquímico americano ganhador do Prêmio Nobel de Química em 1946 pelo isolamento e cristalização da urease, reportou a imobilização da mesma enzima em 1948. Logo em seguida, em 1954, pesquisadores alemães demonstraram que polímeros sintéticos poderiam ser usados na imobilização de enzimas (CASTRO et al., 2008; CHIBATA, 1978).

As enzimas podem ser imobilizadas por meios químicos, quando a interação envolvida é uma ligação covalente ou meios físicos, quando as interações envolvem forças físicas como adsorção, interações eletrostáticas, encapsulação, etc. Além disso as enzimas imobilizadas também podem ser divididas em duas categorias principais, sendo elas as enzimas ligadas em suportes, sendo assim 
imóveis, e enzimas solúveis com derivatização, ou seja, que estão ligadas a outras moléculas, mas permanecem em complexos solúveis (CASTRO et al., 2008).

As principais vantagens do uso de enzimas imobilizadas são o aproveitamento da atividade catalítica por um maior período de tempo, a facilidade de separação do catalisador e do produto de reação, facilidade de reutilização da enzima, que em muitos casos continua ativa após vários ciclos de catálise e, em alguns casos, a alteração das propriedades catalíticas da enzima em relação à sua forma solúvel (CASTRO et al., 2008). Por sua vez, imobilização em nanomateriais, também oferece as vantagens adicionais, como o de aumento da concentração local, além de proporcionar maior estabilidade, possibilitando a atuação das enzimas em faixas mais amplas de $\mathrm{pH}$ e temperatura. Ainda, a iniciativa de se utilizar nanomateriais para imobilização de enzimas reúne as propriedades físicas dos nanomateriais de difusão facilitada e grande mobilidade, que podem resultar em aumento da capacidade catalítica das enzimas imobilizadas (ANSARI; HUSAIN, 2012).

Embora a maioria dos estudos até hoje foquem na imobilização de enzimas individualmente, a co-imobilização ou imobilização de múltiplas enzimas recentemente tem atraído a atenção pela capacidade de aumentar a concentração enzimática local e levar a rendimentos maiores (WANG; ZHANG, 2015). A co-imobilização é especialmente útil por ser capaz de acoplar reações que naturalmente ocorrem em sequência, mimetizando o que ocorre dentro de uma célula, por exemplo (BETANCOR; LUCKARIFT, 2010). A grande contribuição da co-localização de múltiplas enzimas para a bionanotecnologia é a capacidade de preservar a atividade enzimática e promover a atividade sinérgica (LIANG et al., 2016). A co-imobilização de múltiplas enzimas, portanto, foi a estratégia considerada neste trabalho, no que diz respeito ao estudo do modelo de hidrólise hierárquica do xiloglucano.

Para aplicação em processos biotecnológicos, é necessário que a técnica de imobilização e a orientação das moléculas de proteínas imobilizadas mantenham a atividade enzimática (RUSMINI; ZHONG; FEIJEN, 2007). Ainda, o suporte escolhido deve ser biocompatível e inerte (ANSARI; HUSAIN, 2012). No caso de nanopartículas magnéticas, esse material confere grande capacidade de ligação e aumento da atividade catalítica da enzima conjugada, devido à grande relação superfície/volume. Além disso o uso de nanopartículas magnéticas favorece a recuperação enzimática ao final do bioprocesso (ANSARI; HUSAIN, 2012; KALKAN et al., 2012; PAN et al., 2009; SONG et al., 2016).

Para este trabalho, foram empregadas as nanopartículas magnéticas produzidas no Laboratório de Bioquímica e Biofísica de Proteínas (LBBP) do Departamento de Química da FFCLRP, Universidade de São Paulo. Esse nanomaterial foi descrito recentemente por Carneiro e Ward (2016), com uma patente registrada sob o nº BR 102016021095-0, e já foi aplicado com 
sucesso na imobilização de uma enzima $\beta$-galactosidase (CARNEIRO; WARD, 2018). O nanocomposto revestido por quitosana e funcionalizado por glutaraldeído, ácido N- (5-amino-1carboxi- pentil) iminodiacético (AB-NTA) e níquel, mostrou-se estável em solução e adequado para imobilizar enzimas, bem como ser aplicado na purificação de proteínas recombinantes que carregam His-tag, substituindo portanto matrizes de afinidade. Ainda, o nanomaterial demonstrou grande utilidade de reuso visto que a enzima imobilizada reteve ainda $80 \%$ da atividade após nove ciclos de lavagens (CARNEIRO; WARD, 2018).

Este nanomaterial, por ser funcionalizado com $\mathrm{Ni}^{2+}$, é capaz de imobilizar e purificar especificamente proteínas que possuam His-tag. Por outro lado, estas nanopartículas também podem ser preparadas sem a adição de AB-NTA e níquel, podendo promover a imobilização inespecífica de proteínas, por meio de ligação covalente promovida pelo glutaraldeído, presente nas partículas. Assim, as nanopartículas empregadas neste trabalho possuem ampla aplicação, podendo imobilizar enzimas de modo específico ou inespecífico, de forma rápida, prática e de baixo custo.

\subsection{Sistemas catalíticos biomiméticos}

No intuito de aperfeiçoar a aplicação de enzimas em processos industriais, otimizando seu desempenho catalítico muitos esforços são concentrados em técnicas de desenho racional ou evolução dirigida de enzimas (BÖTTCHER; BORNSCHEUER, 2010; TANG; ZHAO, 2009; WEN; NAIR; ZHAO, 2009; WOODLEY, 2013). Por outro lado, a fusão dos conhecimentos de biologia molecular às técnicas de engenharia de materiais tem conduzido estudos no campo da biomimética molecular, incluindo o desenho de sistemas moleculares multifuncionais em dispositivos de escala nanométricas (TAMERLER et al., 2010).

Como exemplo de integração entre biologia molecular e engenharia de materiais, recentemente tem se desenvolvido o campo de co-imobilização de enzimas de forma sequencial em microchips, o que permite a criação de sistemas de microreatores. Por exemplo, Fornera e colaboradores (2012) relataram a imobilização sequencial de $\beta$-galactosidase, glicose oxidase e peroxidase em um chip para a condução de uma reação enzimática em cascada. Ainda, um campo da engenharia de materiais que fornece ferramentas promissoras para a imobilização de enzimas é o de impressão 3D. Diversos tipos de materiais podem ser aplicados em impressão 3D, incluindo materiais biológicos como as enzimas. O processo de impressão $3 \mathrm{D}$ de biomateriais permite a construção de estruturas com diferentes morfologias e geometrias pré-projetadas e personalizadas (WŁODARCZYK-BIEGUN; DEL CAMPO, 2017), e portanto no caso da a co-localização de enzimas favorece um maior controle na imobilização e um menor desperdício. Biorreatores para o 
monitoramento de glicose e lactato extracelular nos cérebros de ratos foram construídos com a impressão 3D de baixo custo das enzimas glicose oxidase e lactato oxidase (SU et al., 2016).

Dentro da área de sacarificação de matérias lignocelulósicas, a associação sinérgica de enzimas já foi diversas vezes abordada pelo design de celulossomos, estruturas organizadas onde diversas enzimas como pectinases, celulases e hemicelulases são unidas por meio de uma estrutura não-catalítica. No entanto, a construção de um celulossomo é laboriosa e tem um custo elevado (WEN; NAIR; ZHAO, 2009). Apesar disso, há evidências que a proximidade entre as enzimas é um fator chave no efeito sinérgico dos celulossomos (FIEROBE et al., 2002). Por exemplo, a imobilização de enzimas endoglucanase, $\beta$-glucosidase e exoglucanase na superfície de Saccharomyces cerevisiae, revelou melhor atividade da hidrólise de carboximetil celulose (CMC) do que as enzimas livres (FAN et al., 2012).

Portanto, a possibilidade de co-localização via imobilização em nanopartículas, de proteínas que fazem parte da mesma via de metabolização de determinado composto, com grande proximidade em entre seus centros catalíticos, é promissora, no contexto em que suas propriedades podem ser maximizadas devido ao fator de proximidade e a co-imobilização. Alguns estudos reportam com sucesso a co-imobilização e o efeito sinérgico da catálise enzimática em cascada direcionada para hidrólise de celulose. A co-localização de endoglucanase e $\beta$-glucosidase em nanopartículas magnéticas derivadas da bactéria magnetotática Magnetospirillum magneticum, resultou na hidrólise de CMC aumentada, em comparação com uma mistura das enzimas imobilizadas separadamente, indicando que o efeito da proximidade contribuiu para o aumento da atividade (HONDA; TANAKA; YOSHINO, 2015). No que diz respeito à aplicação de nanopartículas magnéticas como suporte para imobilização, Yang e colaboradores (2017), mostraram que a eficiência catalítica da peroxidase e glicose oxidase co-imobilizadas em nanopartículas magnéticas (imobilização direcionada por ligação com DNA) foi duas vezes maior, em comparação à mistura das enzimas livres (YANG et al., 2017).

Em uma proposta semelhante a deste trabalho, dois tipos de celulases já foram coimobilizadas em nanopartículas paramagnéticas, uma celobiohidrolase e uma $\beta$-glucosidase. As nanopartículas em questão demonstraram $100 \%$ de eficiência na imobilização para as duas enzimas e grande capacidade de reuso, pois as enzimas mantiveram ainda cerca de $80 \%$ da atividade após 3 ciclos, e de 40\% após 10 ciclos (SONG et al., 2016).

Até o momento, este é o primeiro estudo da co-localização de enzimas em nanopartículas magnéticas tendo como alvo o xiloglucano. Além disso, a maioria dos trabalhos que descrevem a co-imobilização de enzimas até hoje, reportam a utilização de duas ou no máximo três enzimas. 
Dentro do nosso conhecimento este também é o primeiro trabalho a propor a co-localização de quatro enzimas.

O objeto tema deste trabalho é, portanto, um sistema que se caracteriza como um nanomaterial híbrido, mimetizando a hierarquia enzimática que existe in vivo, por meio da coimobilização das enzimas ativas sobre o polissacarídeo xiloglucano. Portanto, a construção de um sistema híbrido enzimático nanoestruturado, neste caso, a co-imobilização de enzimas em nanopartículas paramagnéticas, é uma estratégia de engenharia de proteínas dentro da área de nanobiotecnologia que objetiva a despolimeralização do xiloglucano. 
OBJETIVOS 


\section{OBJETIVOS}

\subsection{Objetivos Gerais}

Estudar o efeito da co-imobilização de hidrolases em nanopartículas ferromagnéticas como estratégia de engenharia de proteínas para a despolimerização do xiloglucano.

\subsection{Objetivos Específicos}

- Expressão heteróloga da enzima endo- $\beta(1,4)$ glucano hidrolase de Aspergillus niveus - XegA

- Expressão heteróloga da enzima $\beta$-galactosidase de Trichoderma reesei - Bga1

- Expressão heteróloga da enzima $\alpha$-xilosidase de Escherichia coli-YicI

- Expressão heteróloga da enzima $\beta$-glucosidase de Hypocrea jecorina (Trichoderma reesei) Bgl1

- Preparação de nanopartículas ferromagnéticas

- Imobilização das enzimas em nanopartículas paramagneticas, individualmente e em conjunto

- Caracterização da atividade catalítica das enzimas imobilizadas individualmente

- Caracterização da atividade catalítica contra xiloglucano das nanopartículas paramagnéticas carregadas com as enzimas - biossistemas. 
CAPÍTULO I

EXPRESSÃO HETERÓLOGA DAS ENZIMAS COM CAUDA DE HISTIDINA PARA IMOBILIZAÇÃO POR AFINIDADE 


\section{Expressão heteróloga das enzimas com cauda de histidina para imobilização por afinidade}

\section{MATERIAIS E MÉTODOS}

\subsection{Expressão de XegA e YicI em Escherichia coli}

As sequências codificadoras e XegA e YicI já se encontravam previamente clonadas em vetores de expressão para E. coli, pET28a e pET22b, respectivamente. Da mesma forma, a expressão dessas enzimas em E. coli já havia sido otimizada em estudos anteriores. Assim, a expressão das enzimas em E. coli Rosetta (DE3) ocorreu da forma descrita a seguir. Alíquotas de DNA contendo aproximadamente $100 \mathrm{ng}$ das construções XegA-pET28A e YicI-pET22b foram usadas para transformar células eletrocompetentes de E. coli Rosetta (DE3) (procedimento descrito no item 1.6). Após a transformação e o surgimento de colônias em placas contendo o meio sólido LB ágar e antibióticos kanamicina $(50 \mu \mathrm{g} / \mathrm{mL})$ e cloranfenicol $(37 \mu \mathrm{g} / \mathrm{mL})$ para XegA-pET28a e ampicilina (100 $\mu \mathrm{g} / \mathrm{mL})$ e cloranfenicol $(37 \mu \mathrm{g} / \mathrm{mL})$ para YicI-pET22b, uma colônia fresca e isolada de cada placa foi inoculada em $10 \mathrm{~mL}$ de meio LB líquido contendo os antibióticos adequados para cada cultura. Estes pré-inóculos foram mantidos a $37^{\circ} \mathrm{C}$, por 16 horas sob agitação horizontal de $180 \mathrm{rpm}$. Uma alíquota de 1 a $2 \mathrm{~mL}$ de cada pré-inóculo foi inoculada em $150 \mathrm{~mL}$ de meio HDM (Heavy Density Medium: triptona 1,5 g, extrato de levedura 2,5 g, $100 \mathrm{~mL}$ de água deionizada, $\mathrm{pH}$ 7,5) contendo os mesmos antibióticos. Essas culturas foram mantidas a $37^{\circ} \mathrm{C}$ até atingirem uma densidade óptica $\left(\mathrm{DO}_{600 \mathrm{~nm}}\right)$ entre 0,5 e 0,8 para a enzima XegA e 0,7 para a enzima YicI. Após atingir a $\mathrm{DO}_{600 \mathrm{~nm}}$ adequada, os inóculos foram induzidos com a adição de IPTG. Para a indução de XegA foi adicionado IPTG na concentração de $0,5 \mathrm{mM}$ e para a indução da enzima YicI, foi adicionado IPTG 0,15 mM. A partir daí, a expressão de XegA foi conduzida por 4 horas a $30{ }^{\circ} \mathrm{C}$ sob agitação horizontal de $150 \mathrm{rpm}$ e a expressão de YicI foi realizada durante 16 horas, a $18{ }^{\circ} \mathrm{C}$ sob agitação horizontal de $150 \mathrm{rpm}$. As culturas resultantes foram então coletadas para posterior purificação.

\subsection{Purificação de XegA e YicI por cromatografia de afinidade}

XegA e YicI foram clonadas em vetores de expressão pET28a e pET22b, portanto ao foram expressas com uma cauda de histidinas (His-Tag) na região N-terminal. Assim, a purificação dessas enzimas foi realizada via cromatografia de afinidade, utilizando-se uma resina de níquel (HisPur 
Ni-NTA Resin, Thermo Fisher Scientific). As culturas de expressão das enzimas foram centrifugadas a $5000 \mathrm{rpm}$ por 10 minutos. O sobrenadante foi descartado e os precipitados de células foram ressuspendidos em tampão fosfato-salino (Fosfato de sódio $100 \mathrm{mM}$, Cloreto de sódio $250 \mathrm{mM}, \mathrm{pH} 8,0)$ contendo o detergente Triton-X a 1\%. Essa mistura foi golcada em gelo e submetida a pulsos de ultrassom ( $Q$ sonica), por 6 minutos sob pulsos de 10 segundos e intervalos de 10 segundos. O produto da lise por sonicação foi centrifugado a $5000 \mathrm{rpm}$ por 15 minutos e o sobrenadante, contendo as proteínas expressas na forma solúvel, foi adicionado a $1 \mathrm{~mL}$ de resina (HisPur Ni-NTA Resin, Thermo Fisher Scientific). A mistura foi mantida a temperatura inferior a $10{ }^{\circ} \mathrm{C}$ sob agitação por no mínimo 1 hora. Em seguida a mistura foi transferida para uma coluna vazia com placa porosa no fundo e então procedeu-se com a purificação, baseada em lavagens da resina com tampão fosfato-salino contendo crescentes concentrações de imidazol $(0,20 \mathrm{mM} .40$ $\mathrm{mM}$ e $250 \mathrm{mM}$ ). Todas as frações de lavagem e eluição foram coletadas e guardadas para posterior análise por SDS-PAGE. A fração com maior quantidade de proteína pura foi escolhida para ser concentrada utilizando tubos concentradores Vivaspin (GE Healthcare). Após a concentração, XegA foi ressuspendida e mantida em água deionizada e YicI em tampão fosfato-salino (fosfato de sódio $50 \mathrm{mM}, \mathrm{NaCl} 150 \mathrm{mM}$ ) em pH 8,0.

\subsection{Expressão de Bga1 em Pichia pastoris}

\subsubsection{Transformação de P. pastoris por eletroporação}

A sequência de Bgal já se encontrava clonada no vetor pPICZ $\alpha$ A (Thermo Fisher Scientific) para expressão em P. pastoris, de estudos anteriores. Para reunir quantidade de DNA plasmidial suficiente para transformação em $P$. pastoris, o vetor pPICZ $\alpha$ A contendo a sequência codificadora de Bgal foi multiplicado em células de E. coli DH10ß e purificado com uso do kit (PureYeld Plasmid Miniprep - Promega), de acordo com as instruções do fabricante. Para a transformação, 4 $\mu \mathrm{g}$ ou mais do constructo pPICZ $\alpha$ A-Bga1 foram diferidos com a enzima SacI em uma reação de 3 horas a $37^{\circ} \mathrm{C}$, com o objetivo de tornar o DNA linear para posterior eletroporação das células de levedura. O DNA após a digestão foi purificado com auxílio do kit Wizard $^{\circledR} S V$ Gel and PCR CleanUp System (Promega).

Para a eletroporação, células de P. pastoris GS115 foram estriadas em placas contendo meio YPD sólido, que foram mantidas em estufa a $30^{\circ} \mathrm{C}$ por, em média 3 dias, até o aparecimento de colônias brancas. Um colônia fresca e isolada foi lançada em pré-inóculo mantido por $16 \mathrm{~h}$ a $30^{\circ} \mathrm{C}$ 
sob agitação de $180 \mathrm{rpm}$ e em seguida uma alíquota desse pré-inóculo foi lançada em $100 \mathrm{~mL}$ de meio YPD líquido, mantido a $30^{\circ} \mathrm{C}$ sob agitação até atingir-se a D.O.600nm 2,0. A partir a cultura de células foi transferida para tubos falcon estéreis mantidos no gelo e centrifugada a 5000 rpm por 5 minutos. Em seguida, o sobrenadante foi descartado e as células precipitadas foram lavadas com água estéril gelada e com sorbitol $1 \mathrm{M}$ gelada, seguindo o protocolo de preparo de células de $P$. pastoris competentes descrito no manual do fornecedor das células e do vetor pPICZ $\alpha \mathrm{A}$ (EasySelect Pichia Expression Kit-Invitrogen).

As células de $P$. pastoris eletrocompetentes foram então submetidas a eletroporação na presença do DNA linearizado pPICZ $\alpha$ A-Bga1, em cubetas de eletroporação de $0,2 \mathrm{~cm}$, no aparelho Micropulser (Bio-Rad), na função específica para P. pastoris, de acordo com o protocolo de eletroporação descrito no manual Invitrogen. Após a eletroporaçào, as células foram ressuspendidas e mantidas em período de recuperação em $300 \mu \mathrm{L}$ de sorbitol $1 \mathrm{M}$ a $30^{\circ} \mathrm{C}$, sem agitação, por um período de 1 a 2 horas e em seguida foram espalhadas em placas contendo o meio sólido YPDS e o antibiótico zeocina a $100 \mu \mathrm{g} / \mathrm{mL}$. As placas foram mantidas em estufa a $30^{\circ} \mathrm{C}$ por 1 a 3 dias.

\subsection{Subclonagem de Bga1 e Bgl1}

\subsubsection{Desenho de oligonucleotideos iniciadores para subclonagem de Bgal e Bgll via CPEC}

Na perspectiva de superar os problemas de transformação de células de P. pastoris com o vetor pPICZ $\alpha$ A-Bga1, foi idealizada então a subclonagem de Bgal e Bgll em um outro vetor o qual vem sendo aplicado com sucesso em outros estudos do laboratório, vetor pPIC9kf1CT. Dessa forma, foram desenhados oligonucleotídeos iniciadores com o objetivo de realizar a subclonagem por reações de CPEC (Circular Polymerase Extension Cloning) (QUAN; TIAN, 2011), que consistem primeiramente de um fragmento constituído da sequência codificadora do gene a ser clonado com regiões flanqueadoras que correspondem ao vetor a ser empregado e posteriormente este fragmento funcionará como um megaprimer numa reação semelhante à uma PCR em que o fragmento com as regiões flanqueadoras se hibridiza com o vetor que irá receber o inserto, e o constructo completo (vetor + inserto) é amplificado pela ação de uma DNA polimerase de alta fidelidade. Para isso os oligonucleotídeos foram desenhados de forma a conterem de 15 a 18 nucleotídeos correspondentes à sequência do inserto e 25 nucleotídeos correspondentes à sequência do vetor, na região de clonagem entres os sítios de restrição para SnabI e AvrII, e que a temperatura 
de anelamento (TM) na região que se sobrepõe com a sequência do vetor alta, entre $60^{\circ} \mathrm{C}$ e $70^{\circ} \mathrm{C}$ para favorecer o pareamento das regiões. Na Figura 7, representação da região de clonagem do vetor $\mathrm{pPIC9kf1CT}$.

\subsubsection{Mutagênese sittio-dirigida em Bgll}

Uma vez escolhido o vetor pPIC9kf1CT como vetor de expressão para as enzimas Bga1 e Bgl1 em P. pastoris, foi verificado se existiam na sequência codificadora dessas enzimas, sítios de restrição para a enzima StuI, a qual é empregada na linearização do vetor para a etapa de transformação das células de P. pastoris com o DNA do constructo. Foi visto que na sequência de Bgl1 havia um sítio para StuI e para que esse sítio fosse eliminado, foram construídos oligonucleotídeos iniciadores correspondentes à região que incluía o sítio incorporando a troca de um nucleotídeo na sequência, com o objetivo de realizar uma mutagênese sítio dirigida silenciosa, ou seja sem alterar nenhum aminoácido, a partir de uma modificação na reação em cadeia da polimerase (PCR). Na PCR para mutagênese sítio-dirigida, a inserção da mutação na região alvo ocorre na primeira fase da reação a partir do anelamento dos oligonucleotídeos mutagênicos e a síntese de um fragmento mutante. Nas etapas seguintes ocorrem a extensão e amplificação do fragmento mutado. Assim, a reação de PCR mutagênica foi realizada com a enzima de alta fidelidade Phusion (New England Biolabs) e os oligonugleotídeos contendo a mudança na sequência. Ao final da reação, o produto da PCR foi digerido com a enzima DpnI (New England Biolabs), uma endonuclease específica para DNAs metilados. Dessa forma apenas o DNA mutante amplificado, o qual não foi metilado, continuou intacto e em seguida foi purificado. A partir daí o DNA purificado e tratado foi aplicado para transformar células de E. coli DH10 quimiocompetentes. Após incubação das placas inoculadas com as bactérias transformadas, algumas colônias isoladas foram coletadas de forma aleatória submetidas a reações de PCR de colônia para confirmação da transformação com o inserto Bgl1. Após a reação de PCR de colônia, os fragmentos obtidos foram aplicados em gel de agarose $1 \%$ corados com o corante SYBR Safe (Invitrogen) e comparados com o marcador de peso molecular de DNA de $1 \mathrm{~kb}$ (Thermo Fisher Scientific). As colônias identificadas como positivas foram inoculadas em $5 \mathrm{~mL}$ de meio LB contendo os antibióticos adequados e estas culturas foram incubadas a $37^{\circ} \mathrm{C}$, sob agitaçãoo de 180 rpm por 16 horas. Cada umas dessas culturas foi submetida à extração de DNA plasmidial (PureYeld Plasmid Miniprep - Promega) e esse DNA obtido foi analisado por sequenciamento. 


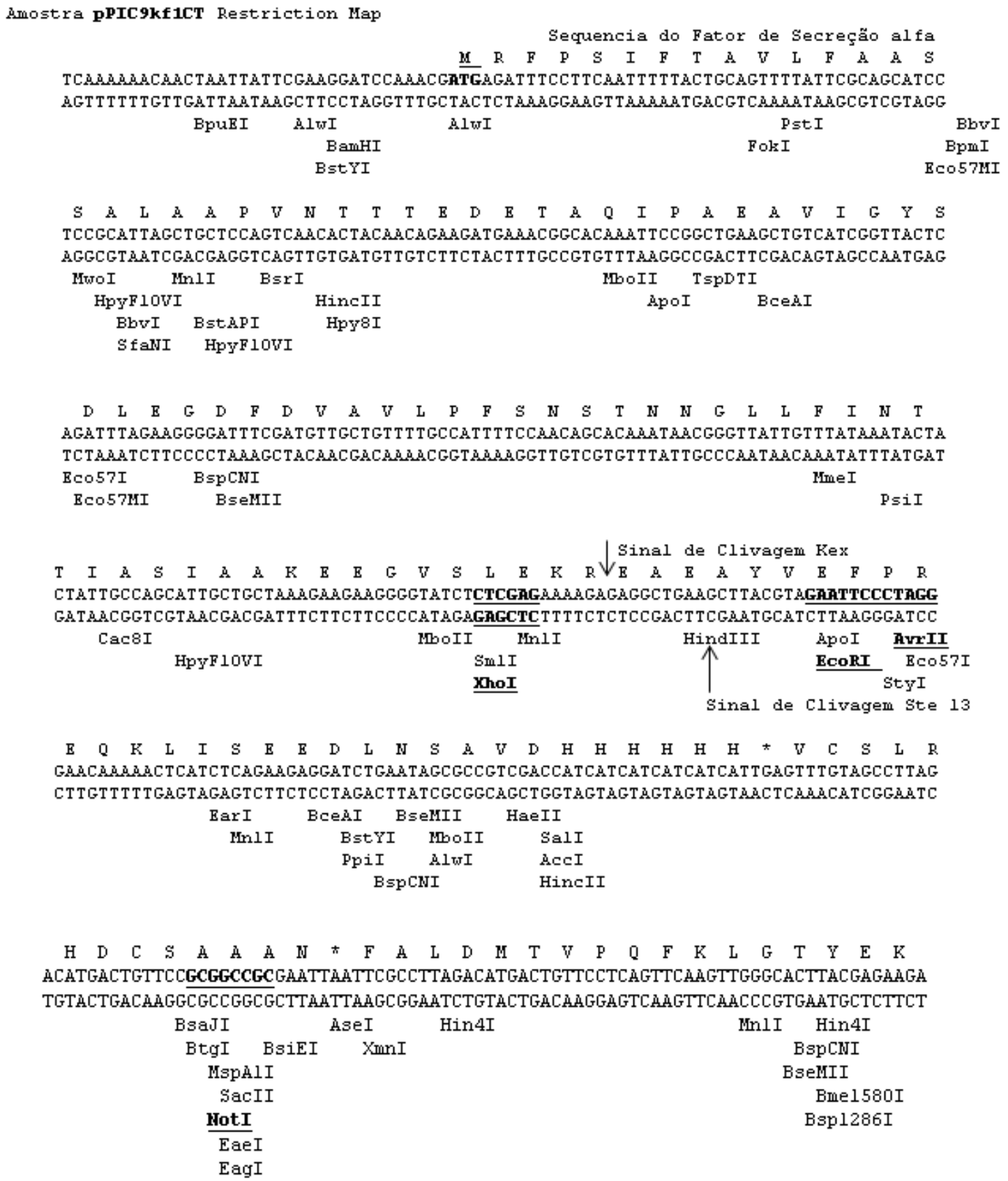

Figura 7. Sequência da região com os múltiplos sítios de clonagem do vetor pPIC9kf1CT.

\subsubsection{Subclonagem de Bgal e Bgll via CEPEC}

A reação de CPEC ocorre de forma semelhante a uma PCR. Na primeira etapa um inserto e um vetor linearizados são primeiramente desnaturados pela elevação da temperatura $98{ }^{\circ} \mathrm{C}$, em seguida as moléculas de fita-simples resultantes se anelam (temperatura de $70^{\circ} \mathrm{C}$ a $55^{\circ} \mathrm{C}$ ) pelas suas 
regiões complementares e se estendem usando umas as outras como molde para formarem moléculas fita-dupla de plasmídeos circulares.

Primeiramente, para obtenção do fragmento referente à sequência codificadora de cada enzima mais as regiões flanqueadoras complementares ao vetor, foram realizadas reações de PCR com a enzima DNA polimerase de alta fidelidade Phusion, usando como DNA molde as sequências das enzimas contidas nos vetores em que já se encontravam clonadas, Bgal-pPICZaA e Bgl1-pCCI, e os oligonucletídeos iniciadores desenhados para este fim, que continham 25 pares de bases correspondentes à sequência do vetor na região de clonagem. Os produtos da PCR foram aplicados em gel de agarose 1\% e após corrida e confirmação do tamanho do fragmento, estes foram cortados do gel e purificados com o kit de purificação de DNA Wizard ${ }^{\circledR} S V$ Gel and PCR Clean-Up System (Promega), de acordo com as instruções do fabricante.

Para ser empregado na reação de CPEC o vetor precisa estar aberto, ou seja na forma linear. Para isso, duas estratégias de linearização foram adotadas: digestão com as enzimas de restrição SnabI e AvrII (New England Biolabs) e reação de PCR com oligonucleotídeos que amplificam o vetor na forma linear. Uma vez purificados os fragmentos referentes a cada enzima, e o vetor linearizado, a reação do CPEC foi realizada utilizando-se 100 ng de vetor HF e enzima DNA polimerase Phusion (New England Biolabs) dentro das condições definidas pelo fabricante (reação descrita na Tabela 3). Foram testadas as seguintes proporções molares fragmento/vetor: 1:1, 2:1 e $6: 1$.

Tabela 3. Componentes da reação CPEC

\begin{tabular}{ll}
\hline Reagente & Quantidades \\
\hline Vetor linearizado & $100 \mathrm{ng}$ \\
Fragmento & Proporção molar à do vetor- 1:1 ou 2:1 ou 6:1 \\
Tampão Phusion HF $(5 \mathrm{x})$ & $5 \mu \mathrm{L}$ \\
dNTPs (2mM) & $5 \mu \mathrm{L}$ \\
DMSO & $0,75 \mu \mathrm{L}$ \\
Polimerase Phusion $2 \mathrm{U} / \mu \mathrm{L}$ & $0,5 \mu \mathrm{L}$ \\
$\mathrm{H}_{2} \mathrm{O}$ miliQ & q.s.p $25 \mu \mathrm{L}$ \\
\hline
\end{tabular}

No termociclador, os ciclos da reação CPEC foram programados da seguinte forma: desnaturação inicial a $98^{\circ} \mathrm{C}$ por $30 \mathrm{~s}$, em seguida de 25 a 30 ciclos de $30 \mathrm{~s}$ de desnaturação a $98^{\circ} \mathrm{C}$, $30 \mathrm{~s}$ de anelamento a $60^{\circ} \mathrm{C}$ e $15 \mathrm{~s} / \mathrm{kb}$ de extensão a $72^{\circ} \mathrm{C}$, seguidos de uma extensão final por $10 \mathrm{~min}$ a $72^{\circ} \mathrm{C}$. Após a reação, uma alíquota de cada um dos produtos da reações foi aplicado em gel de 
agarose $0,5 \%$, bem com uma alíquota de vetor vazio como controle para confirmação da amplificação dos constructos fragmento + vetor.

O restante dos produtos de reação CPEC foram utilizados para transformar células de E. coli DH10 $\beta$ ou XL1 Blue quimiocompetentes. Após as transformação as células foram inoculadas em placas contendo o meio de cultura LB ágar e os antibióticos apropriados e incubadas a $37^{\circ} \mathrm{C}$ por até 16 horas. Após esse tempo de incubação as colônias que surgiram nas placas foram coletadas para a realização de PCR de colônias para confirmação da clonagem dos insertos no vetor via CPEC.

\subsection{Subclonagem de Bga1 e Bgl1 por enzimas de restrição e ligação}

A estratégia de clonagem mais convencional, baseada em clivagem de inserto e vetor com enzimas de restrição e subsequente ligação com a enzima DNA ligase, também foi adotada na tentativa de subclonagem dos insertos de Bgal e Bgll no vetor pPIC9kf1CT. Para isso, os fragmentos dos insertos de Bgal e Bgll foram amplificados por reação de PCR usando os mesmos oligonucleotídeos iniciadores desenhados para as reações de CPEC. Os fragmentos amplificados com esses oligonucleotídeos possuem duas regiões flanqueadoras nas extremidades da sequência codificadora de cada enzima, que correspondem a parte da sequência do vetor pPIC9kf1CT que possui sítios para as enzimas de restrição Hind III e AvrII (New England Biolabs). Assim as duas enzimas foram usadas para digerir os insertos de Bagal e Bgl1 e o vetor pPIC9kf1CT em reações conduzidas a $37^{\circ} \mathrm{C}$ por 12 horas. Ao final da incubação, as reações foram inativadas a $65^{\circ} \mathrm{C}$ por 10 minutos.

Após a reação de digestão, os produtos foram purificados com kit de purificação de DNA (Promega) e em seguida o DNA purificado de cada reação foi quantificado em espectrofotômetro Nanodrop (Thermo Scientific). Em seguida o DNA de cada um dos insertos foi incubado juntamente com DNA do vetor digerido para ligação com a enzima T4 DNA ligase (Thermo Fisher Scientific). A quantidade de vetor usada em cada reação de ligação foi 10 ng e a quantidade de DNA de inserto foi calculada com base no tamanho em pares de bases do vetor e do inserto, nas proporções 3:1 e 5: de inserto para vetor. A ferramenta NEBiocalculator disponível na página da web (https://nebiocalculator.neb.com) foi utilizada para auxiliar no cálculo das quantidades de DNA a serem aplicadas. As reações de ligação foram conduzidas a $16{ }^{\circ} \mathrm{C}$ por 16 horas. Após inativação da reação a $65{ }^{\circ} \mathrm{C}, 5 \mu \mathrm{L}$ de cada produto de reação de ligação foi usado para transformar células eletrocompetentes de E. coli XL1 Blue. As células recém transformadas foram inoculadas em placas contendo o meio LB ágar e os antibióticos e incubadas a $37^{\circ} \mathrm{C}$ por 16 horas. Após esse tempo de incubação as colônias que surgiram nas placas foram coletadas para a realização de PCR 
de colônias para confirmação da clonagem dos insertos no vetor e os produtos das reações de PCR de colônias foram visualizados em géis de agarose $1 \%$.

\subsection{Transformação de células eletrocompetentes de $E$. coli}

Os produtos de reações de CPEC ou de ligação entre os genes Bgal e Bgll no vetor pPIC9kf1CT foram usados para transformar células de E. coli XL1 Blue por meio de eletroporação, para multiplicação dos vetores ou clones. Da mesma forma, as construções XegA-pET28A e YicIpET22b foram utilizadas para transformar células de E. coli Rosetta (DE3) para expressão. As células eletrocompetentes foram preparadas segundo o protocolo descrito por Sambrook \& Russel (2001). Desse modo, $50 \mu \mathrm{L}$ de células eletrocompetentes (eficiência $=2 \times 10^{6}$ colônias/ $\mu \mathrm{g}$ de DNA), que estavam acondicionadas a $-80{ }^{\circ} \mathrm{C}$ foram descongelados e imersos em banho de gelo por 10 minutos e, em seguida colocados em contato com 1 a $5 \mu \mathrm{L}$ dos produtos de reações CPEC, ou ligação entre gene e plasmídeo, ou vetor já contendo inserto. Como controle foram misturados 50 $\mu \mathrm{L}$ de células e $2 \mu \mathrm{L}$ de plasmídeo (aproximadamente $100 \mathrm{ng}$ ), que no caso do processo de subclonagem por ligação também tinha passado pelas mesmas condições de digestão enzimática e de ligação. As células eletrocompetentes acrescidas dos produtos de reação foram transferidas para cubeta de eletroporação gelada e estéril para serem submetidas a um pulso elétrico de $1,8 \mathrm{kV}$ por

$5 \mathrm{~ms}$ usando eletroporador (MicroPulser ${ }^{T M}-$ BioRad). Imediatamente após o pulso elétrico foi adicionado $1 \mathrm{~mL}$ de meio LB às células transformadas e as mesmas foram transferidas para um tubo estéril e mantidas sob agitação de $180 \mathrm{rpm}$ a $37^{\circ} \mathrm{C}$ por 45 minutos. Em seguida, 20 a $100 \mu \mathrm{L}$ dessa suspensão foram adicionados a uma placa de petri, contendo $10 \mathrm{~mL}$ de meio LB sólido e os antibióticos adequados, de acordo com a cepa de E. coli utilizada e o vetor transformado. As placas foram mantidas na estufa a $37{ }^{\circ} \mathrm{C}$ durante a noite. A verificação da presença do gene de interesse nas colônias foi realizada por PCR de colônia.

\subsection{SDS-PAGE}

As amostras de proteínas provenientes dos experimentos de expressão e purificação foram separadas em eletroforese em gel de poliacrilamida com SDS (SDS-PAGE), segundo Laemmli (1970) em condições redutoras usando-se um sistema de eletroforese BioRad MiniProtean 4. A concentração de poliacrilamida nos géis de separação foi de 10 a 12\% e no gel de concentraçãoo, de 5\%. Uma voltagem fixa de $200 \mathrm{~V}$ com amperagem livre foi aplicada nas corridas. Os marcadores moleculares utilizados foram o PageRuler Unstained Protein Ladder (Thermo Scientific) ou o 
Precision Plus Protein Kaleidoscope ${ }^{T M}$ Prestained Standard (BioRad). Os géis foram corados com Comassie Blue 0,1\% [em ácido acético 10\% (v/v) e metanol 50\% (v/v)]. 


\section{RESULTADOS}

\subsection{Expressão e Purificação XegA e YicI}

As enzimas XegA e YicI foram expressas em E. coli Rosetta (DE3), nas condições descritas em Materiais e Métodos e a purificação de ambas foi realizada por cromatografia de afinidade. A seguir as imagens de géis de SDS-PAGE com alíquotas de diferentes tempos de expressão das enzimas e de diferentes frações da purificação. Tanto na expressão de XegA, quanto na de YicI foi possível visualizar bandas únicas após a purificação, correspondentes aos seus pesos moleculares, $24 \mathrm{kDa}$ e $88 \mathrm{kDa}$ respectivamente.
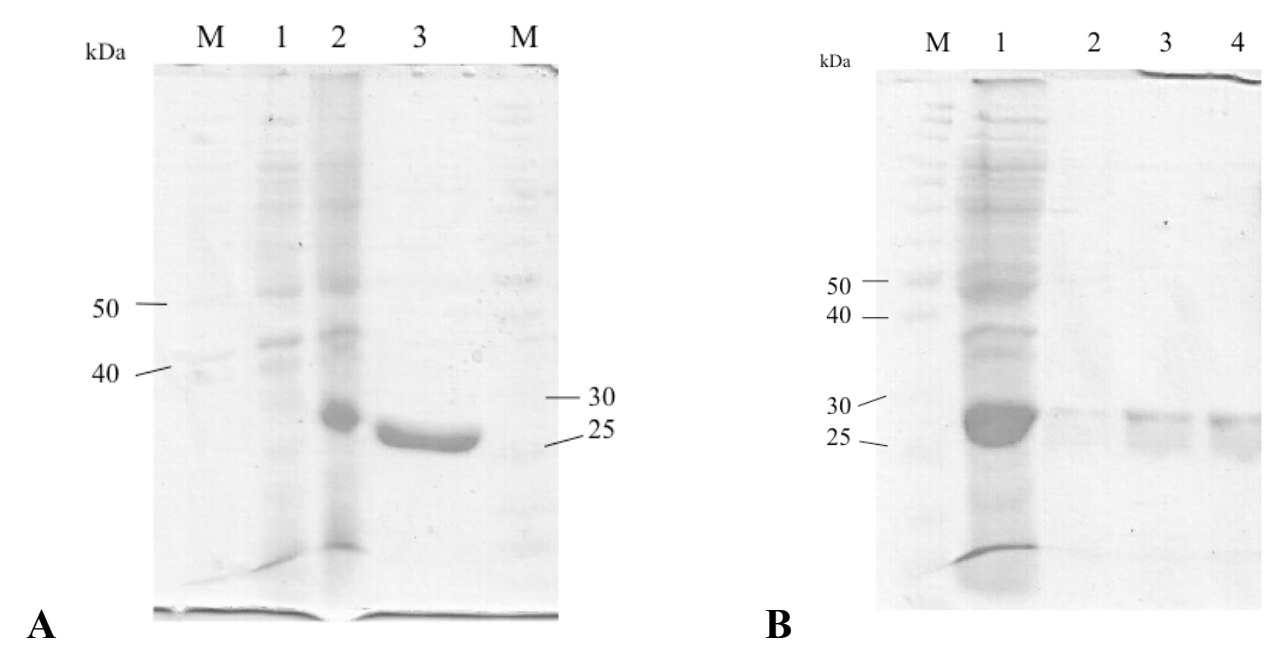

Figura 8. Gel de eletroforese de proteínas de expressão e purificação de XegA. A) Gel de poliacrilamida 12,5\% onde foram aplicadas alíquotas da cultura de células em diferentes tempos de expressão da proteína XegA: M- marcador de peso molecular; 1- cultura não induzida com IPTG; 2- 4 horas após indução; 3- proteína purificada, eluída com tampão fosfato-salino contendo imidazol 250mM; B) Gel de poliacrilamida 12,5\% onde foram aplicadas alíquotas das lavagens (frações) da purificação: M- marcador de peso molecular; 1- Fração de proteínas não ligadas à resina (flowthrough); 2Lavagem com tampão fosfato-salino; 3- Lavagem com tampão fosfato-salino contendo imidazol 20mM; 4- Lavagem com tampão fosfato-salino contendo imidazol 40mM; Fonte: a autora 


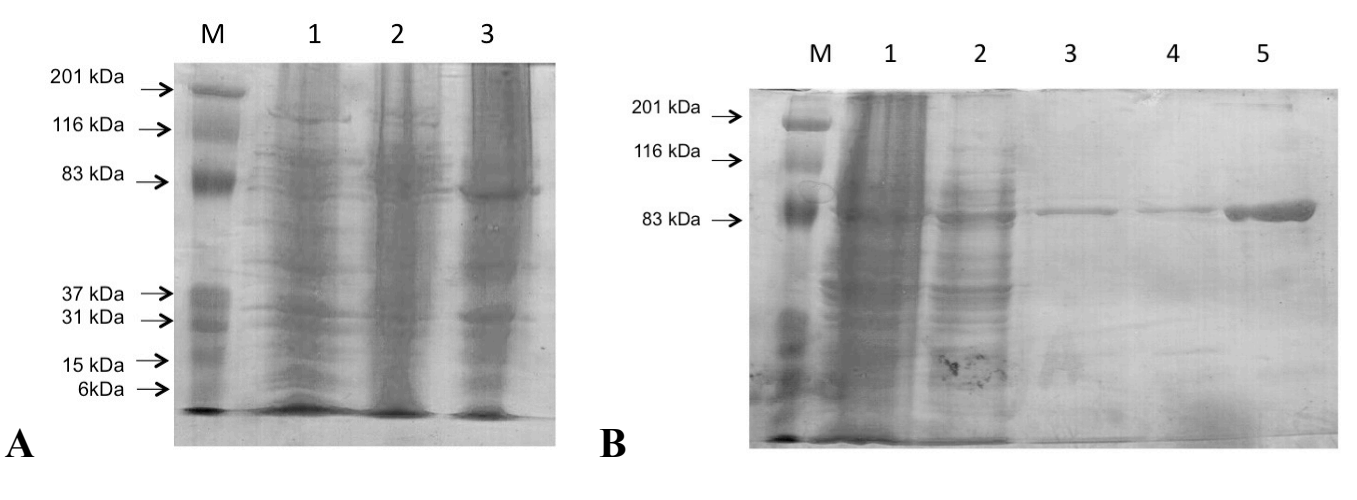

Figura 9. Gel de eletroforese de proteínas de expressão e purificação de YicI. A) Gel de poliacrilamida 12,5\% onde foram aplicadas alíquotas da cultura de células em diferentes tempos de expressão da proteína YicI: M- marcador de peso molecular; 1- cultura não induzida com IPTG; 2- 4 horas após indução; 3- 16 horas após indução. B) Gel de poliacrilamida 12,5\% onde foram aplicadas alíquotas das lavagens (frações) da purificação: M- marcador de peso molecular; 1- Fração de proteínas não ligadas à resina (flowthrough); 2- Lavagem com tampão fosfato-salino; 3Lavagem com tampão fosfato-salino contendo imidazol 20mM; 4- Lavagem com tampão fosfato-salino contendo imidazol 40mM; 5- Lavagem com tampão fosfato-salino contendo imidazol 250mM (eluição). Fonte: a autora

A fração da eluição com o tampão contendo $250 \mathrm{mM}$ de cada expressão foi selecionada para ser concentrada. Após a concentração XegA foi ressuspendida e mantida em água deionizada e YicI em foi ressuspendida em tampão fosfato-salino. Ambas as enzimas foram armazenadas a $4{ }^{\circ} \mathrm{C}$.

\subsection{Transformação de Pichia pastoris por eletroporação}

Dando continuidade à expressão de enzimas com cauda de histidina, a enzima Bgal se encontrava clonada no vetor pPICZ $\alpha$ A para expressão em P. pastoris. O constructo Bga1pPICZ $\alpha$ A foi preparado como descrito em Materiais e Métodos para a transformação de células de P. pastoris eletrocompetentes. No entanto, após várias tentativas, com diferentes quantidades de DNA linearizado e usando diferentes condições de transformação, não foi possível obter transformantes de P. pastoris com o constructo Bga1- pPICZ $\alpha$ A. Ainda, transformações controle com o vetor pPICZaA vazio linearizado também não obtiveram sucesso. Devido à essas dificuldades, optou-se pela mudança do plasmídeo para as expressões em P. pastoris, para outro vetor que estava sendo empregado com êxito nas clonagens de outros estudos do laboratório. Para isso foi escolhido o vetor pPIC9kflCT. 


\title{
2.3 Mutagênese sítio-dirigida de Bgl1
}

A mutagênese sítio-dirigida de Bgll foi realizada para que o sítio para a enzima de restrição StuI (AGGCT) fosse eliminado da sequência codificadora da enzima. A Figura 10 mostra parte da sequência de bgl1, com o sítio StuI em destaque.

\begin{abstract}
bgl1
GACAGTCACTCAACCTCCGGTGCCTCCGCCGAAGCAGTCGTCCCTCCAGCAGGAACTCCTTGGGGTACAGCCTATGATAAAGC AAAGGCTGCCTTGGCTAAGTTGAACCTTCAAGATAAAGTCGGTATTGTTTCTGGTGTCGGATGGAACGGTGGACCATGTGTTG GTAATACTTCCCCTGCTTCAAAGATTAGTTATCCATCTTTGTGCCTTCAGGATGGTCCTTTGGGAGTTAGATACTCCACCGGT TCAACTGCTTTTACACCAGGAGTTCAAGCAGCTTCTACTTGGGACGTCAATTTGATTAGAGAAAGAGGACAGTTCATCGGAGA AGAGGTTAAGGCCTCCGGTATTCATGTTATCCTTGGACCAGTCGCAGGTCCTTTGGGAAAAACTCCTCAAGGTGGAAGAAACT GGGAGGGTTTTGGAGTTGATCCATATTTGACAGGTATTGCTATGGGACAGACCATTAATGGTATCCAATCTGTCGGAGTTCAG GCCACCGCAAAGCATTACATCCTTAACGAACAAGAGTTGAACAGAGAAACTATCTCTTCCAACCCTGATGACAGAACCTTGCA CGAGCTTTATACTTGGCCATTCGCTGATGCCGTTCAGGCCAATGTTGCATCAGTCATGTGTAGTTACAACAAGGTTAACACTA CATGGGCTTGCGAAGATCAATACACCTTGCAGACTGTTCTTAAAGACCAATTGGGTTTTCCTGGATACGTTATGACTGACTGG AACGCCCAACACACCACTGTTCAGAGTGCAAATTCTGGTTTGGATATGTCTATGCCAGGTACTGACTTCAACGGAAACAATAG ACTTTGGGGTCCTGCTTTGACAAATGCCGTTAACTCAAATCAAGTCCCAACCAGTAGAGTTGATGACATGGTCACTAGAATTC
\end{abstract}

Figura 10. Parte da sequência do gene de Blg1. Em destaque a região do sítio reconhecido pela enzima de restrição StuI.

Assim, os oligonuclotídeos mutagênicos foram desenhados para corresponderem à essa região da sequência porém com a troca de um nucleotídeo que não levasse à troca de códon. Nesse caso, o códon AAG, que codifica para lisina, foi trocado para AAA, que também codifica o mesmo aminoácido. Dessa forma, os oligonucleotídeos mutagênicos desenhados foram: Bgl1-mut-foward (5’- GAG GTT AAA GCC TCC GGT ATT CAT GTT ATC CTT GGAC -3') e Bgl1-mut-reverse (5’ - GGA GGC TTT AAC CTC TTC TCC GAT GAA CTG TCC - 3’).

Após a reação de mutagênese sitio-dirigida, o produto da reação purificado e tratado com enzima DpnI foi aplicado para transformar células de E. coli DH10. Após o plaqueamento das bactérias transformadas, algumas colônias isoladas foram coletadas e submetidas a reações de PCR de colônia para confirmação da transformação com o inserto Bgl1 mutado. A Figura 11 apresenta o gel de eletroforese contendo os fragmentos obtidos. 


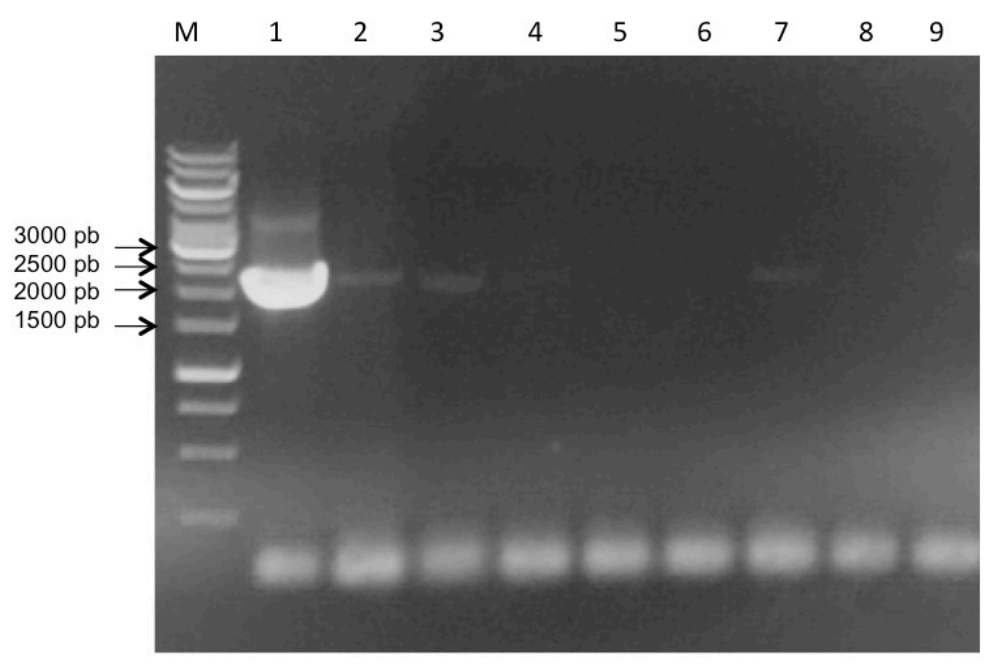

Figura 11. Gel de eletroforese de DNA dos produtos de PCR de colônias após mutagênese sítio-dirigida de Bgl1. Gel de agarose $1 \%$ com alíquotas dos produtos de PCR de colônias derivadas da transformação de células de E. coli com o DNA proveniente da mutagênese sítio-dirigida de Bgl1. M- marcador DNA ladder 1kb; 1 - controle positivo: alíquota do DNA molde submetido à reação de mutagênese sítio dirigida (Bgl1-PCCI); 2 a 9 - alíquotas de diferentes reações de

PCR de colônia, onde nas canaletas 2, 3 e 7 é possível notar bandas referentes ao tamanho do inserto indicando resultado positivo.

No gel de agarose foi possível identificar três bandas com o tamanho aproximado do inserto Bg11, indicando portanto que as três colônias estavam positivas para a transformação com o inserto mutante. As colônias identificadas como positivas foram multiplicadas e submetidas à extração de DNA plasmidial e o DNA obtido foi analisado por sequenciamento. Foi confirmado que os quatro clones identificados como positivos por PCR possuíam de fato a mutação induzida. Desses 4 clones, o que demonstrou melhor cobertura do sequenciamento foi escolhido para ser subclonado para o vetor pPIC9kf1CT.

\subsection{Subclonagem de Bga1 e Bgl1 via CPEC}

Os oligoncucleotídeos iniciadores desenhados para a amplificação do fragmento de cada inserto contendo regiões complementares ao vetor estão descritos na tabela a seguir. As regiões em azul se anelam com a região 5' (oligonucleotídeo forward) e 3' (oligonucleotídeo reverse) da sequência do gene e em preto a região que corresponde à sequência do vetor na região dos sítios de clonagem que deverá estar presente nos fragmentos amplificados. Sublinhados, os sítios ou parte dos sítios das enzimas de restrição SnaBI (TACGTA) e AvrII (CCTAGG). 
Tabela 4. Oligonucleotídeos desenhados para a reação CPEC

\begin{tabular}{ll}
\hline Oligonucleotídeo & Sequência \\
\hline Bga1_CPEC_forward & 5'CGAGAA AAGAGAGGCTGAAGTTACACTTCCATCGGATTG 3' \\
Bga1_CPEC_reverse & 5'CTGAGATGAGTTTTTGTTCCCTAGGGTAAGCTCCGTGTCTTTT 3' \\
Bgl1_CPEC_forward & 5' CGAGAAAAGAGAGGCTGAAGCTTACGACAGTCACTCAACC 3' \\
Bgl1_CPEC_reverse & 5' CTGAGATGAGTTTTTGTTCCCTAGGAGCGACACTAAGGGTTG 3' \\
\hline
\end{tabular}

Fonte: elaborado pela autora

Após a confirmação de mutagênese sítio-dirigida de Bgl1, os dois genes bga1 e bgll foram submetidos reação de PCR com os oligonucleotídeos iniciadores mencionados acima e a enzima DNA polimerase de alta fidelidade, usando-se como DNA molde os DNA plasmidiais Bga1pPICZ $\alpha A$ e Bgl1- pCCI. Na Figura 12, um gel de eletroforese com os produtos da reações de amplificação de cada fragmento. O gene de Bga1 possui cerca de 3000 pares de bases e o gene de Bgl1, aproximadamente 2500. Os genes foram amplificados com a adição de 25 pares de bases, diferença de tamanho que não é percebida em um gel de agarose 1\%. Após as amplificação dos fragmentos, estes foram purificados a partir da respectiva banda cortada do gel de agarose. Para linearização do vetor pPIC9kf1CT foram empregadas as enzimas de restrição SnabI e AvrII e também linearização por PCR usando oligonucleotídeos específicos para a linearização do vetor pPIC9kf1CT. A Figura 13 mostra o gel de eletroforese com o vetor linearizado.

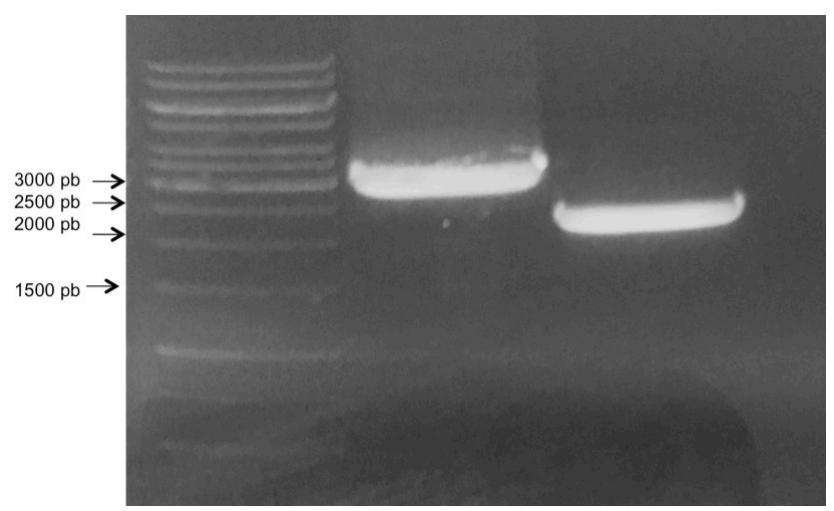

Figura 12. Gel de Eletroforese de DNA contendo fragmentos amplificados para a reação de CPEC. Gel de agarose 1\% contendo os fragmentos amplificados por PCR com os oligonucleotídeos desenhados para a finalidade do CPEC. Na primeira canaleta o fragmento Bga1, na segunda Bgl1. 


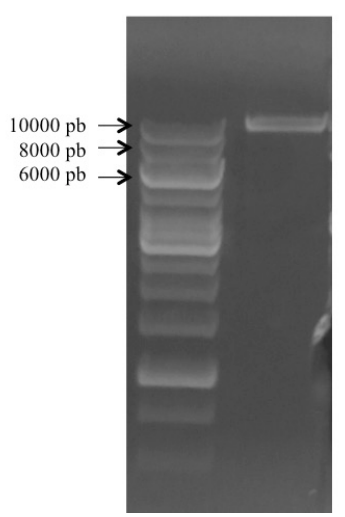

Figura 13. Gel de Eletroforese de DNA contendo o vetor linearizado. Gel de agarose 1\% contendo uma alíquota do vetor (cerca de 10000 pb) linearizado com a ação das enzimas de restrição. Ao lado foi aplicada uma alíquota maior que foi cortada do gel sem ser submetida à radiação UV.

A Figura 14 mostra o gel de eletroforese contendo os produtos da reação de CPEC, onde foi possível visualizar bandas com o tamanho aproximado do vetor vazio bem como bandas que aparecem mais acima que pouco migraram durante a corrida. Foram utilizados 5 a $10 \mu \mathrm{L}$ dos produtos das reações de CPEC para transformar células de E. coli DH10B quimiocompetentes. Algumas das colônias que cresceram nas placas após a transformação foram submetidas a PCR de colônias. A Figura 15 mostra o gel de eletroforese contendo produtos de reações de PCR de colônias. Não foi possível encontrar colônias positivas no gel apresentado nem em outras tentativas de clonagem com CPEC realizadas. Nos géis foi possível visualizar apenas bandas correspondentes à amplificação de uma banda de aproximadamente $250 \mathrm{pb}$, a qual é amplificada na PCR se o vetor se enconta vazio, portanto é o que caracteriza clones negativos. Clones positivos deveriam demonstrar uma banda com o tamanho aproximado do inserto mais os 250 pares de bases do vetor amplificados, ou seja, aproximadamente $3250 \mathrm{pb}$ para Bgal e $2750 \mathrm{pb}$ para Bgl1. Portanto, devido às dificuldades encontradas com a clonagem por $\mathrm{CPEC}$, foi decidido também realizar a clonagem com enzimas de restrição e DNA ligase.

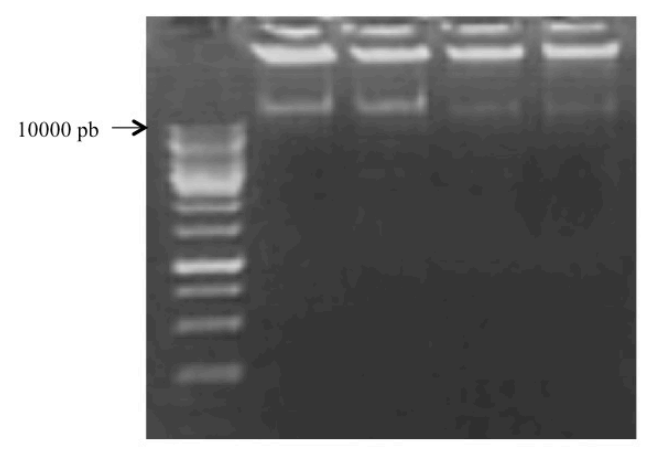

Figura 14. Gel de eletroforese de DNA contendo os produtos das reações de CPEC. Gel de agarose $1 \%$ contendo alíquotas de produtos do CPEC, visualizados acima da banda de 10kb do marcador molecular. 


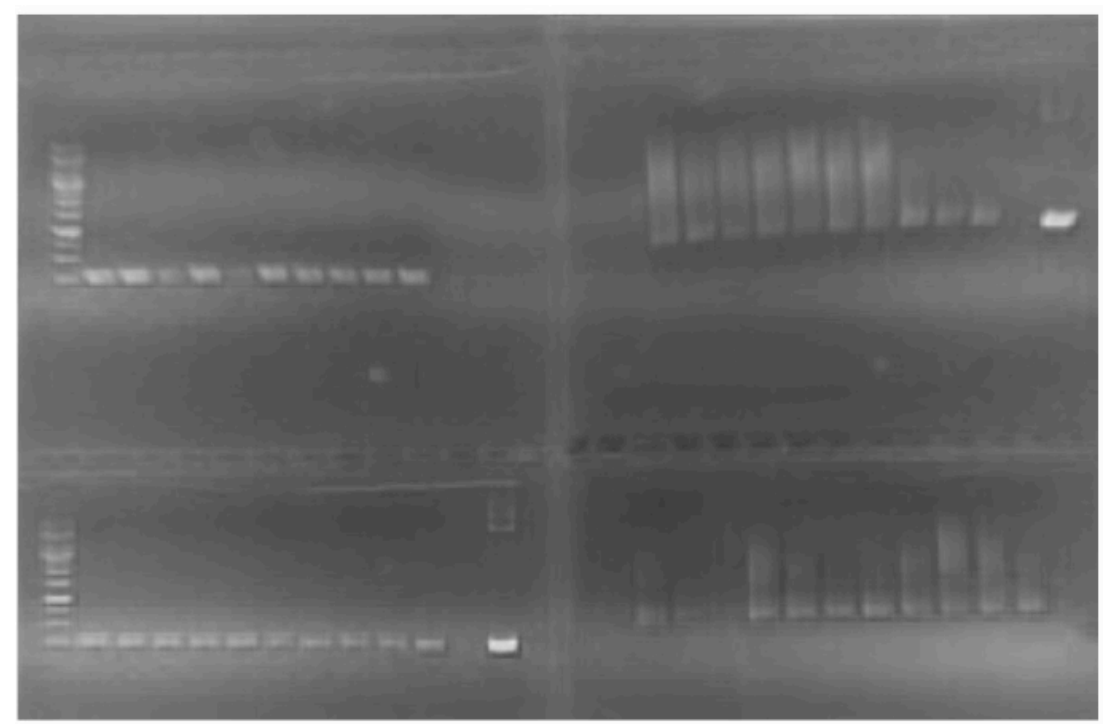

Figura 15. Géis de eletroforese de DNA contento produtos de PCR de colônias após transformação com os produtos de CPEC. Géis de agarose 1\% contendo os produtos de reações de PCR de colônias após a transformação de células de $E$. coli com os produtos das reações de CPEC.

\subsection{Subclonagem via enzimas de restrição e ligação}

$\mathrm{Na}$ estratégia de subclonagem dos genes Bgal e Bgl1 no vetor pPIC9kf1CT, o genes de Bga1 e Bgl1 foram amplificados da mesma forma que foram amplificados para a reação de CPEC e depois foram digeridos com as enzimas de restrição HindIII e AvrII. O vetor também foi digerido com ambas as enzimas. Após purificação dos DNAs digeridos, estes foram purificados e incubados nas proporções inserto:vetor de 3:1 e 5:1 com a enzima T4 DNA ligase. Após a ligação, $5 \mu \mathrm{L}$ do produto de cada reação foi usado para transformar células de E. coli XL1 Blue eletrocompetentes. Novamente, com a realização de PCRs de colônia não foi possível encontrar nenhum clone positivo, para nenhuma das enzimas (Figura 16).

A clonagem dos genes das enzimas Bgal e Bgll em vetor de expressão era uma etapa muito importante do projeto e se mostrou um gargalo visto às dificuldades enfrentadas em realizar a subclonagem dessas enzimas. Em paralelo, as enzimas Bgal e Bgll clonadas sem cauda de histina foram expressas para que ensaios preliminares de degradação do xiloglucano com as 4 enzimas imobilizadas por ligação covalente pudessem ser realizados. 


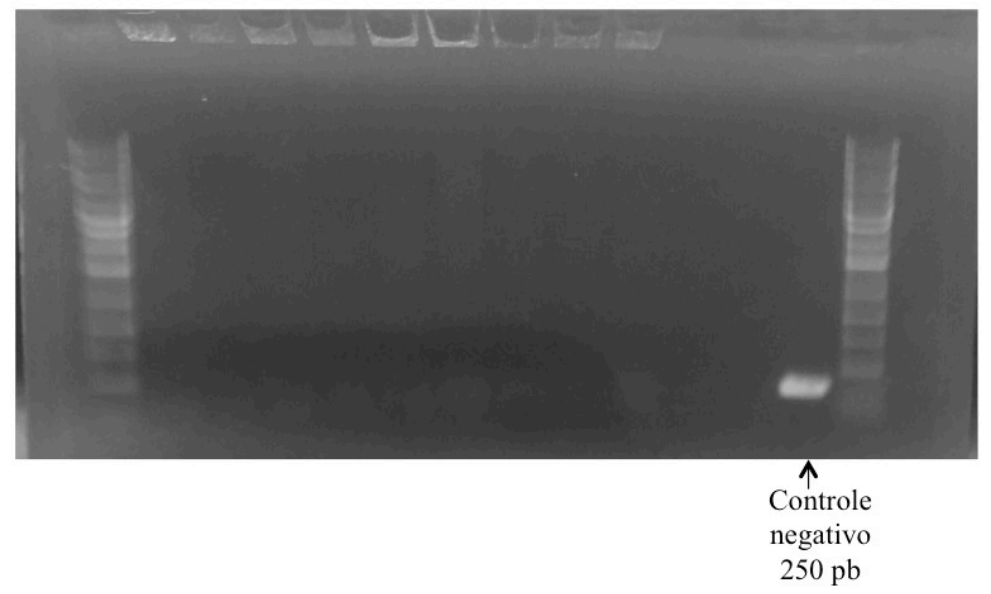

Figura 16. Géis de eletroforese de DNA contento produtos de PCR de colônias após transformação com os produtos de ligação. Gel de agarose $1 \%$ contendo os produtos das PCR de colônias após a transformação de células de $E$. coli com os produtos das reações de ligação. 
Capítulo II

\section{PREPARAÇÃO DO NANOMATERIAL BIOMIMÉTICO VIA IMOBILIZAÇÃO COVALENTE E CARACTERIZAÇÃO DAS ENZIMAS LIVRES E IMOBILIZADAS}




\section{Preparação do nanomaterial biomimético via imobilização covalente e caracterização das enzimas livres e imobilizadas}

\section{MATERIAIS E MÉTODOS}

\subsection{Expressão de Bga1 e Bgl1 em Pichia Pastoris}

As sequências de Bgal e Blg1 se encontravam inseridas em vetor pPICZaA e já transformadas em P. pastoris GS115, gentilmente cedidas pelo professor Dr. Marcos Silveira Buckeridge ao laboratório. Porém estes constructos não possuíam a cauda de histidina. Como não foi possível realizar a subclonagem dessas sequências em vetores que continham a cauda de histidina, optou-se por expressar estes constructos que já se encontravam inseridos em P. pastoris.

Primeiramente, uma pequena alíquota de células de $P$. pastoris contendo o cassete de expressão para cada enzima, Bgal e Bgl1, mantidas em estoque com glicerol $10 \%$ a $-80^{\circ} \mathrm{C}$, foi estriada em placas com o meio YPD sólido e antibiótico zeocina. As placas foram mantidas a $30^{\circ} \mathrm{C}$ por aproximadamente 48 horas e uma colônia isolada de cada placa foi inoculada em $25 \mathrm{~mL}$ de meio de cultura líquido BMGY (Buffered Complex Medium Containing Glycerol). Esses préinóculos foram mantidos a $30^{\circ} \mathrm{C}$, sob agitação de $200 \mathrm{rpm}$ por 18 horas. Após o período a $\mathrm{DO}_{600}$ das culturas foi verificada e em seguida as culturas foram centrifugadas a $3000 \mathrm{rpm}$ e os precipitados foram ressuspendidos no meio de cultura mínimo BMMY (Buffered Medium Containing Metanol) até que a D. $\mathrm{O}_{600}$ de todas as culturas se ajustasse a 1,0. As culturas ajustadas à nova D.O 600 foram induzidas com 500 de $\mu \mathrm{L}$ de metanol puro (concentração final de metanol $0,5 \%$ ). A adição de metanol foi repetida a cada 24 horas. A cada dia de expressão uma alíquota de cada cultivo foi coletada para monitoramento da D.O. e da atividade enzimática e em seguida armazenada a $-20^{\circ} \mathrm{C}$ para posterior análise por SDS-PAGE.

A expressão de Bgal e Bgl1 durou de 3 a 6 dias, de acordo com a detecção de atividade enzimática de cada enzima no cultivo, quando verificava-se o declínio da atividade enzimática a indução da expressão era encerrada. Em um dos cultivos, a expressão foi realizada por 6 dias para estudo do padrão de crescimento celular e da atividade enzimática.

\subsection{Purificação de Bga1 e Bgl1}

Após o término da expressão os cultivos de Bgal e Bgll em P. pastoris foram centrifugados a $5000 \mathrm{rpm}$ por 15 minutos em temperatura ambiente e os sobrenadantes separados para purificação. 
Esses sobrenadantes foram submetidos à diálise utilizando-se membrana (Sigma Aldrich) com um cut-off de $14 \mathrm{kDa}$. Em seguida os extratos dialisados foram concentrados utilizando-se tubos concentradores Vivaspin (GE Healthcare) e armazenados a $4^{\circ} \mathrm{C}$.

As alíquotas armazenadas da expressão foram concentradas de 10 a 20 vezes pelo método do ácido tricloroacético (TCA) e submetidas ao SDS-PAGE para análise da pureza das proteínas. Em alguns dos cultivos fez-se necessária uma etapa de cromatografia para a obtenção de Bgal e Bgl1 puras. Para isso os extratos dos cultivos de ambas as proteínas foram concentrados a $1 \mathrm{~mL}$ nos tubos concentradores e inseridos para purificação em uma coluna de cromatografia de exclusão molecular Superdex 200 (GE Healthcare) com tampão fosfato de potássio $50 \mathrm{mM}$, realizada em sistema para cromatografia líquida AKTA (GE Healthcare). A eluição das proteínas foi acompanhada monitorando-se a leitura de absorbâncias a $280 \mathrm{~nm}$ da fase móvel e todas as frações de eluição foram coletadas e guardadas para posterior análise em gel SDS-PAGE. O géis de poliacrilamida foram corados com o corante Coomassie Brilliant Blue para a vizualisação das bandas das proteínas e em alguns casos quando as proteínas estavam menos concentradas foi necessário corá-los com prata.

\subsection{Dosagem das atividades enzimáticas}

As dosagens das atividades das enzimas $\beta$-glucosidase, $\beta$-galactosidase e $\alpha$-xilosidase foram realizadas através da hidrólise dos substratos sintéticos $p$-nitrofenil- $\beta$-d-glicopiranosídeo (pNP$\beta \mathrm{Glu}$ ), $p$-nitrofenil- $\beta$-D-galactopiranosídeo (pNP- $\beta \mathrm{Gal}$ ) e $p$-nitrofenil $\alpha$-D- xilopiranosídeo (pNP$\alpha$ Xil), respectivamente, em tampão fosfato-citrato $100 \mathrm{mM}$ ou acetato de amônio $50 \mathrm{mM}, \mathrm{pH} 6,5$ a $40^{\circ} \mathrm{C}$ com volume final da reação igual a $60 \mu \mathrm{L}$. Ao final, a reação foi interrompida pela adição de $100 \mu \mathrm{L}$ de tetraborato de sódio saturado. O controle negativo foi constituído pela mesma mistura de reação, porém contendo água deionizada em vez de solução enzimática. $\mathrm{O} p$-nitrofenolato liberado foi, então, mensurado a $410 \mathrm{~nm}$ em espectrofotômetro em placas de ELISA.

As atividades enzimáticas específicas (Ae) foram expressas em nmol de $p$-nitrofenol.min ${ }^{1}$.nmol de enzima ${ }^{-1}$. O cálculo da quantidade de $p$-nitrofenol formado em cada reação foi baseado em uma função gerada pela construção da curva padrão da relação de absorbância a $410 \mathrm{~nm}$ e a quantidade de $p$-nitrofenol em reações com o volume final de $160 \mu \mathrm{L}$. Assim, uma unidade de atividade (U) é definida como a quantidade de enzima responsável pela liberação de 1 nmol de $p$ nitrofenolato (pNP) por minuto.

Para a determinação da atividade enzimática da endo-xiloglucanase XegA, foi usado como substrato o xiloglucano obtido de sementes de jatobá (Hymenaea courbaril, cuja extração foi 
implementada em experimentos no laboratório, baseando-se na metodologia descrita por Buckeridge et al. (1997). Assim, para a condução do ensaio enzimático, $50 \mu \mathrm{L}$ de xiloglucano $(0,5$ $\% \mathrm{~m} / \mathrm{v}$ ) em água deionizada e $50 \mu \mathrm{L}$ de solução enzimática diluída em tampão McIlvaine pH 6,0, foram incubados a $50^{\circ} \mathrm{C}$. Em seguida, a reação foi interrompida com $100 \mu \mathrm{L}$ do ácido 3,5dinitrosalicílico (DNS) e aquecida imediatamente a $100^{\circ} \mathrm{C}$ por 5 minutos. $\mathrm{O}$ branco foi constituído pela mesma mistura de reação, porém contendo água deionizada ao invés de solução enzimática. $\mathrm{O}$ composto alaranjado formado pela da oxidação do açúcar redutor foi mensurado pela absorbância a $540 \mathrm{~nm}$ em espectrofotômetro (MILLER, 1959). Da mesma forma que as reações com o substrato sintético pNP, a atividade específica para XegA foi expressa como nmol de açúcar redutor.min ${ }^{-}$ ${ }^{1}$.nmol de enzima ${ }^{-1}$. O cálculo da quantidade de açúcar liberado em cada reação foi baseado na função gerada pela construção da curva padrão da relação de absorbância a $450 \mathrm{~nm}$ e a quantidade de glicose em reações contendo DNS e com o volume final de $240 \mu \mathrm{L}$. Portanto, uma unidade de atividade $(U)$ foi definida como a quantidade de enzima responsável pela liberação de $1 \mathrm{nmol}$ de açúcar redutor por minuto.

Os resultados de atividade enzimática foram representados na forma de gráficos de atividade específica (U. nmol ${ }^{-1}$ ), elaborados com o uso do software GraphPad Prism versão 5.0 . Para cada gráfico foram inseridos os dados de cada replicata e plotados os valores das médias com barras de erro padrão da média (SEM).

\subsection{Preparação das nanopartículas ferromagnéticas}

A preparação das nanopartículas descritas a seguir foram patenteadas por Lara Aparecida Buffoni de Campos Carneiro e Richard John Ward na patente registrada sob o $\mathrm{n}^{\circ} \mathrm{BR}$ 102016021095-0.

Nanopartículas de magnetita $\left(\mathrm{Fe}_{3} \mathrm{O}_{4}\right)$ foram preparadas por co-precipitação de ions $\mathrm{Fe}^{2+}$ e $\mathrm{Fe}^{3+}$ em condições alcalinas, na presença de um surfactante não-iônico, Pluronic F127, que previne a agregação espontânea das partículas precipitadas. As partículas de $\mathrm{Fe}_{3} \mathrm{O}_{4}$ resultantes foram lavadas repetidamente com água destilada até $\mathrm{pH}$ neutro ser atingido, usando um ímã de neodímio. Foi determinado um teor de sólidos de $10 \%(\mathrm{~m} / \mathrm{m})$ para a suspensão de partículas final por secagem de uma alíquota. Posteriormente, adicionou-se quitosana $0,1 \%$ dissolvida em ácido acético $83 \mathrm{mM}$ à suspensão de partículas magnéticas e a mistura foi agitada durante 30 minutos à temperatura ambiente. Em sequência, as partículas magnéticas revestidas com quitosana foram tratadas com o agente de reticulação glutaraldeído. A reação ocorreu à temperatura ambiente e a suspensão de partículas foi subsequentemente mantida a $4^{\circ} \mathrm{C}$ durante $16 \mathrm{~h}$. Para remover o excesso de 
glutaraldeído, as partículas foram separadas com um ímã de neodímio e lavadas com água destilada. A partir desta etapa as partículas estavam prontas para as reações de imobilização por ligação covalente.

Em alguns casos, foi realizada a imobilização das enzimas por afinidade histidina- $\mathrm{Ni}^{2+}$. Para isso, as nanopartículas magnéticas tratadas com glutaraldeído foram incubadas durante a noite a 37 ${ }^{\circ} \mathrm{C}$ e $180 \mathrm{rpm}$ numa solução a $0,05 \%(\mathrm{~m} / \mathrm{v})$ de ácido $\mathrm{N}$ - (5-amino-1-carboxi-pentil) iminodiacético (AB-NTA) em 0,1 M HEPES pH 8,0, depois enxaguadas 3 vezes com água mili-Q. As partículas foram, então, incubadas em solução de bloqueio dos sítios inespecíficos (glicina a $1 \%(\mathrm{~m} / \mathrm{v}) \mathrm{pH}$ 9,8) durante $1 \mathrm{~h}$ a $37^{\circ} \mathrm{C}$ e $180 \mathrm{rpm}$ e lavadas 3 vezes com água mili-Q, 3 vezes com $\mathrm{NiCl}_{2} 0,5 \mathrm{M}$ e 3 vezes com água mili-Q para produzir partículas magnéticas funcionalizadas imobilizadas por NiNTA.

\subsection{Preparo do nanomaterial acoplado às enzimas}

Uma vez sintetizadas as nanopartículas ferromagnéticas funcionalizadas, as enzimas foram inicialmente acopladas individualmente ao nanomaterial, com o objetivo de caracterizá-los bioquimicamente. Para os ensaios de imobilização individual das enzimas já purificadas, foram utilizados $200 \mu \mathrm{L}$ de nanopartículas (teor de sólidos $3 \% \mathrm{~m} / \mathrm{v}$ ), os quais foram adicionados a $200 \mu \mathrm{L}$ de uma solução contendo de a enzima a ser imobilizada na concentração $1 \mathrm{mg} / \mathrm{mL}$ em tampão

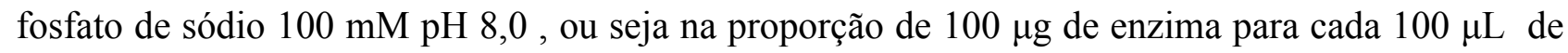
nanopartículas. As nanopartículas foram deixadas em contato com as enzimas a $4{ }^{\circ} \mathrm{C}$ por 16 horas e, então, o sobrenadante foi retirado seu volume mensurado e as partículas lavadas três vezes com 1 $\mathrm{mL}$ de tampão fosfato de sódio $50 \mathrm{mM} \mathrm{pH} \mathrm{8,0} \mathrm{para} \mathrm{remoção} \mathrm{das} \mathrm{proteínas} \mathrm{não} \mathrm{ligadas.} \mathrm{Ao} \mathrm{final} \mathrm{das}$ lavagens as nanoestruturas foram ressuspendidas em $200 \mu \mathrm{L}$ do mesmo tampão de lavagem e utilizadas para os ensaios catalíticos.

A quantidade de proteína imobilizada foi calculada indiretamente pela determinação da quantidade de proteína não ligada presente no sobrenadante da reação de ligação e nas lavagens. A determinação da quantidade de proteína não ligada foi feita principalmente pela mensuração da atividade específica da enzima livre antes da imobilização e após, no sobrenadantes e lavagens, determinando-se a quantidade de enzima ativa presente nas lavagens e portanto estimando-se a quantidade de enzima ativa remanescente nas nanopartículas. Em algus casos, a determinação da quantidade de enzima não ligada também foi feita pelo método de determinação de proteínas totais

descrito por Read e Northcote (1981), sendo este um método derivado do método de Bradford (1976), que utiliza o corante Coomassie brilliant blue BG-250. 


\subsection{Determinação do pH ótimo}

$\mathrm{O} \mathrm{pH}$ ótimo das enzimas livres e imobilizadas foi determinado avaliando-se a atividade desta enzima em diferentes pHs. As reações foram conduzidas a $40{ }^{\circ} \mathrm{C}$ e as misturas de reação foram préaquecidas por 5 minutos até que a enzima fosse adicionada. O tampão Mcllvaine foi utilizado para todos os pHs $(2,5$ a 8,0). Os experimentos foram conduzidos em triplicata. A mistura de reação (60 $\mu \mathrm{L}$ ) foi incubada a $40^{\circ} \mathrm{C}$ em variados tempos dependendo da enzima, e em seguida, $100 \mu \mathrm{L}$ de tetraborato de sódio saturado foram adicionados a fim de paralisar a reação, bem como para proporcionar um $\mathrm{pH}$ alcalino suficiente para que o produto da hidrólise dos substratos $p$ NPs, $p$ nitrofenolato, permanecesse desprotonado, garantindo a absorção deste composto a $410 \mathrm{~nm}$. No caso da enzima XegA, as reações foram realizadas pelo método do DNS, cujos produtos foram medidos a $540 \mathrm{~nm}$.

\subsection{Determinação da temperatura ótima}

Para a determinação das temperaturas ótimas das enzimas, foram incubadas na presença do tampão McIlvaine, pH 6,0 e do respectivo substrato pNP (2 mM), ou xiloglucano $(0,5 \% \mathrm{~m} / \mathrm{v})$ no caso da enzima XegA, a diferentes temperaturas, para que o efeito da mudança na temperatura fosse avaliado através da atividade específica correspondente. Os experimentos foram conduzidos em triplicata.

\subsection{Estudo de reuso das enzimas imobilizadas}

As enzimas imobilizadas individualmente foram avaliadas com relação ao efeito de repetidas utilizações. Para isso, após imobilização das enzimas às partículas paramagnéticas, foi medida a atividade catalítica de cada uma das enzimas, em sua respectiva temperatura ótima e $\mathrm{pH}$ ótimo, e assim se realizaram ciclos sucessivos de lavagem com tampão fosfato de sódio $50 \mathrm{mM}, \mathrm{pH} 8,0$ e medição da atividade. 


\section{RESULTADOS}

Uma vez que durante o período de execução deste trabalho não foi possível a subclonagem de Bgal e Bgl1 nos vetores que continham cauda de histidina, ambas as proteínas foram expressas sem a presença da tag de afinidade. Então considerou-se a imobilização de todas as enzimas via ligação covalente, o que é possível graças à presença do glutaraldeído na preparação das nanopartículas, promovendo o intercruzamento (cross-linking) entre partículas e as nanopartículas revestidas de quitosana.

Como descrito na patente depositada e nos estudo publicado por Carneiro e Ward (2018), as nanopartículas ferromagnéticas foram idealizadas para imobilização de proteínas pela afinidade da cauda de histidina presente na proteína com o $\mathrm{Ni}^{2+}$ presente nas partículas, ou seja uma interação não-covalente. Para a preparação das nanopartículas funcionalizadas, primeiramente ions $\mathrm{Fe}^{2+} \mathrm{e}$ $\mathrm{Fe}^{3+}$ em condições alcalinas e as partículas formadas são revestidas com quitosana. Em seguida as partículas magnéticas revestidas por quitosana são tratadas com glutaraldeído, devido sua ação como agente reticularizante. Para a imobilização via afinidade, pela coordenação do anel imidazólico das histidinas com o $\mathrm{Ni}^{2+}$, a preparação das nanopartículas prossegue com a adição de grupos amino pela incubação com AB-NTA e de grupos $\mathrm{Ni}^{2+}$ pela incubação com $\mathrm{NiCl}_{2}$ (CARNEIRO; WARD, 2018). No entanto, para a finalidade de imobilização via ligação covalente, as nanopartículas tratadas até a etapa de reticularização com o glutaraldeído são capazes de promover essas ligações.

O glutaraldeído é comumente usado como agente de ativação do suporte e de intercruzamento (cross-linking) na imobilização de enzimas em diversos tipos de suporte. Isso porque possui grupos funcionais reativos capazes de formar ligações inter ou intra cadeias poliméricas, como suportes sólidos aminados e proteínas, através dos grupo as amino de alguns resíduos de aminoácidos como a lisina (BETANCOR et al., 2006; GONSALVES et al., 2011). Neste caso, o suporte sólido são as nanopartículas magnéticas revestidas de quitosana. A imobilização por ligação covalente em quitosana ativada por glutaraldeído é um dos métodos mais empregados, por conta dos grupos amino existentes na estrutura da quitosana que reagem com este agente em condições brandas e próximas da neutralidade (MENDES et al., 2011). As ligações covalentes entre enzima e suporte ocorrem porque alguns grupos funcionais dos resíduos das proteínas, como aminas e hidroxilas, reagem com grupos do suporte que foram ativados pelo glutaraldeído (CARDOSO; DE MORAES; CASS, 2009).

Dessa forma optou-se pela aplicação das nanopartículas ferromagnéticas revestidas com quitosana e funcionalizadas com o glutaraldeído para a imobilização das quatro enzimas. É 
importante ressaltar que as enzimas XegA e YicI continuaram sendo expressas da mesma forma descrita no Capítulo I, portanto contendo cauda de histidinas. A presença da tag de afinidade, no entanto, não deve participar nem interferir na formação das ligações covalentes.

Também é importante pontuar que diferentemente da imobilização por afinidade, que acontece em apenas um ponto e é específica, a imobilização por ligação covalente tem característica inespecífica e multipontual, visto que vários grupos funcionais das proteínas podem estar envolvidos nas ligações com o suporte.

\subsection{Expressão e purificação das enzimas Bga1 e Bgl1}

A expressão das enzimas Bgal e Bgll (sem cauda de histidina) em Pichia pastoris foi monitorada a cada 24 horas pela D.O.600nm e pela atividade enzimática. Nas Figuras 17 e 18, o andamento da expressão em termos de D.O. e atividade, respectivamente ao longo de 5 dias de expressão, com indução pela adição de metanol a cada 24 horas.

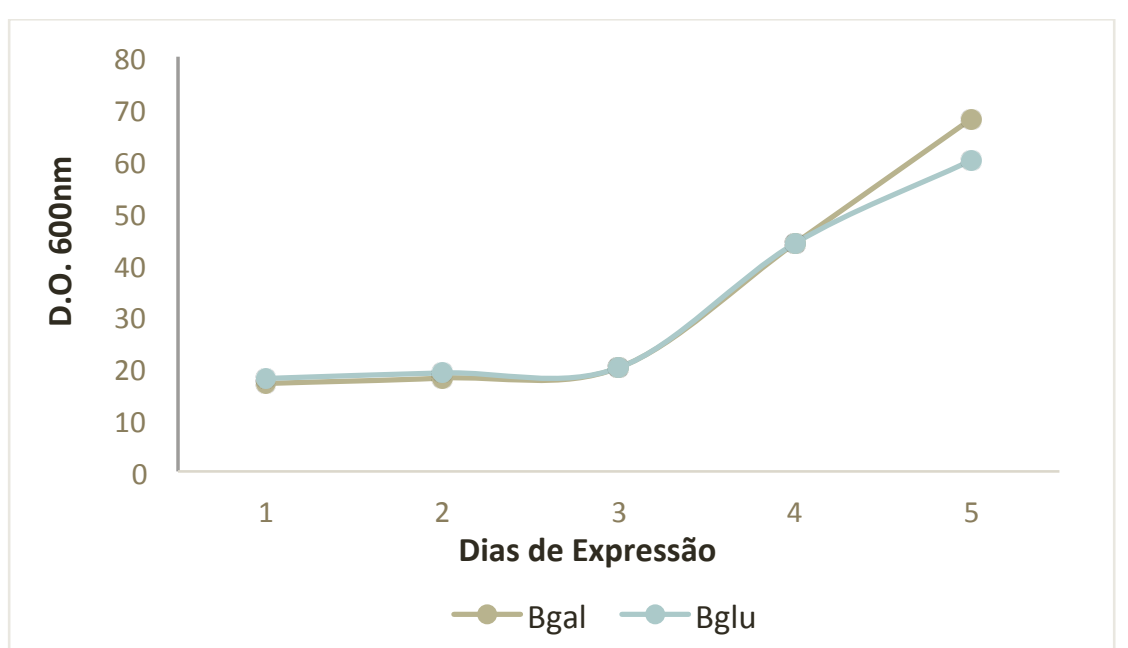

Figura 17. Crescimento dos cultivos de P. pastoris GS115 para expressão das enzimas Bgal e Bgl1 ao longo dos dias de indução. 


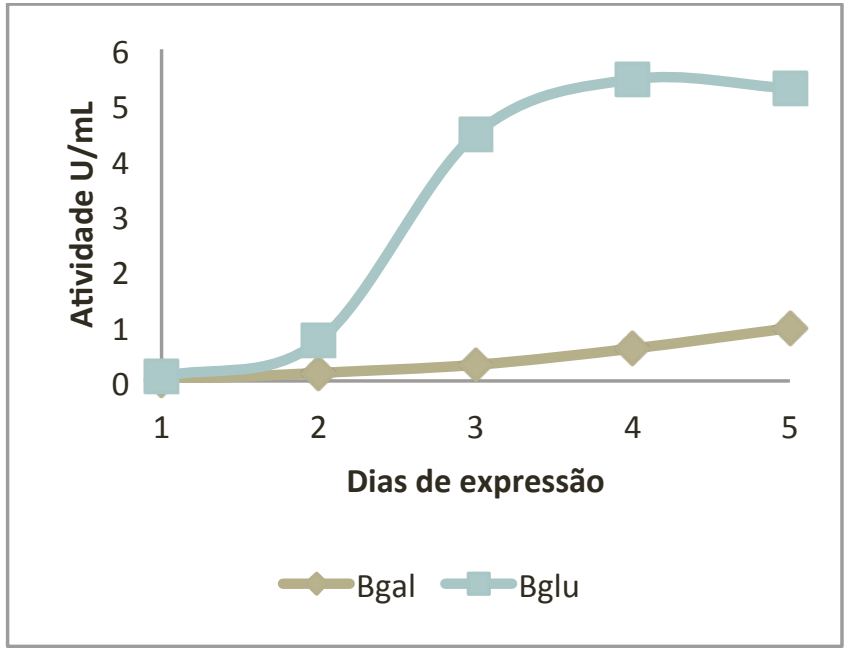

Figura 18. Atividade enzimática por mililitro dos cultivos de P. pastoris GS115 expressando Bga1 e Bgl1 ao longodos 5 dias de indução.

As alíquotas de cada dia de indução foram coletadas para eletroforese de proteínas SDSPAGE (Figuras 19 e 20), onde foi possível visualizar as bandas de aproximadamente 109 e 79 kDa de Bgal e Bgl1, respectivamente. No entanto várias outras bandas contaminantes também foram visualizadas nos géis, indicando a secreção de outras proteínas pela levedura $P$. pastoris.

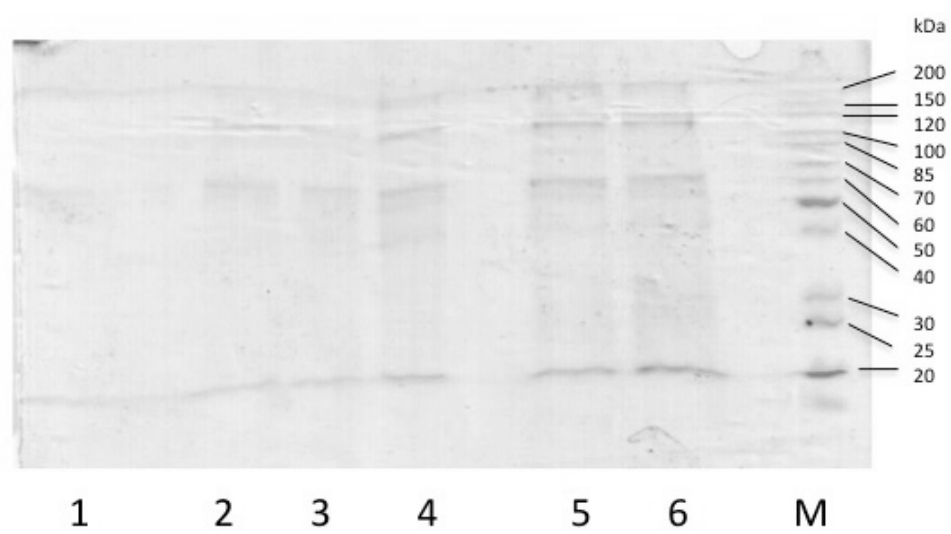

Figura 19. Gel de poliacrilamida $12,5 \%$ contendo as alíquotas dos dias de expressão de Bga1. 1 a 6 - Primeiro a sexto dia de expressão; M- marcador de peso molecular. 


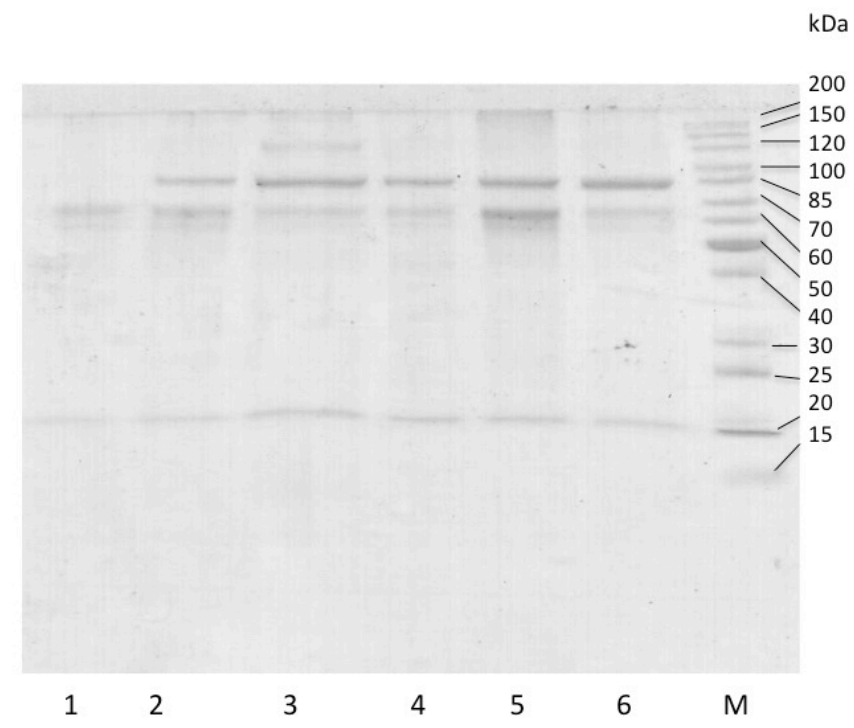

Figura 20. Gel de poliacrilamida 12,5\% contendo as alíquotas dos dias de expressão de Bgl1. 1 a 6 - Primeiro a sexto dia de expressão; M- marcador de peso molecular.

Após 6 dias de expressão, as culturas de P. pastoris foram coletadas e centrifugadas e como, como $P$. pastoris é um sistema de expressão que secreta as proteínas heterólogas graças a um fator de secreção, o sobrenadante de cada cultura foi separado para purificação. O extrato bruto contendo cada enzima foi concentrado antes da purificação, e $1 \mathrm{~mL}$ de cada um foi aplicado no sistema de cromatografia para purificação por exclusão molecular ou filtração em gel. As frações eluídas na purificação foram coletadas e posteriormente aplicadas em gel de SDS-PAGE (Figura 21).

A
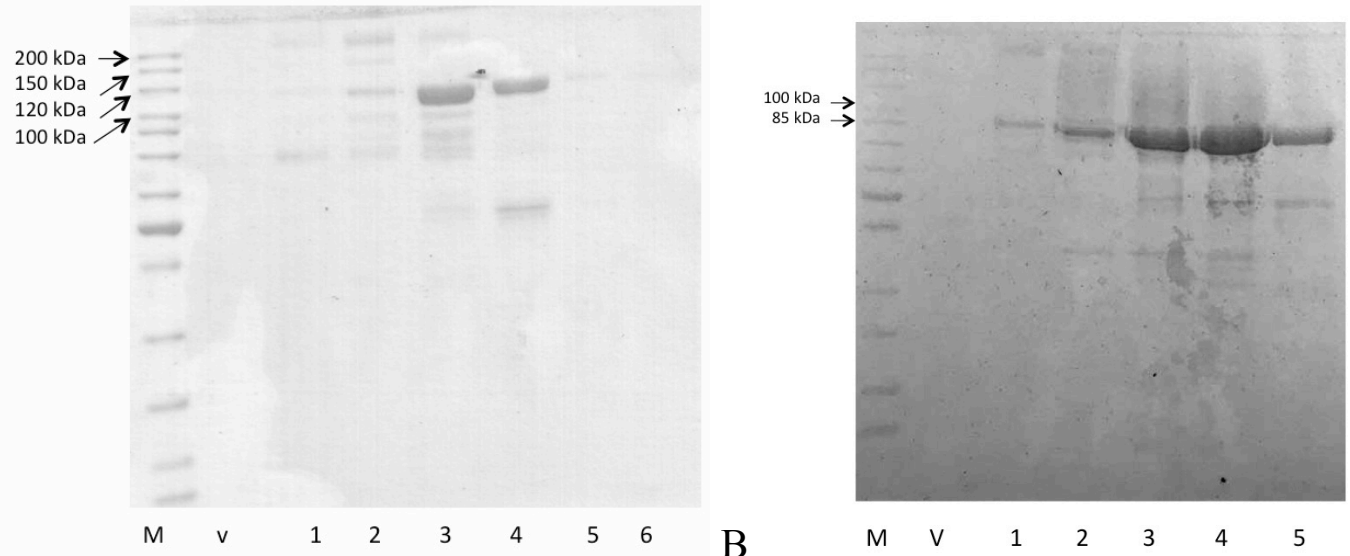

Figura 21 . Géis de poliacrilamida 12,5\% contendo as frações eluídas na cromatografia de exclusão molecular. A) Vvolume void; 1 a 6 alíquotas de purificação de Bga1; B) V- volume void; 1 a 6 alíquotas de purificação de Bgl1; Mmarcador de peso molecular. 
Foi possível visualizar nos géis que a enzima Bga1, de aproximadamente 109 kDa foi eluída nas frações 1 a 6 , estando presente em maior quantidade nas frações 3 e 4, mas não totalmente pura. Já a enzima Bgl1, de aproximadamente $78 \mathrm{kDa}$, foi eluída nas frações de 1 a 5, estando presente em maior quantidade nas frações 3 e 4, porém também não totalmente pura. Para dar continuidade aos estudos, foram selecionadas as frações com menor presença de proteínas contaminantes, 4 para Bga1 e 3 para a Bgl1, visando a aplicação destas na imobilização com as nanopartículas.

Após o estudo inicial das curvas de crescimento e atividade enzimática dos cultivos de Bgal e Bgl1, os cultivos seguintes foram realizados em 3 ou 4 dias, uma vez que notou-se o decaimento da atividade enzimática após o terceiro dia de indução. Para estes cultivos também não considerou-se necessário a etapa de cromatografia para purificação, visto que a presença de contaminantes no extrato foi considerada mínima e atividade específica de cada enzima foi considerada alta. Os sobrenadantes separados dos precipitados de células foram dialisados contra água deionizada, concentrados em tubos concentradores, tiveram a concentração de proteínas medida nos espectrofotômetro Nanodrop e em seguida já aplicados nos experimentos posteriores.

Nas figuras a seguir, os gráficos e $\mathrm{DO}_{600 \mathrm{~nm}}$ e atividade enzimática dos cultivos de 3 e 4 dias e na Figura 26 os géis de SDS-PAGE contendo alíquotas da expressão concentradas cerca de 20 vezes e das enzimas após diálise e concentração.

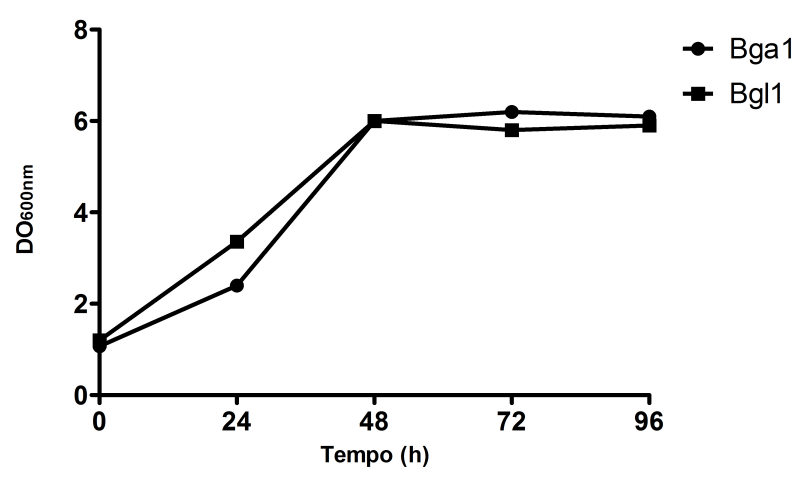

Figura 22. Densidade ótica das culturas de Bgal e Bgl1 ao longo de 96 horas (4 dias) de expressão. Fonte: elaborado pela autora 

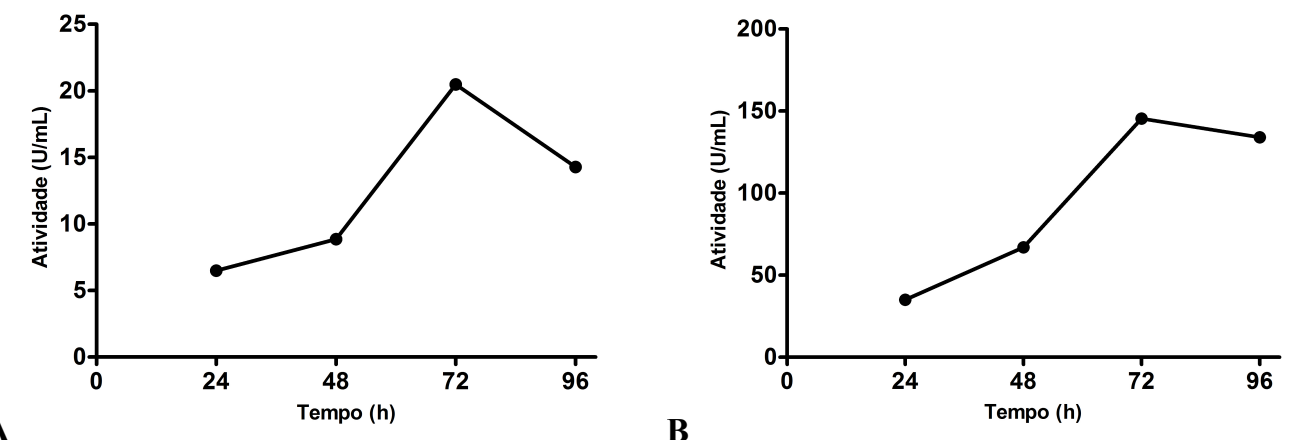

Figura 23. Atividade por mililitro dos cultivos de Bgal (A) e Bgll (B), ao longo de 96 horas (4 dias) de expressão. Fonte: elaborado pela autora

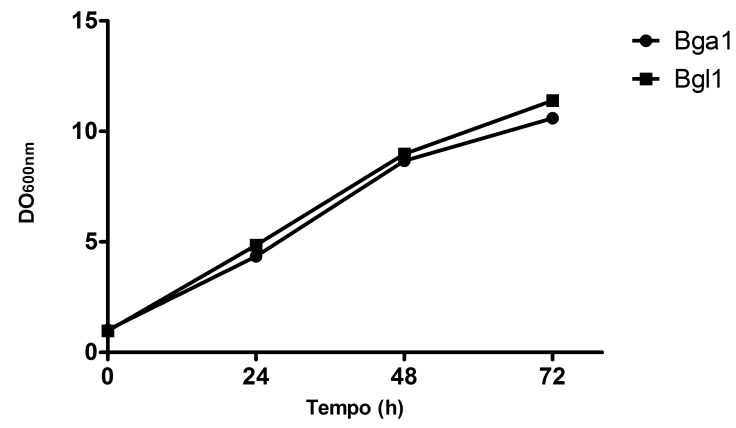

Figura 24. Densidade ótica das culturas de Bga1 e Bgl1 ao longo de 72 horas (3 dias) de expressão. Fonte: elaborado pela autora
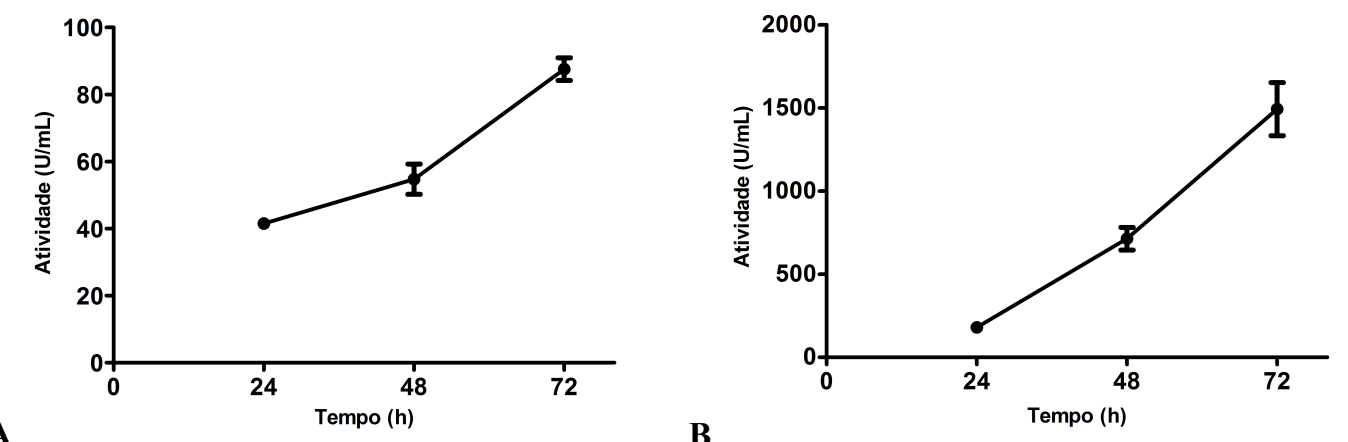

Figura 25. Atividade por mililitro dos cultivos de Bgal (A) e Bgl1 (B), ao longo de 72 horas (3 dias) de expressão. Fonte: elaborado pela autora 


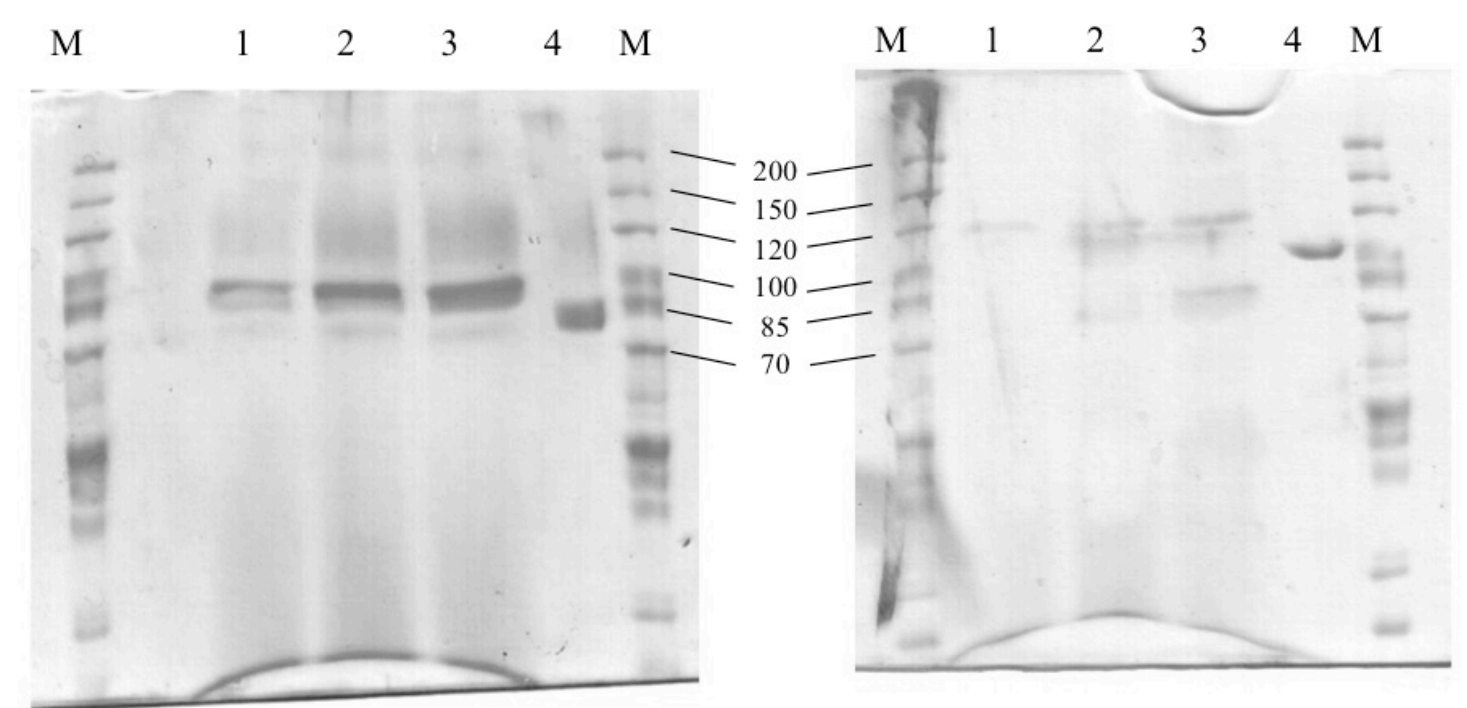

Figura 26. Géis de poliacrilamida $10 \%$ contendo alíquotas, concentradas cerca de 20 vezes, provenientes dos extratos das culturas de Bgl1 e Bgal, respectivamente, durante 3 dias de expressão. M- marcador de peso molecular; 1 a 3 alíquotas do primeiro ao quarto dia de expressão de Bgl1 (esquerda), que possui peso molecular de aproximadamente $79 \mathrm{kDa}$ e Bgal(direita) que possui peso molecular de aproximadamente $109 \mathrm{kDa}$; 4- alíquotas dos extratos de Bgl1 e Bgal após diálise e concentração. Foram aplicados no gel cerca de $10 \mu \mathrm{g}$ de cada proteína, baseando-se na dosagem pelo espectrofotômetro Nanodrop.

Apesar da visualização de algumas bandas contaminantes nos extratos provenientes da expressão, a diálise e a concentração dos extratos contribuíram para a predominância das proteínas Bgal e Bgl1 em seus respectivos extratos. Além disso, a dosagem de atividade específica de cada enzima, realizada pela hidrólise dos substratos sintéticos pNP- Gal e pNP-Glu, indicaram alta atividade específica de cada extrato (média de $7 \mathrm{U} / \mu \mathrm{L}$ para o extrato de Bgal e $12 \mathrm{U} / \mu \mathrm{L}$ para Bg11).

\subsection{Caracterização das enzimas livres e imobilizadas: eficiência da imobilização}

Para a imobilização de cada enzima individualmente, a incubação para a imobilização foi realizada sempre na proporção $100 \mu \mathrm{g}$ de enzima para $100 \mu \mathrm{L}$ de partículas, na presença do tampão fosfato de sódio $100 \mathrm{mM}, \mathrm{pH} 8,0$. Após o tempo de incubação, as partículas foram lavadas 3 vezes e ressuspendidas em $200 \mu \mathrm{L}$ de tampão. As reações de imobilização foram realizadas em triplicata. A quantidade de enzima imobilizada foi estimada a partir da mensuração da atividade específica no sobrenadantes e lavagens, determinando-se a quantidade de enzima ativa presente nas lavagens e portanto estimando-se a quantidade de enzima ativa remanescente nas nanopartículas pela subtração 
da quantidade que não foi ligada da quantidade de enzima que foi oferecida inicialmente às partículas.

No entanto, para algumas enzimas, notou-se que, quando diluídas, suas atividades específicas aumentavam, ao invés de diminuir e isso impossibilitava o cálculo da eficiência de imobilização, pois a cada lavagem a concentração de enzima na solução deveria diminuir, porém a atividade específica aparente aumentava. Tanto XegA quanto Bgll demonstraram este comportamento de aumento da atividade específica quando diluídas (dados não incluídos), portanto, para a estimativa da quantidade de enzima removida nas lavagens, foi utilizado o método de determinação de proteínas totais descrito por Read \& Northcote (1981). Este fenômeno de aumento da atividade específica de enzimas após diluições pode estar relacionado à capacidade de dissociação de enzimas multiméricas. Mais estudos de biofísica de proteínas poderão confirmar se realmente estas enzimas são multiméricas e se dissociam dentro destas determinadas condições.

$\mathrm{Na}$ Tabela 5, estão descritas as quantidades de enzima oferecidas às partículas, a quantidade de enzima que não foi ligada, proveniente do somatório da quantidade de enzima presente no sobrenadante e nas lavagens, a quantidade estimada de enzima imobilizada e a eficiência de imobilização, calculada como a porcentagem de enzima imobilizada. Na Tabela 6, as atividades específicas medidas para cada enzima, livres e imobilizadas, mensuradas em suas respectivas temperaturas ótimas.

Tabela 5. Média das quantidades de enzima oferecidas, não ligadas e imobilizadas e eficiência de imobilização.

\begin{tabular}{ccccc}
\cline { 2 - 4 } & $\begin{array}{c}\text { YicI } \\
(\mathrm{nmol})\end{array}$ & $\begin{array}{c}\text { XegA } \\
(\mathrm{nmol})\end{array}$ & $\begin{array}{c}\text { Bga1 } \\
(\mathrm{nmol})\end{array}$ & $\begin{array}{c}\text { Bgl1 } \\
(\mathrm{nmol})\end{array}$ \\
\hline Oferecida & 2,25 & 4,17 & 0,917 & 0,635 \\
Não ligada & 1,96 & 3,12 & 0,065 & 0,60 \\
Imobilizada & 0,298 & 1,057 & 0,852 & 0,035 \\
\hline Eficiência (\%) & $\mathbf{1 3 , 2}$ & $\mathbf{2 5 , 3}$ & $\mathbf{9 2 , 9}$ & $\mathbf{5 , 5}$ \\
Fonte: elaborado pela autora & & &
\end{tabular}

Pelos resultados demonstrados na tabela, as enzimas demonstraram eficiências de imobilização bastante diferentes. Enquanto que para a Bgl1 e YicI a eficiência de imobilização foi baixa, cerca de $5 \%$ e $13 \%$ do total de enzima oferecida foi efetivamente imobilizado, respectivamente, para Bgal a eficiência foi alta, pois quase $93 \%$ de toda enzima oferecida foi 
imobilizada nas partículas.

Tabela 6. Média das atividades específicas das enzimas livres e imobilizadas

\begin{tabular}{ccc}
\hline Enzima & $\begin{array}{c}\text { Atividade específica } \\
\left(\mathrm{U} \mathrm{nmol}^{-1}\right)-\text { livre }\end{array}$ & $\begin{array}{c}\text { Atividade específica } \\
\left(\mathrm{U} \mathrm{nmol}^{-1}\right)-\text { imobilizada }\end{array}$ \\
\hline YicI & 2,05 & 0,303 \\
XegA & 394,05 & 302,86 \\
Bga1 & 495,94 & 146,13 \\
Bgl1 & 998,25 & 66,08 \\
\hline
\end{tabular}

Média das atividades mensuradas nas temperaturas ótimas de cada enzima, livre e imobilizada. Fonte: elaborado pela autora

Por sua vez, a atividade específica para ambas as enzimas foi diminuída em relação à atividade específica mensurada antes da imobilização. Nota-se que, a eficiência de ligação pode variar muito de uma enzima para outra e que, independente desta eficiência de ligação, a imobilização é capaz de alterar a significativamente atividade catalítica de enzimas, neste caso diminuindo suas atividades. Foram consideradas as atividades específicas nas temperaturas ótimas de cada enzima após a imobilização.

Provavelmente a eficiência de ligação se relaciona com a estrutura tridimensional das enzimas e a disponibilidade de grupos reativos dos aminoácidos que participam da ligação covalente com a nanopartícula. É importante lembrar que YicI é uma enzima de estrutura hexamérica, enquanto Bgal é monomérica. Como já foi dito, algumas das enzimas parecem apresentar a característica de dissociação quando diluídas, o que faz com que sua atividade específica aumente.

\subsection{Caracterização das enzimas livres e imobilizadas: efeitos da temperatura}

Após reação de imobilização das enzimas individualmente nas nanopartículas, cada enzima acoplada ao nanomaterial teve sua temperatura ótima determinada, da mesma maneira que cada enzima livre em solução.

Para a enzima YicI acoplada ao nanomaterial, a temperatura ótima foi de $55^{\circ} \mathrm{C}$ (Figura 27), demonstrando um aumento de 10 graus em relação à temperatura ótima da YicI livre $\left(45^{\circ} \mathrm{C}\right) . \mathrm{O}$ perfil de atividade em relação à temperatura para a enzima YicI imobilizada foi relativamente bem distinto ao da enzima livre. Enquanto a atividade da enzima livre caiu bruscamente acima $\operatorname{dos} 45^{\circ} \mathrm{C}$, a enzima demonstrou atividade crescente de $40^{\circ} \mathrm{C}$ a $55^{\circ} \mathrm{C}$ e só decaiu em temperaturas acima de $55^{\circ} \mathrm{C}$. 


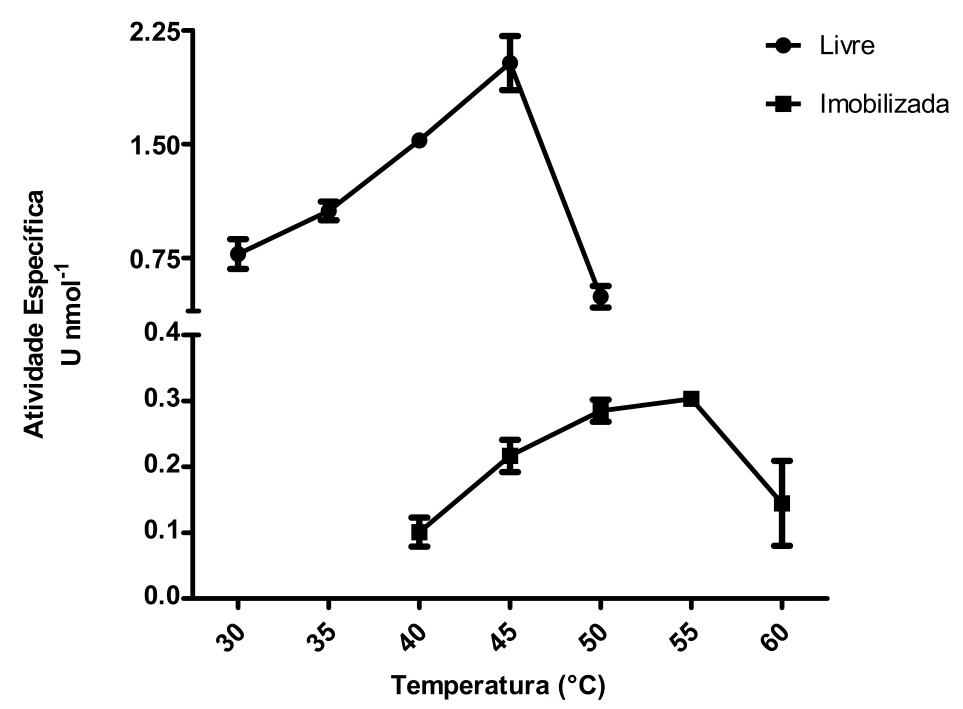

Figura 27. Curvas de temperatura ótima da enzima YicI livre e imobilizada. Fonte: elaborado pela autora

Para a enzima XegA imobilizada a temperatura ótima observada foi a mesma que da enzima livre, em torno de $65^{\circ} \mathrm{C}$ e o perfil de ambas foi bastante semelhante, com suas atividades decaindo em temperaturas superiores a $65^{\circ} \mathrm{C}$ (Figura 28).

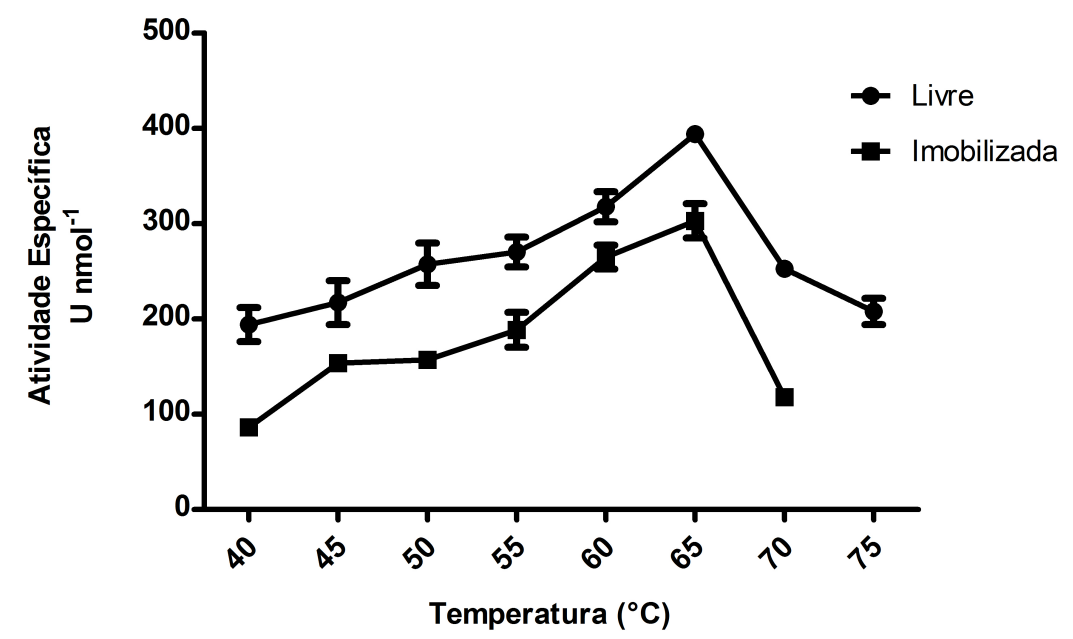

Figura 28. Curvas de temperatura ótima da enzima XegA livre e imobilizada. Fonte: elaborado pela autora

No caso da enzima Bgal imobilizada, sua temperatura ótima foi de $65^{\circ} \mathrm{C}$, a qual apesar de ser uma temperatura elevada, foi inferior à temperatura ótima da enzima Bgal livre $\left(75^{\circ} \mathrm{C}\right)$ (Figura 29). 


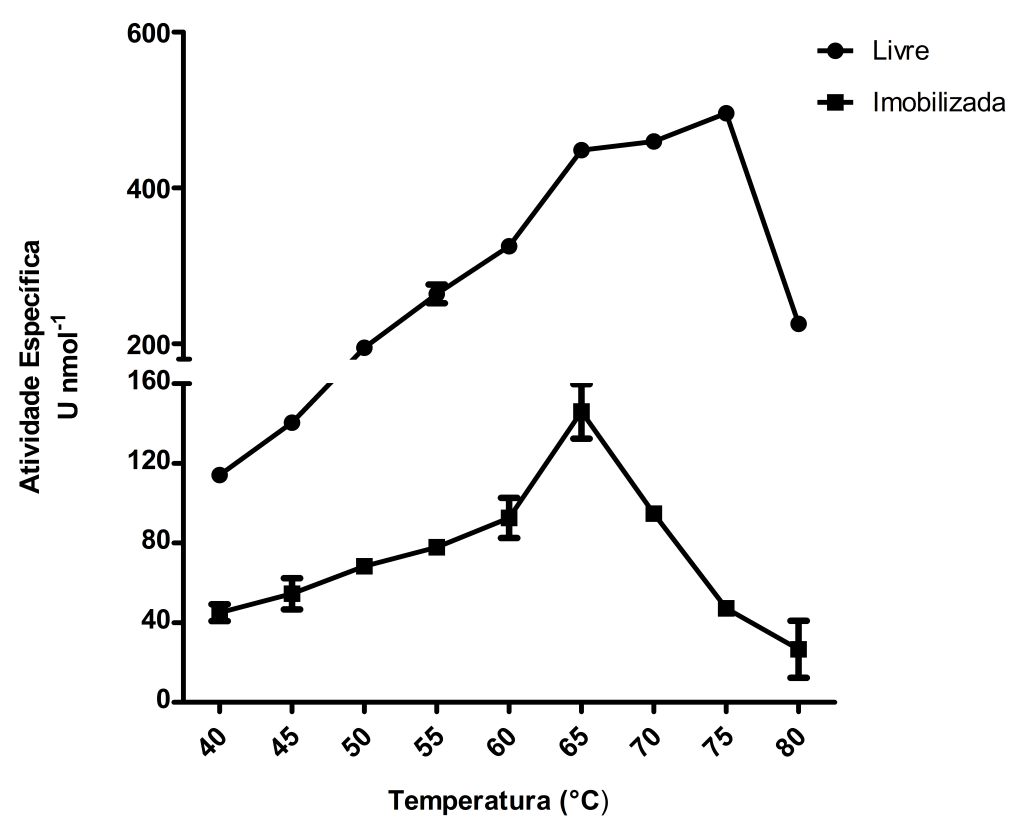

Figura 29. Curvas de temperatura ótima da enzima Bgal livre e imobilizada. Fonte: elaborado pela autora

Para a enzima Bgl1 imobilizada, sua temperatura ótima também foi de $65^{\circ} \mathrm{C}, 10$ graus a menos que a temperatura ótima determinada para a enzima livre $\left(75^{\circ} \mathrm{C}\right)$ (Figura 30$)$.

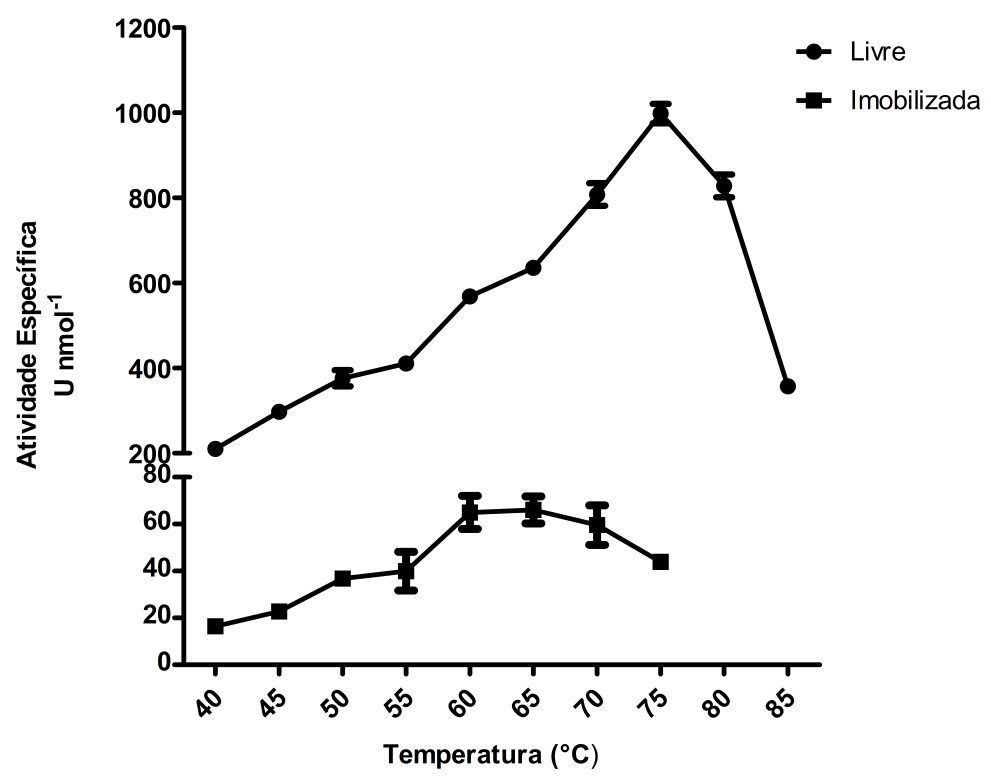

Figura 30. Curvas de temperatura ótima da enzima Bgl1 livre e imobilizada. Fonte: elaborado pela autora

Ambas as enzimas Bgal e Bgll na forma livre podem ser consideradas termofílicas, pois exibiram atividades máximas em temperaturas acima de $60^{\circ} \mathrm{C}$ e o decaimento da atividade foi observado somente em temperaturas superiores a $75^{\circ} \mathrm{C}$. Embora a imobilização dessas enzimas não tenha contribuído para o aumento da temperatura ótima, as temperaturas ótimas determinadas já 
foram relativamente altas (acima de $\left.60^{\circ} \mathrm{C}\right)$.

Assim, notou-se que apesar de as nanopartículas serem capazes de contribuir para o aumento da temperatura ótima de certas enzimas, dependendo provavelmente da estrutura tridimensional de cada enzima e como as ligações covalentes com o nanomaterial são formadas, a temperatura ótima de enzimas imobilizadas também pode ser diminuída.

\subsection{Caracterização das enzimas livres e imobilizadas: efeitos do pH}

Com relação ao pH ótimo das enzimas estudadas, no geral as enzimas imobilizadas demonstraram $\mathrm{pH}$ ótimo relativamente igual ou mais baixo que as enzimas livres.

Para a enzima YicI imobilizada o $\mathrm{pH}$ ótimo determinado foi muito próximo ao da enzima livre, ambas na faixa de $\mathrm{pH}$ 6,0 a 6,5 (Figura 31).

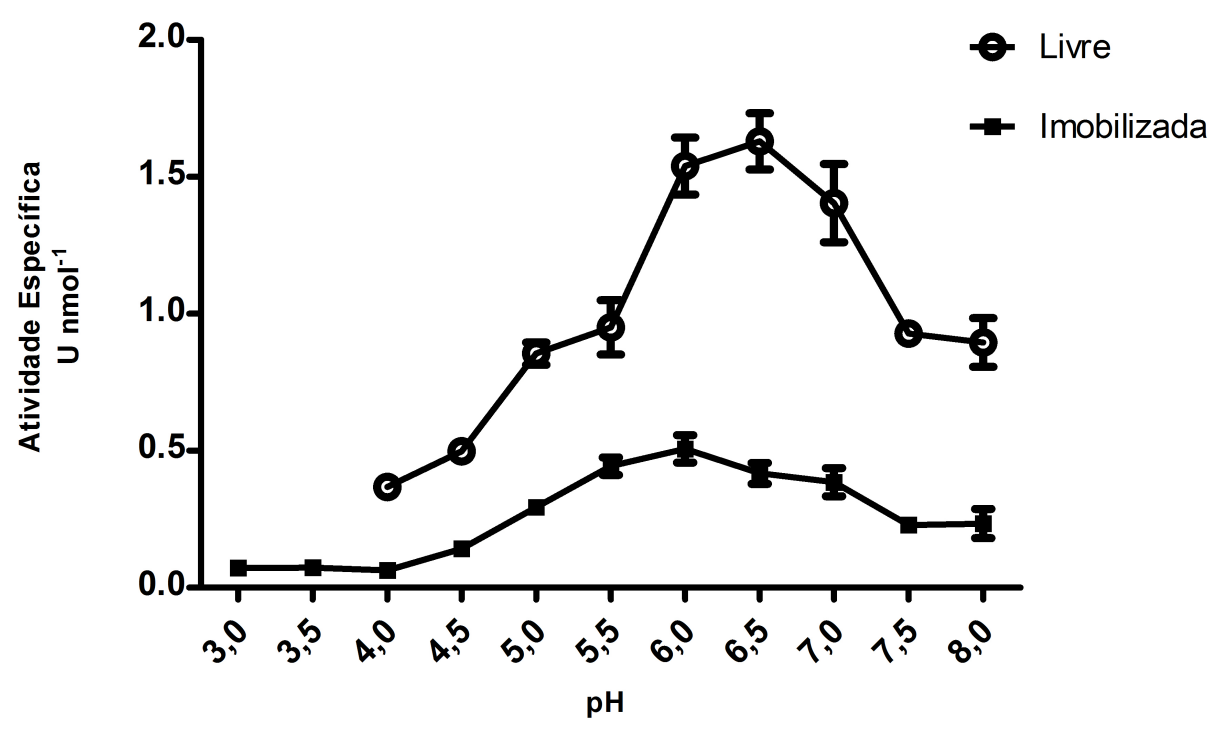

Figura 31. Curvas de pH ótimo da enzima YicI livre e imobilizada. Fonte: elaborado pela autora

A enzima XegA livre, demonstrou atividades específicas relativamente altas em $\mathrm{pH}$ ácido e o pH ótimo determinado foi 5,5, enquanto que a enzima imobilizada demonstrou ainda mais atividade em pH ácidos que a enzima livre, estando seu pH ótimo na faixa de 3,0 a 4,0 (Figura 32). 


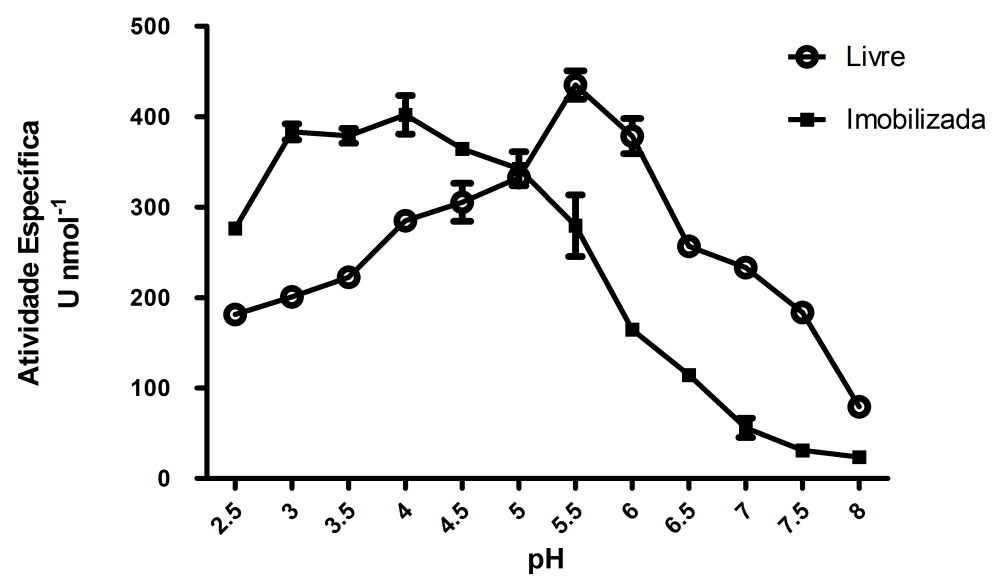

Figura 32. Curvas de pH ótimo da enzima XegA livre e imobilizada. Fonte: elaborado pela autora

Para a enzima Bga1, o pH ótimo determinado tanto para enzima livre quanto para imobilizada foram semelhantes, em torno de 4,0 e 4,5 (Figura 33).

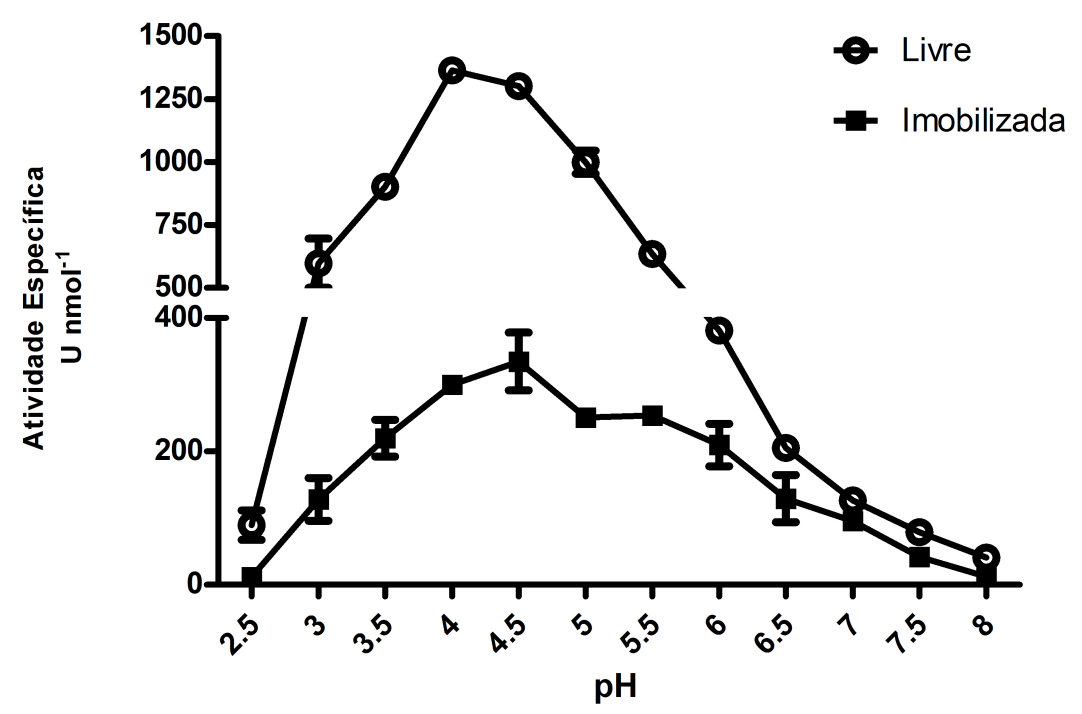

Figura 33. Curvas de pH ótimo da enzima Bga1 livre e imobilizada. Fonte: elaborado pela autora

Já, as atividades das enzimas Bgl1 livre e imobilizadas (Figura 34) foram máximas também na faixa de $\mathrm{pH}$ de 4,0 a 4,5, assim como Bga1. 


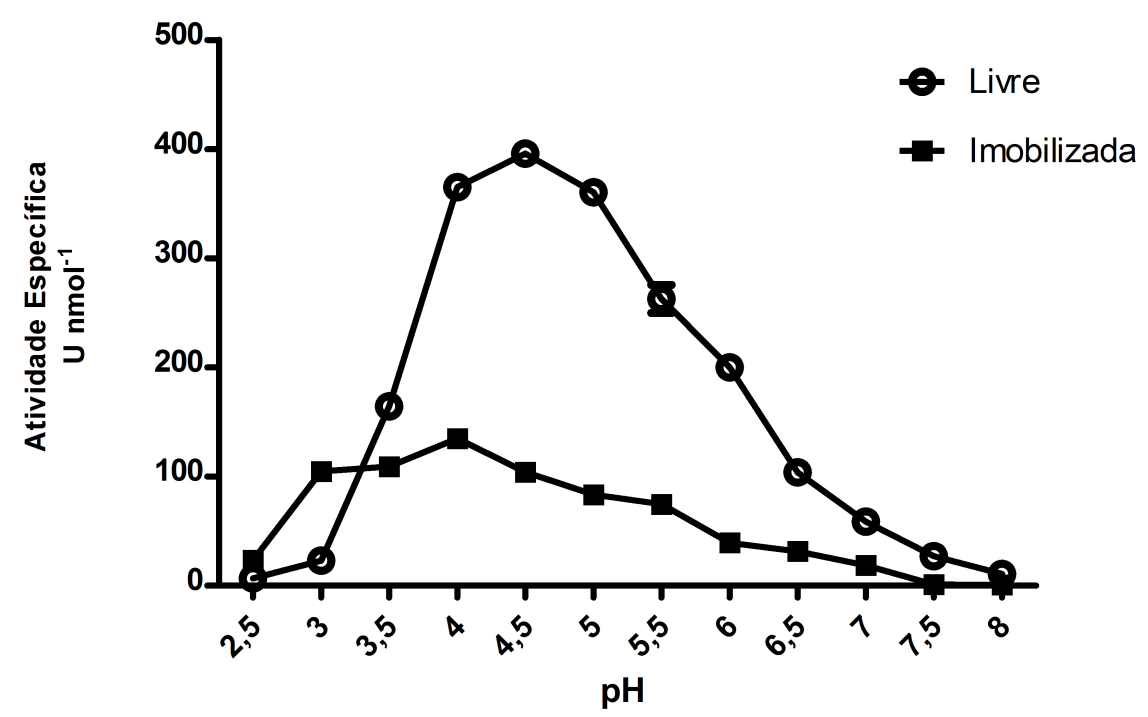

Figura 34. Curvas de pH ótimo da enzima Bgl1 livre e imobilizada. Fonte: elaborado pela autora

\subsection{Reuso das enzimas imobilizadas}

No estudo da reutilização das enzimas ligadas covalentemente às nanopartículas, foram realizados até dez ciclos de mensuração da atividade enzimática e lavagens (com tampão fosfato de sódio $50 \mathrm{mM}$, $\mathrm{pH} 8,0)$ sucessivas. As reações foram realizadas na temperatura e $\mathrm{pH}$ ótimos para cada enzima.

Para a enzima YicI foi possível determinar que a enzima mantém aproximadamente $80 \%$ da atividade após o terceiro ciclo e ainda cerca de 50\% após o quinto reuso. Apesar de a enzima demonstrar a tendência de manutenção de atividade residual para mais ciclos, a atividade específica mensurada foi muito baixa (média de $0,14 \mathrm{U}_{\mathrm{n} m o l}{ }^{-1}$ no quinto reuso). Por isso, optou-se pela realização do ensaio apenas até o quinto ciclo de reuso.

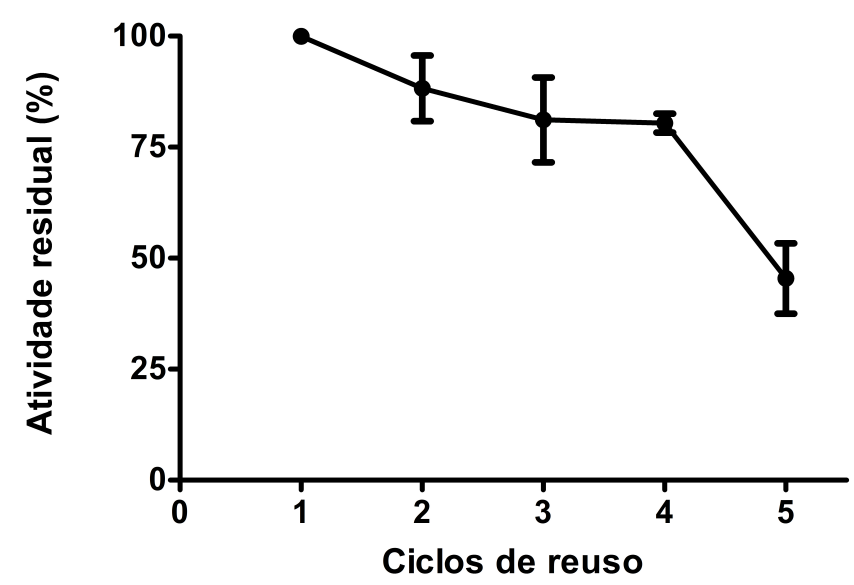

Figura 35. Atividade residual de YicI imobilizada em 5 ciclos de reuso. Fonte: Elaborado pela autora 
Para XegA, as lavagens após o primeiro uso do nanossistema se revelaram críticas pois a atividade decaiu drasticamente, chegando a aproximadamente $10 \%$ de atividade residual no segundo uso e praticamente nula no terceiro uso (Figura 36).

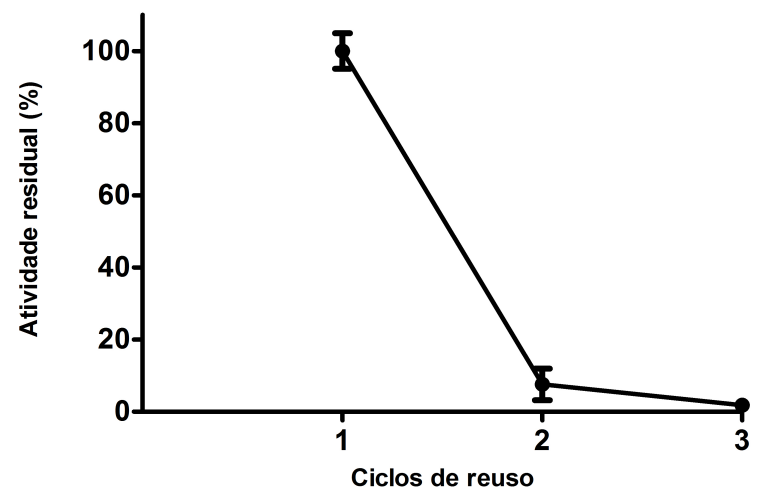

Figura 36. Atividade residual de XegA imobilizada em 3 ciclos de reuso. Fonte: elaborado pela autora

Assim como para a enzima XegA, para Bgl1 o reuso do nanomaterial também só foi analisado até o 3 ciclo devido ao drástico declínio da atividade residual após o primeiro uso. No segundo uso da Bgll imobilizada a atividade residual decaiu para menos de $20 \%$ e no terceiro ciclo, para aproximadamente 5\% (Figura 37).

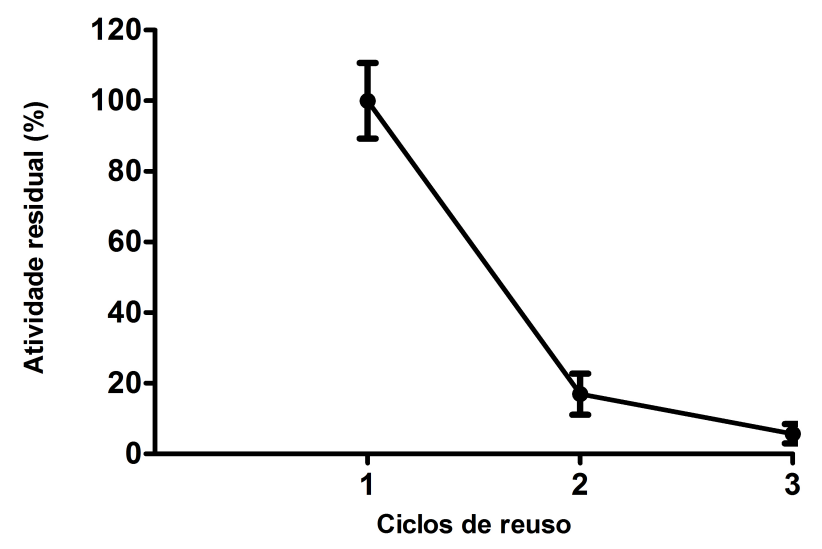

Figura 37. Atividade residual de Bgl1 imobilizada em de 3 ciclos de reuso. Fonte: elaborado pela autora

Por outro lado, a imobilização de Bgal nas nanopartículas resultou numa grande capacidade de reuso da enzima. Como demonstrado na Figura 38, enzima Bga1 acoplada às nanopartículas reteve atividade residual superior a $80 \%$ após 4 ciclos de reuso e ainda cerca de $50 \%$ 
após 10 ciclos. Apesar de o erro inerente às mensurações de atividade ter sido elevado, devido à dificuldade de padronização do volume de nanopartículas adicionado a cada replicata, os resultados ainda assim demonstraram uma capacidade de reutilização promissora, nos caso das nanopartículas acopladas com a enzima Bga1.

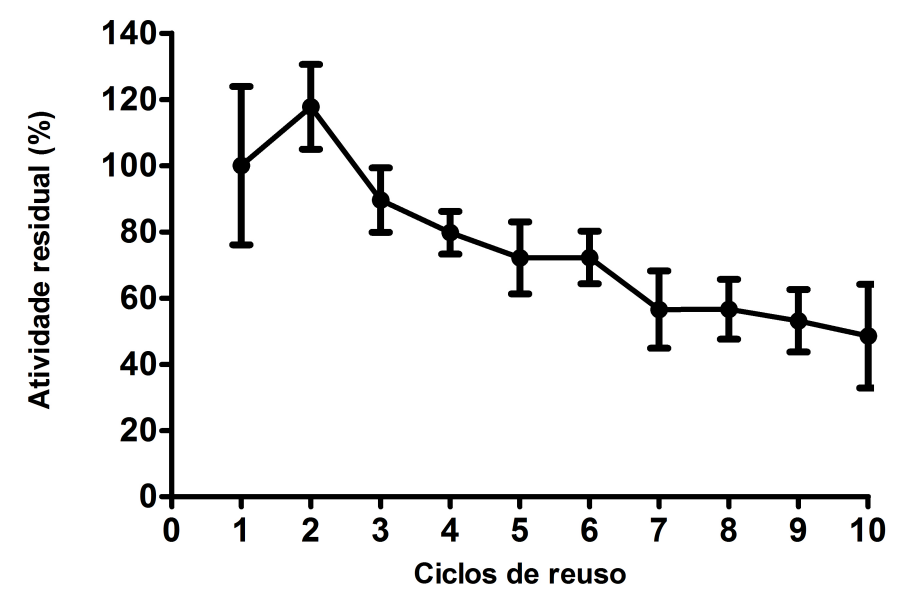

Figura 38. Atividade residual da Bgal imobilizada ao decorrer de 10 ciclos de reuso. Fonte: elaborado pela autora 
CAPÍTULO III

ESTUDOS DE OTIMIZAÇÃO DA PREPARAÇÃO DO SISTEMA NANOSESTRUTURADO PARA DESPOLIMERIZAÇÃO DO XILOGLUCANO 
III: Estudos de otimização da preparação do sistema nanoestruturado para despolimerização do xiloglucano

\section{MATERIAIS E MÉTODOS}

\subsection{Estudo preliminar da imobilização de XegA, YicI, Bga1 e Bgl1 em nanopartículas}

As enzimas XegA e YicI, ambas com cauda de histidina, e Bgal e Bgl1 foram aplicadas em diferentes combinações para estudos preliminares de imobilização das enzimas nas nanopartículas preparadas até o tratamento com glutaraldeído e sem adição do grupo AB-NTA-Ni ${ }^{2+}$, que tornariam as nanopartículas funcionalizadas para a imobilização de proteínas com cauda de histidina pela coordenação do anel imidazólico das histidinas com o $\mathrm{Ni}^{2+}$. Ao invés desse tipo de funcionalização, o glutaraldeído é capaz de formar ligações covalentes com as cadeias laterais de alguns aminoácidos. Assim, foram usadas quantidades equimolares (40 pmol) de cada enzima e $15 \mu \mathrm{L}$ de partículas previamente solubilizadas em tampão fosfato de sódio $100 \mathrm{mM}, \mathrm{pH}$ 8,0 para cada imobilização. As combinações de enzimas empregadas para imobilização nas nanopartículas podem ser resumidas na tabela a seguir. A imobilização ocorreu com a incubação das enzimas com as partículas a $4{ }^{\circ} \mathrm{C}$ durante 16 horas. Após esse período as partículas foram lavadas 3 vezes e ressuspendidas em tampão fosfato de sódio $50 \mathrm{mM} \mathrm{pH} \mathrm{8,0.}$

Tabela 7. Combinações de enzimas imobilizadas nas nanopartículas

\begin{tabular}{ll}
\hline A & XegA \\
\hline B & XegA + YicI \\
C & XegA + YicI + Bga1 \\
D & XegA + YicI + Bga1 + Bgll \\
\hline & Fonte: elaborado pela autora
\end{tabular}




\subsection{Análise da hidrólise do xiloglucano pelas enzimas imobilizadas no ensaio preliminar por Espectrometria de Massas e TLC}

Para os ensaios de hidrólise do xiloglucano, este substrato foi dissolvido em tampão acetato de amônio pH 6,0 na concentração de 0,5\%. Os ensaios com cada uma das combinações de enzima e o substrato xiloglucano foram compostos da seguinte forma: $12 \mu \mathrm{L}$ de nanopartículas (contendo uma das quatro combinações de enzimas imobilizadas) e $48 \mu \mathrm{L}$ de substrato pré aquecido a $40{ }^{\circ} \mathrm{C}$. As reações foram conduzidas a $40{ }^{\circ} \mathrm{C}$ por 3 horas e finalizadas por inativação térmica a $80{ }^{\circ} \mathrm{C}$ durante 5 minutos. Todas as reações para análise da degradação de xiloglucano com as enzimas também foram realizadas com enzimas livres. No caso das reações com enzimas livres, foram empregados $12 \mu \mathrm{L}$ de solução contendo as enzimas e diluídas em tampão fosfato de sódio $100 \mathrm{mM}$ pH 8,0 e $48 \mu \mathrm{L}$ de substrato. Todas as reações após a inativação foram congeladas e mantidas a $20^{\circ} \mathrm{C}$ para as análises posteriores por espectrometria de massas.

Para a análise por espectrometria de massas (ESI-MS), as reações foram descongeladas, centrifugadas e o sobrenadante foi coletado. Ao sobrenadente foi adicionada água Mili-Q até completar o volume de $150 \mu \mathrm{L}$ e cada amostra foi introduzida em vials para espectrometria de massas. Os experimentos de espectrometria de massas foram realizados usando um espectrômetro Xevo TQ-S MS (Waters Corporation, Milford, MA, USA) equipado com uma fonte de ionização eletrospray (ESI) operando em modo positivo e negativo. A análise foi realizada no modo "full scan". As condições típicas do ESI foram as seguintes: voltagem do capilar positivo $3,2 \mathrm{kV}$, voltagem do capilar negativo $2,5 \mathrm{kV}$, voltagem cone $40 \mathrm{~V}$, temperatura da fonte $50{ }^{\circ} \mathrm{C}$ e temperatura de dessovatação $\left(\mathrm{N}_{2}\right) 250^{\circ} \mathrm{C}$. O software MassLynx 4.0 (Waters Corporation, Milford, MA, USA) foi usado tanto para a aquisição dos dados quanto para o seu processamento.

Para a análise por cromatografia em camada delgada, ou TLC (Thin Layer Chromatography), as amostras das reações enzimáticas com foram concentradas com ácido tricloroacético (TCA) 20\% e então aplicadas na placa de sílica-gel (Merck, Darmstadt, Germany). Foram aplicados ao total, 10 $\mu \mathrm{L}$ de cada amostra na placa de sílica, porém adicionando-se $1 \mu \mathrm{L}$ de cada vez, com secagem total da amostra antes da aplicação seguinte. A fase móvel foi preparada com etil-acetato, ácido acético, ácido fórmico e água (9:3:1:4 v/v/v/v). Foram usados como padrões, glicose, xilose e galactose, na concentração $50 \mathrm{mM}$ cada. Os açúcares foram detectados com orcinol 0,4\% $\%(\mathrm{~m} / \mathrm{v})$ em ácido sulfúrico/álcool etílico $(1: 9 \mathrm{v} / \mathrm{v})$. 
1.3 Estudo de diferentes proporções enzimáticas para otimização da preparação do nanossistema

Após o estudo preliminar com as quatro combinações entra as enzimas em quantidades equimolares, foi desenvolvido um conjunto de diferentes proporções das quatro enzimas a serem imobilizadas nas nanopartículas. Essas combinações foram propostas como um modelo de planejamento fatorial e estão listadas na tabela a seguir:

Tabela 8 . Ensaios de diferentes proporções em pmol das enzimas livres e imobilizadas para hidrólise de xiloglucano

\begin{tabular}{rrrrr}
\hline \multicolumn{6}{c}{ Enzima (pmol) } & \multicolumn{1}{c}{ (picI } \\
\multicolumn{1}{c}{ Ensaio } & Bgl1 & \multicolumn{1}{c}{ Bgal } & \multicolumn{1}{l}{ XegA } & \multicolumn{1}{l}{ Yic } \\
$\mathbf{1}$ & 0 & 0 & 0 & 0 \\
$\mathbf{2}$ & 136 & 8 & 8 & 8 \\
$\mathbf{3}$ & 8 & 136 & 8 & 8 \\
$\mathbf{4}$ & 8 & 8 & 136 & 8 \\
$\mathbf{5}$ & 8 & 8 & 8 & 136 \\
$\mathbf{6}$ & 72 & 72 & 8 & 8 \\
$\mathbf{7}$ & 72 & 8 & 72 & 8 \\
$\mathbf{8}$ & 72 & 8 & 8 & 72 \\
$\mathbf{9}$ & 8 & 72 & 72 & 8 \\
$\mathbf{1 0}$ & 8 & 72 & 8 & 72 \\
$\mathbf{1 1}$ & 8 & 8 & 72 & 72 \\
$\mathbf{1 2}$ & 88 & 24 & 24 & 24 \\
$\mathbf{1 3}$ & 24 & 88 & 24 & 24 \\
$\mathbf{1 4}$ & 24 & 24 & 88 & 24 \\
$\mathbf{1 5}$ & 24 & 24 & 24 & 88 \\
$\mathbf{1 6}$ & 40 & 40 & 40 & 40 \\
\hline
\end{tabular}


Assim, para cada ensaio foram misturadas as quantidades de enzimas de acordo com a Tabela 8 , em tampão fosfato de sódio $100 \mathrm{mM}, \mathrm{pH} 8,0$, e adicionadas à $30 \mu \mathrm{L}$ de nanopartículas, ou $30 \mu \mathrm{L}$ de tampão, no caso dos ensaios com enzimas livres. O volume solução enzimática aplicado foi de $20 \mu \mathrm{L}$ e o volume total de cada ensaio de imobilização foi de $50 \mu \mathrm{L}$. Para a imobilização, esses ensaios foram incubados a $4^{\circ} \mathrm{C}$, por 3 horas. Após a incubação para imobilização, as partículas foram lavadas 3 vezes com tampão fosfato de sódio 50 mM, pH 8,0.

Para os ensaios de hidrólise do xiloglucano, este substrato foi dissolvido em tampão acetato de amônio pH 6,0 na concentração de 0,5\%. Cada um dos ensaios descritos na Tabela foi composto da seguinte forma: aproximadamente $30 \mu \mathrm{L}$ de nanopartículas (contendo as enzimas imobilizadas) e $70 \mu \mathrm{L}$ de substrato pré aquecido a $40^{\circ} \mathrm{C}$. As reações foram conduzidas a $40^{\circ} \mathrm{C}$ por 2 horas e finalizadas por inativação térmica a $80^{\circ} \mathrm{C}$ durante 5 minutos. Todas as reações para análise da degradação de xiloglucano com as enzimas também foram realizadas com enzimas livres. No caso das reações com enzimas livres, foram empregados $30 \mu \mathrm{L}$ de solução contendo as enzimas diluídas em tampão fosfato de sódio $100 \mathrm{mM}, \mathrm{pH}$ 8,0 e $70 \mu \mathrm{L}$ de substrato. Todas as reações após inativadas foram congeladas e mantidas a $-20^{\circ} \mathrm{C}$ para as análises posteriores. Todas a reações foram realizadas em triplicata.

\subsection{Quantificação da hidrólise do xiloglucano pela mensuração de glicose liberada}

Como uma forma de quantificação da hidrólise do xiloglucano nos ensaios com enzimas imobilizadas ou livres, uma alíquota de cada produto desses ensaios foi submetida à determinação da glicose livre, pelo teste colorimétrico contendo glicose oxidase do kit Glicose Liquiform (Labtest). Uma alíquota de 5 a $20 \mu \mathrm{L}$ de cada reação foi adicionada à $100 \mu \mathrm{L}$ do reagente contendo a glucose oxidase e mantidos à temperature ambiente por 20 minutos. Em seguida, essas reações tiveram suas absorbâncias determinadas à $505 \mathrm{~nm}$, em microplacas de acrílico, em um espectrofotômetro leitor de microplacas (Molecular Devices). A quantidade de glicose liberada em cada reação foi calculada por interpolação a partir de uma curva padrão feita com a mistura de diferentes concentrações de glicose e o reagente e suas respectivas abosrbâncias a $505 \mathrm{~nm}$ em reações de volume final $120 \mu \mathrm{L}$. 


\subsection{Análise da hidrólise do xiloglucano por ESI-MS}

Para os ensaios de hidrólise do xiloglucano, este substrato foi dissolvido em tampão acetato de amônio pH 6,0 na concentração de $0,5 \%$. Os ensaios com cada uma das combinações de enzimas e o substrato xiloglucano, extraído de sementes de Jatobá (Hymenaea courbaril), foram descritos no item 1.3 deste capítulo. Todas as reações de hidrólise foram conduzidas a $40^{\circ} \mathrm{C}$ por 2 horas e finalizadas por inativação térmica a $80^{\circ} \mathrm{C}$ durante 5 minutos. Após a inativação, os produtos das reações foram congelados e mantidos a $-20^{\circ} \mathrm{C}$. Antes da análise por ESI-MS, as reações foram descongeladas, centrifugadas e o sobrenadante foi coletado. A cada sobrenadente foi adicionada água Mili-Q até completar o volume de $150 \mu \mathrm{L}$ e cada amostra foi introduzida em tubos (vials) para espectrometria de massas. Os experimentos foram conduzidos no espectrômetro de massas da mesma maneira descrita no ítem 1.2 deste capítulo.

\subsection{Reuso dos nanosistemas para a hidrólise do xiloglucano}

Após análise dos resultados da hidrólise do xiloglucano pelos ensaios enzimáticos contendo diferentes quantidades de cada enzima, alguns desses ensaios foram selecionados para terem sua capacidade de reuso avaliadas. Assim os nanosistemas foram montados seguindo o esquema de proporções descrito no item 1.3, no entanto foram oferecidas 3 vezes mais enzimas para uma quantidade 3 vezes maior de partículas. Por exemplo, para o ensaio de número 7 (72 pmol de Bgl1, 8 pmol de Bga1, 72 pmol de XegA, 8 pmol de YicI), com o aumento de 3 vezes, foram oferecidos 216 pmol de Bgl1, 24 pmol de Bga1, 216 pmol de XegA e 24 pmol de YicI, previamente diluídas em tampão fosfato de sódio $100 \mathrm{mM} \mathrm{pH} \mathrm{8,0.} \mathrm{Um} \mathrm{total} \mathrm{de} 210 \mathrm{uL}$ contendo as devidas quantidades de enzimas e tampão foi misturado a $90 \mu \mathrm{L}$ de nanopartículas em reações de imobilização de 16 horas, mantidas a $4^{\circ} \mathrm{C}$ e realizadas em triplicata. Após a imobilização e lavagens, cada ensaio contendo os nanossistemas híbridos foi incubado com $110 \mu \mathrm{L}$ de xiloglucano $0,5 \%$ previamente dissolvido em tampão McIlvaine $\mathrm{pH}$ 6,0, em ciclos de reações de hidrólise de 90 minutos, realizadas em banho-maria a $50^{\circ} \mathrm{C}$.

Após o tempo de hidrólise, cada reação foi separada das partículas com um imã e incubada a $80^{\circ} \mathrm{C}$ para inativação. Os produtos de cada reação de hidrólise foram submetidos a dosagem de glicose liberada com o kit Glicose Liquiform (Labtest), portanto a atividade de cada ciclo de reuso foi expressa em forma de glicose liberada. 


\section{RESULTADOS}

\subsection{Estudo preliminar da imobilização covalente de XegA, YicI, Bga1 e Bgl1 e análise da degradação do xiloglucano por ESI-MS e TLC}

A imobilização das enzimas neste estudo preliminar foi realizada via ligação covalente e após a imobilização dos diferentes conjutos de enzimas, estes foram empregados em ensaios de degradação do xiloglucano.

Tendo como referência estudos que aplicaram a espectrometria de massas para análise dos padrões de oligossacrídeos liberados na degradação do xiloglucano (VINUEZA et al., 2013) (ver Tabela 9), foi possível identificar vários oligossacarídeos característicos do xiloglucano, derivados da ação das enzimas, tanto aplicadas na forma livre como na forma imobilizada, indicando que as enzimas imobilizadas continuaram ativas e atuaram em conjunto na despolimerização do xiloglucano. Inclusive, quando as quatro enzimas foram aplicadas juntas, foi possível identificar a liberação de monômeros de xilose, galactose e glicose (Figura 39).

Interessantemente, também foi possível identificar picos referentes a dissacarídeos celobiose (pico 365 como aduto de sódio), xilose-glicose ou xilose-galactose (pico 335, como aduto de sódio) e também xilobiose (pico 305 como aduto de sódio). É importante notar que a presença de xilobiose no produto de reação não pode ser proveniente da despolimerização do xiloglucano, mas pode ser o resultado de uma reação de transglicosilação, ou tranxilosilação, realizada por alguma das enzimas presentes. Existem evidências de que enzimas $\alpha$-xilosidases também possuem atividade de transxilosilação (KANG et al., 2007; MORACCI et al., 2000), portanto provavelmente a enzima YicI foi responsável por promover a formação desses dissacarídeos de xilose. 
Tabela 9. Principais oligômeros que formam o xiloglucano de Jatobá, suas respectivas notações, massas moleculares $(\mathrm{MM})$, massas como adutos de sódio $\left(\mathrm{M}+{ }^{23} \mathrm{Na}\right)$, de amônio $\left(\mathrm{M}+{ }^{18} \mathrm{NH}_{4}\right)$ e de potássio $\left(\mathrm{M}+{ }^{39} \mathrm{~K}\right)$.

\begin{tabular}{|c|c|c|c|c|c|}
\hline Oligômero & Notação & MM (Da) & {$[\mathrm{M}+\mathrm{Na}]^{+}$} & {$\left[\mathbf{M}+\mathbf{N H}_{4}\right]^{+}$} & {$[\mathbf{M}+\mathbf{K}]^{+}$} \\
\hline $\begin{array}{lc}\text { Xyl } & \text { Xyl } \\
\text { Gle }- \text { Gle }- \text { Gle }- \text { Gle } & \text { Xyl }\end{array}$ & $\mathrm{XXXG}$ & 1062 & 1085 & 1080 & 1101 \\
\hline $\begin{array}{c}\text { Xyl } \\
\text { Gle }- \text { Gle }- \text { Xyl } \\
\text { Xyl } \\
\text { Xal }- \text { Gle } \\
\text { Gal }\end{array}$ & XLXG & 1224 & 1247 & 1242 & 1263 \\
\hline 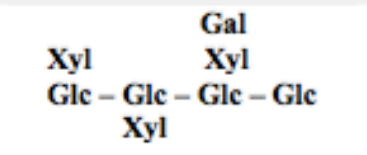 & XXLG & 1224 & 1247 & 1242 & 1263 \\
\hline \begin{tabular}{lc} 
Xyl & Gal \\
Gle - Gle & Xyl \\
\multicolumn{2}{c}{ Xyl } \\
\multicolumn{2}{c}{ Gle - Glc } \\
Gal
\end{tabular} & XLLG & 1386 & 1409 & 1404 & 1425 \\
\hline 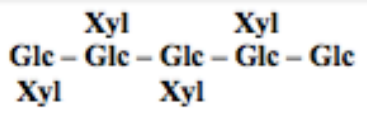 & $\mathrm{XXXXG}$ & 1356 & 1379 & 1374 & 1395 \\
\hline \begin{tabular}{lll} 
Xyl & \multicolumn{2}{c}{ Xyl } \\
Gle - Gle - Gle & - Gle - Gle \\
\multicolumn{1}{l}{ Xyl } & Xyl \\
& Gal &
\end{tabular} & XLXXG & 1518 & 1541 & 1536 & 1557 \\
\hline 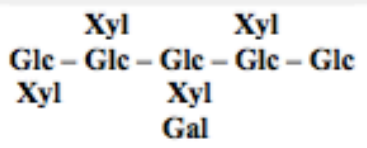 & XXLXG & 1518 & 1541 & 1536 & 1557 \\
\hline 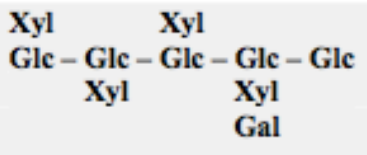 & XXXLG & 1518 & 1541 & 1536 & 1557 \\
\hline 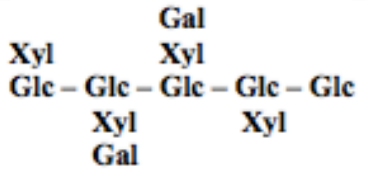 & XLLXG & 1680 & 1703 & 1698 & 1719 \\
\hline 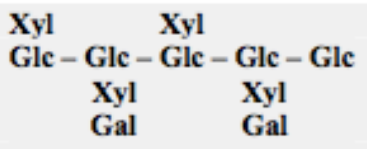 & XLXLG & 1680 & 1703 & 1698 & 1719 \\
\hline 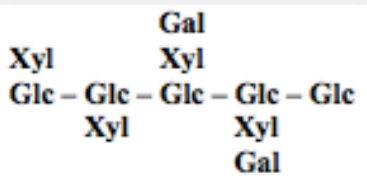 & XXLLG & 1680 & 1085 & 1080 & 1719 \\
\hline 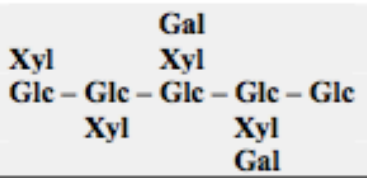 & XXLLG & 1680 & 1085 & 1080 & 1719 \\
\hline
\end{tabular}

Fonte: (CARNEIRO, 2017) 


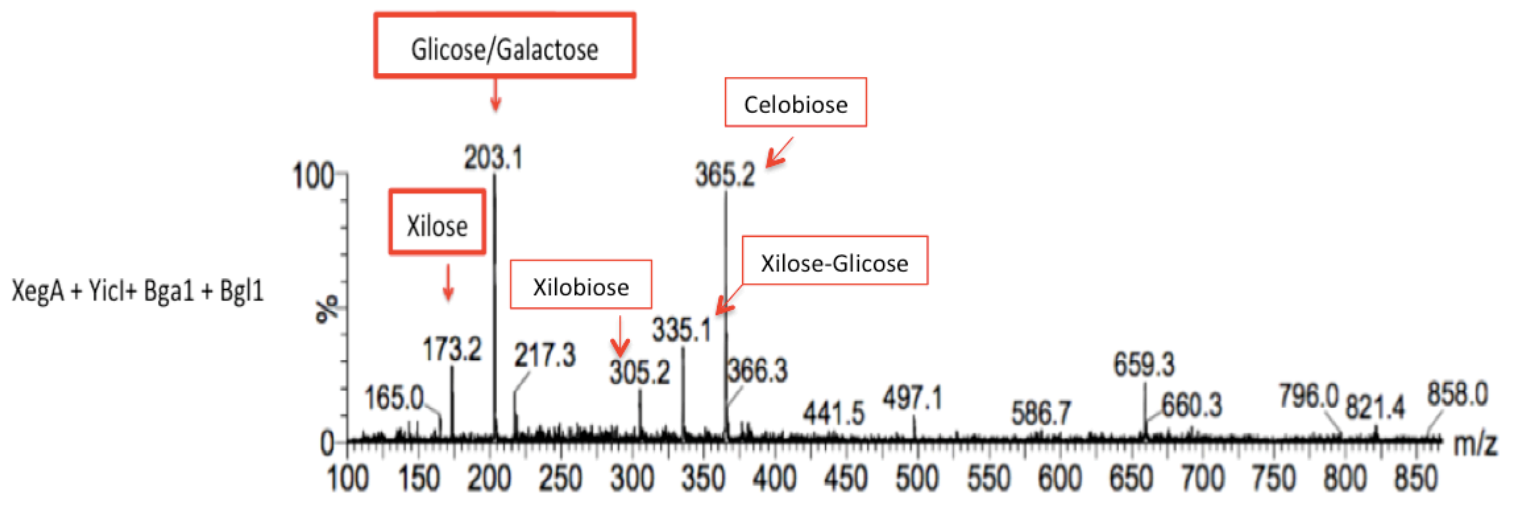

Figura 39. Espectros de massa dos produtos da hidrólise do xiloglucano com as quatro enzimas imobilizadas. Em destaque os picos de razão $\mathrm{m} / \mathrm{z}$ correspondentes à massa de monômeros de xilose, na forma de adutos de sódio (173 Da) e glicose ou galactose, também como adutos de sódio (203 Da). Também estão identificados picos referentes aos dissacarídeos xilobiose (305 Da), xilose-glicose (335 Da) e celobiose (365 Da). Fonte: elaborado pela a autora.

Com os espectros de massas foi possível identificar a ação sequencial das enzimas. Nos resultados dos ensaios apenas com a enzima XegA foi possível identificar os picos de massas referentes a oligossacarídeos de 6 a 4 resíduos, em seguida, com ação de XegA e YicI, foi possível identificar massas que correspondem aos oligossacarídeos liberados por XegA subtraídos de uma massa correspondente a um resíduo de xilose, $132 \mathrm{Da}$. De forma semelhante, com a ação das enzimas XegA, YicI e Bgal foi possível identificar picos correspondentes a oligossacarídeos subtraídos da massa de um resíduo de galactose, 162 Da (Figura 40). 


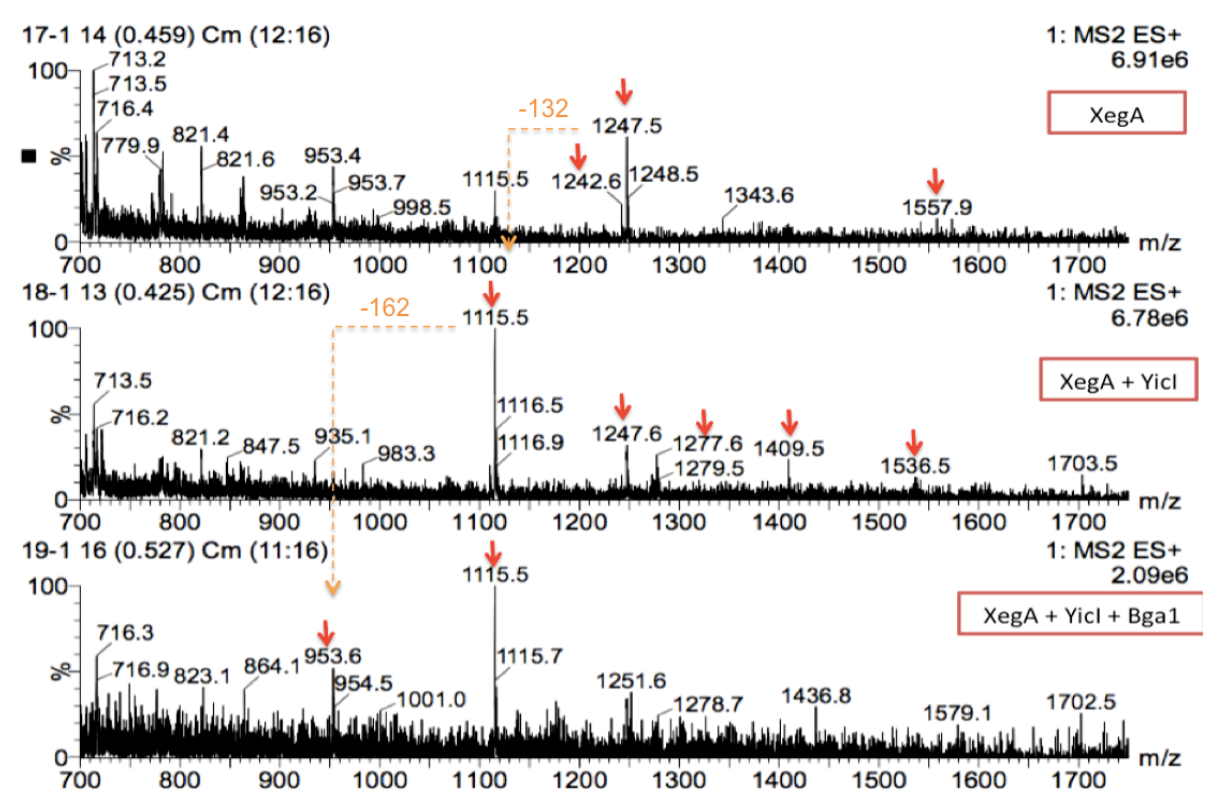

Figura 40. Espectros de massa dos produtos da degradação do xiloglucano pelas enzimas imobilizadas nas nanopartículas. Em destaque, oligossacarídeos característicos da hidrólise de xiloglucano, podendo ser notado o decréscimo de 132 Da quando há perda de resíduo de xilose e de 162 Da quando há remoção de resíduo de galactose. Fonte: elaborado pela a autora.

Na Figura 40, observa-se que com a ação de XegA detectou-se a presença dos picos de razão $\mathrm{m} / \mathrm{z}$ 1242, 1247 e 1557, os quais podem corresponder aos oligômeros XXLG, XLXG ou XLXXG/XXLXG/XXXLG, respectivamente, sendo que alguns desses oligômeros estão presentes como adutos de sódio, de amônio ou de potássio. Com a ação de XegA e YicI, notou-se a presença do pico 1115 que pode corresponder ao pico de m/z 1247 subtraído de 132 Da, a massa de um resíduo de xilose, indicando que houve remoção de xilose por YicI dos oligômeros liberados por XegA. O pico m/z 1115 pode corresponder, portanto aos oligômeros GLXG/GXLG com adutos de sódio, pois são derivados dos oligômeros XLXG/ XXLG que perderam um resíduo de xilose. Da mesma forma, o pico $\mathrm{m} / \mathrm{z} 1277$ (GLLG) corresponde ao pico $\mathrm{m} / \mathrm{z} \quad 1409$ (GXXLG/GXLXG/GLXXG) subtraído de um resíduo de xilose. Ainda como resultado da ação de XegA e YicI, foi possível identificar também picos de razão m/z 1247 e 1536, que correspondem a respectivamente, XXLG/XLXG com aduto de sódio e XLXXG/XXLXG com aduto de amônio.

Finalmente, com a ação das enzimas XegA, YicI e Bga1 juntas, foi possível identificar a presença do pico de razão m/z 953, o qual corresponde ao pico m/z 1115 subtraído de 162 Da, o que corresponde a retirada de um resíduo de galactose por Bga1. Portanto, o pico m/z 953 provavelmente corresponde ao oligômero GXXG com aduto de sódio. Também foi possível 
identificar novamente a presença do pico m/z 1115 (GLXG/GXLG).

Por sua vez, o resultado do TLC corrobora com os resultados obtidos pela espectrometria de massas, uma vez que foi possível identificar bandas correspondentes a oligossacarídeos liberados pela ação das enzimas imobilizadas e livres, incluindo também bandas que correspondem aos monômeros de glicose, galactose e xilose (Figura 41). Entretanto, a análise do resultado do TLC também revelou uma diferença de intensidade entre as bandas referentes à ação das enzimas livres e as enzimas imobilizadas. Isso provavelmente se deve ao fato de que nem toda a quantidade de proteínas oferecidas às partículas na imobilização é realmente imobilizada, e uma quantidade significativa das enzimas é perdida nas lavagens. Dessa forma, nos ensaios de hidrólise, a quantidade real de enzimas livres foi maior que a quantidade de enzimas imobilizadas. Apesar disso, esses ensaios preliminares foram úteis em demonstrar que as quatro enzimas imobilizadas permaneceram ativas e atuaram em conjunto na despolimerização completa do xiloglucano.

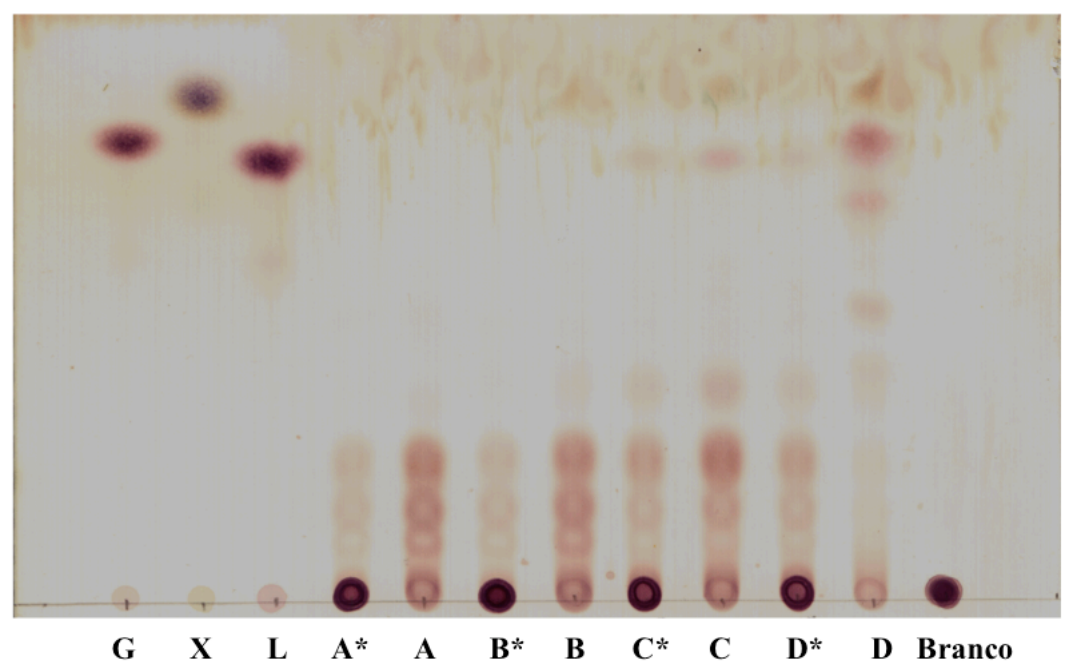

Figura 41. Resultado da cromatografia em camada delgada, TLC, dos produtos da degradação do xiloglucano de Jatobá pelas enzimas livres e imobilizadas. G- padrão de glicose; X-padrão de xilose; L- padrão de galactose; AXegA; A*- XegA imobilizada; B- XegA + YicI; B* - XegA + YicI imobilizadas; C- XegA + YicI + Bga1; C* - XegA + YicI + Bga1 imobilizadas; D- XegA + YicI + Bga1 + Bgl1; D* - XegA + YicI + Bga1 + Bgl1 imobilizadas. Fonte: a autora

\subsection{Estudo da imobilização de diferentes proporções enzimáticas para a hidrólise do xiloglucano}

Como descrito na Tabela 8, diferentes proporções enzimáticas foram aplicadas, na forma livre e acopladas nas nanopartículas, em reações de hidrólise do xiloglucano. A hidrólise do polissacarídeo foi analisada através da mensuração de glicose liberada, por um ensaio colorimétrico 
contendo a enzima Glicose Oxidase. Assim, a Figura 42 expressa a quantidade de glicose liberada em cada ensaio de hidrólise. O ensaio 1 se trata do controle negativo, o qual continha apenas substrato e tampão e o ensaio 16 se trata do ensaio contendo quantidades equimolares de cada enzima.

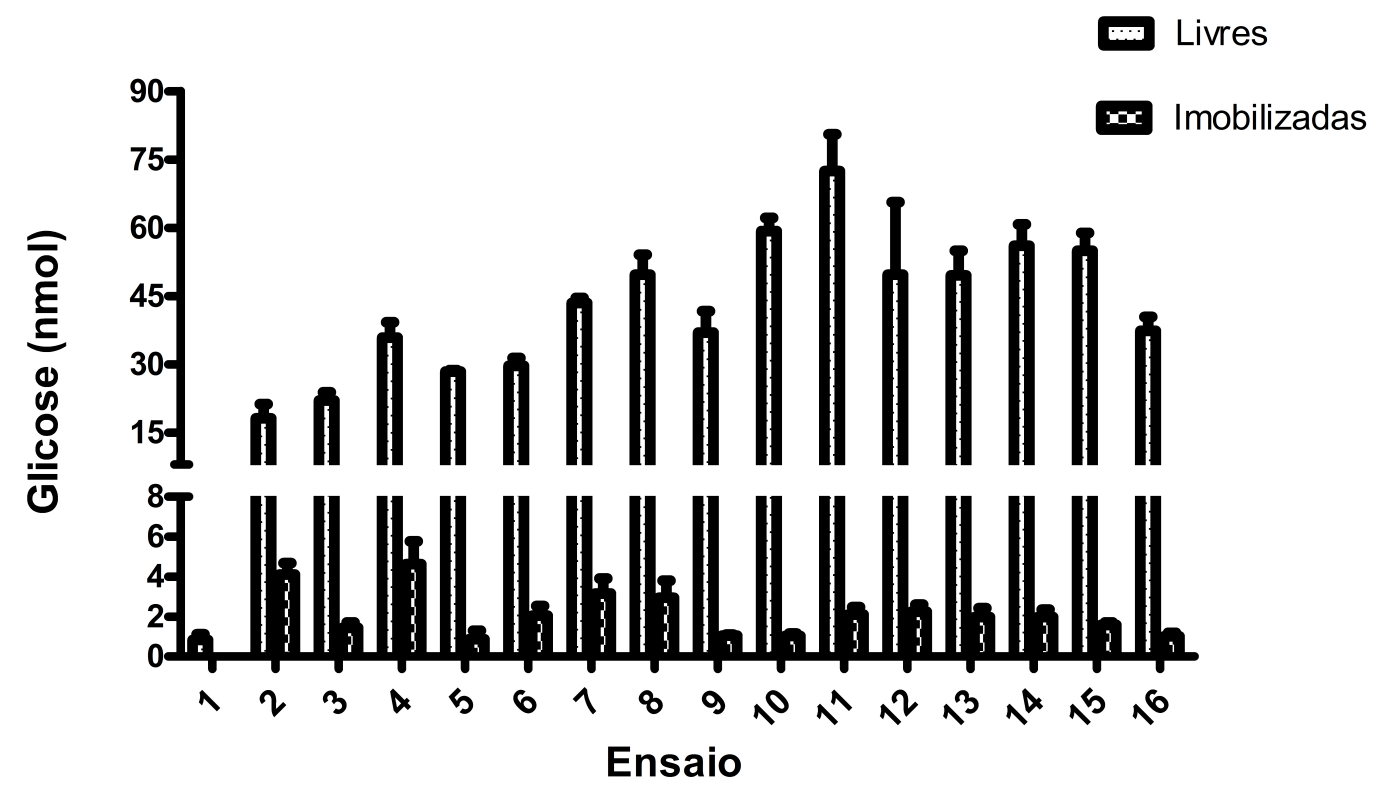

Figura 42. Quantidade de glicose liberada em cada ensaio contendo diferentes proporções das enzimas livres ou imobilizadas. Fonte: elaborado pela autora

No caso dos grupos de ensaios contendo enzimas livres foi possível notar que os ensaios que continham maior proporção de enzima XegA ou Bgll ou de ambas (ensaios 4, 7 e 11) foram mais eficientes na liberação de glicose. Apesar da grande diferença em termos de quantidade de glicose liberada, foi possível notar a mesma relação nos grupos de ensaios com enzimas imobilizadas. Os ensaios 2, 4 e 7 das enzimas imobilizadas também demonstraram liberação de glicose mais elevada, comparados ao demais e além disso, os ensaios 11, 12, 13 e 14 também se destacaram.

Não foi possível mensurar a quantidade de enzima efetivamente imobilizada nas partículas em cada ensaio, a quantidade considerada foi a quantidade oferecida às partículas antes da imobilização. Por isso, as baixas quantidades de glicose liberada nesses ensaios, em comparação com os ensaios contendo enzimas livres, deve-se principalmente à baixa eficiência de imobilização de enzimas nas partículas. Mas além disso, o fato de as enzimas imobilizadas apresentarem atividades diminuídas com a imobilização, algumas apresentando uma atividade específica bem inferior, como a YicI, impacta diretamente na quantidade de produto final da reação de hidrólise mensurado neste experimento, neste caso a glicose. Ou seja, como este experimento mensura a quantidade do produto final da hidrólise do xiloglucano e uma vez que todas as enzimas têm papel 
na despolimerização completa do polissacarídeo, a diminuição das suas atividades também diminui diretamente a quantidade dos produtos finais liberados.

Já foi visto que para cada enzima, existe uma eficiência de imobilização diferente. Apesar de não ser possível calcular a eficiência de imobilização de cada ensaio, todos eles apresentaram liberação de glicose superior à quantidade de glicose mensurada no ensaio 1 (controle), demonstrando que por menor que tenha sido a eficiência de imobilização, ainda assim, houve quantidade suficiente de enzima imobilizada, as quais permaneceram ativas contra o xiloglucano após a imobilização, contribuindo para a sua despolimerização.

Este experimento foi idealizado como um screening das proporções ótimas das enzimas necessárias para a hidrólise do xiloglucano. O passo seguinte, consistiu na seleção de alguns desses ensaios para a análise da hidrólise do xiloglucano com a técnica de espectrometria de massas.

\subsection{Análise da hidrólise do xiloglucano por ESI-MS}

Os produtos da reação de hidrólise do xiloglucano dos seguintes ensaios enzimáticos foram submetidos a análise por espectrometria de massas: 2, 4, 7, 8 e 14 (ver tabela 8). Foram analisados tanto os ensaios com as enzimas imobilizadas quanto os ensaios com as enzimas livres.

Em todos os produtos de reação analisadas foi possível visualizar pelo menos um dos picos de razão m/z referentes a xilose (168 como aduto de amônio, ou 173 como aduto de sódio, ou 189 como aduto de potássio) e aos isômeros glicose/galactose (198 como aduto de amônio, ou 203 como aduto de sódio, ou 219 como aduto de potássio), ou seja, embora não se qualifique como um resultado quantitativo da liberação de monossacarídeos, os espectros de massa parecem indicar que houve despolimerização completa do xiloglucano, devido a presença desses monossacarídeos nos produtos da hidrólise. 


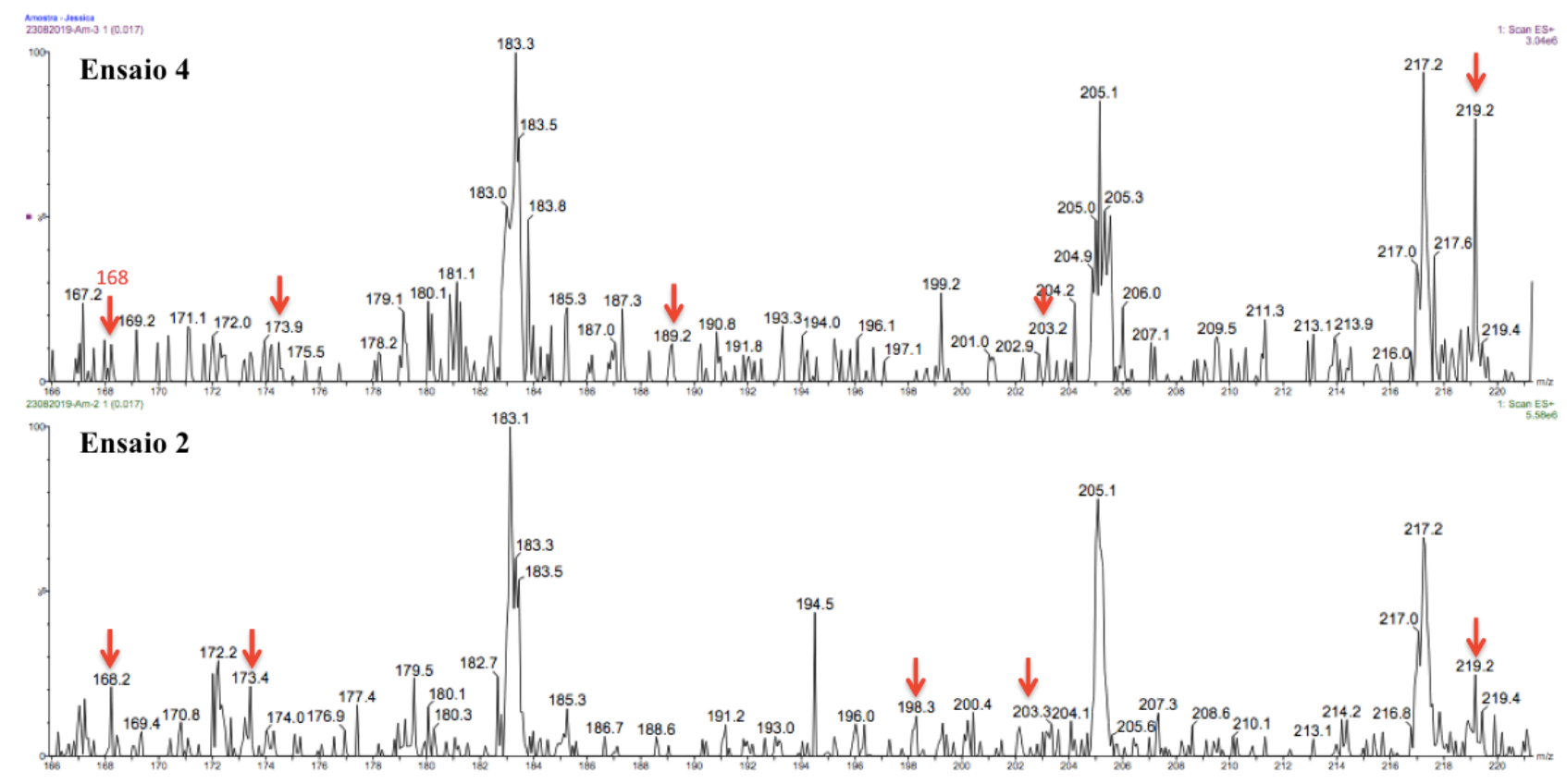

Figura 43. Espectros de massa dos produtos da hidrólise do xiloglucano com os ensaios 2 e 4 . Em destaque os picos de razão m/z correspondentes à massa de monômeros de xilose (na forma de adutos de amônio - 168 Da, de sódio -173 Da, e de potássio- 189 Da) e glicose ou galactose (como adutos de amônio- 198 Da, de sódio - 203 Da e de potássio- $219 \mathrm{Da}$ ). Fonte: elaborado pela a autora.

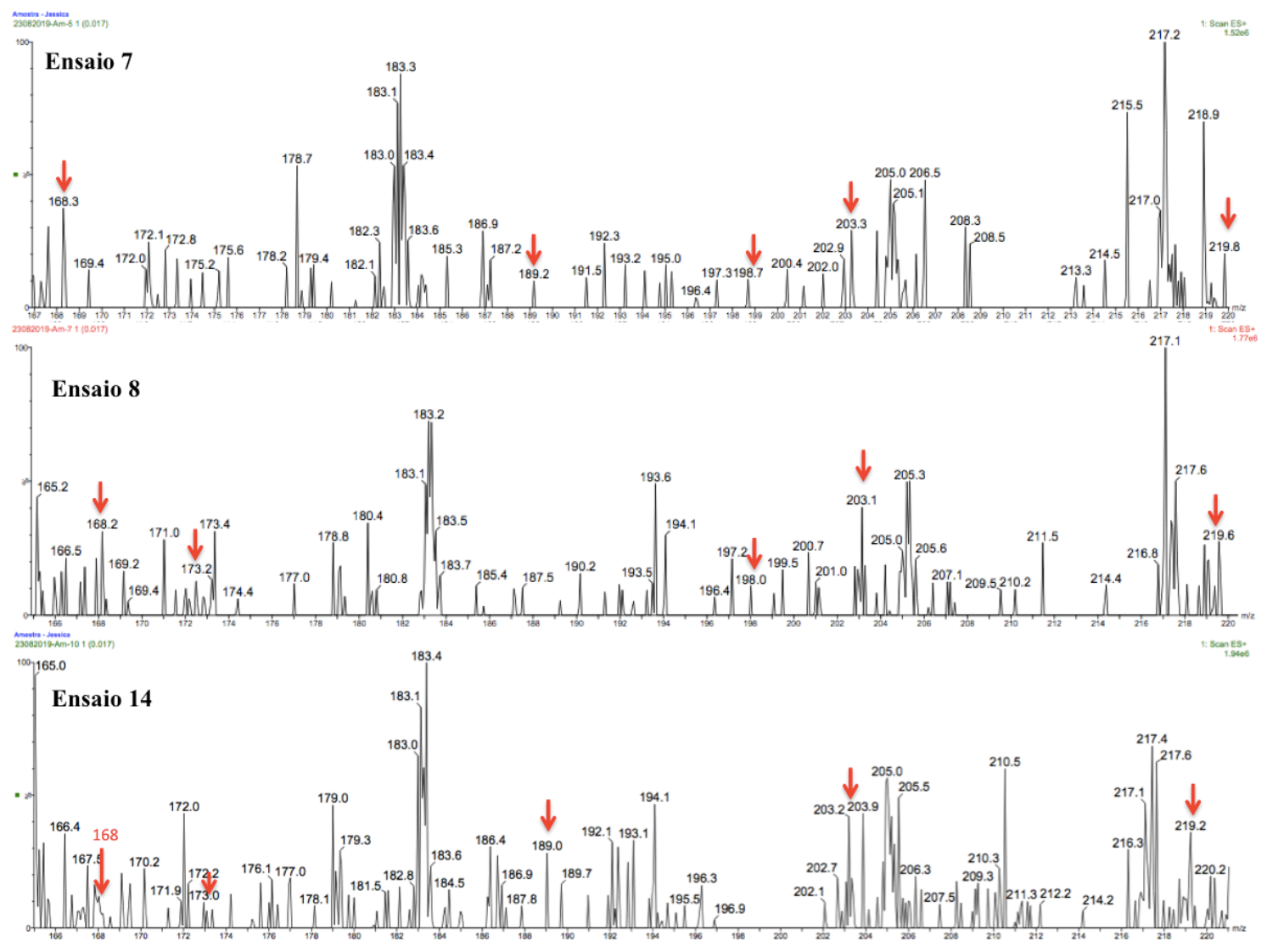


Figura 44. Espectros de massa dos produtos da hidrólise do xiloglucano com os ensaios 7, 8 e 10. Em destaque os picos de razão m/z correspondentes à massa de monômeros de xilose (na forma de adutos de amônio - 168 Da, de sódio -173 Da, e de potássio- 189 Da) e glicose ou galactose (como adutos de amônio- 198 Da, de sódio - 203 Da e de potássio$219 \mathrm{Da})$. Fonte: elaborado pela a autora.

É interessante notar que nas Figuras 43 e 44, em todos os espectros foi possível ver alguns picos de alta intensidade relativa, não relacionados a nenhum dos monossacarídeos ou dissacarídeos aqui considerados, como os picos de razão m/z 183, 205 e 217. Estes picos também estão presentes nos espectros da amostra da reação de controle negativo contendo somente xiloglucano e tampão (Figura 45). Portanto a presença destes picos está relacionada, provavelmente, com outros componentes da estrutura do xiloglucano ou de impurezas que foram extraídas junto com o polissacarídeo das sementes de jatobá.

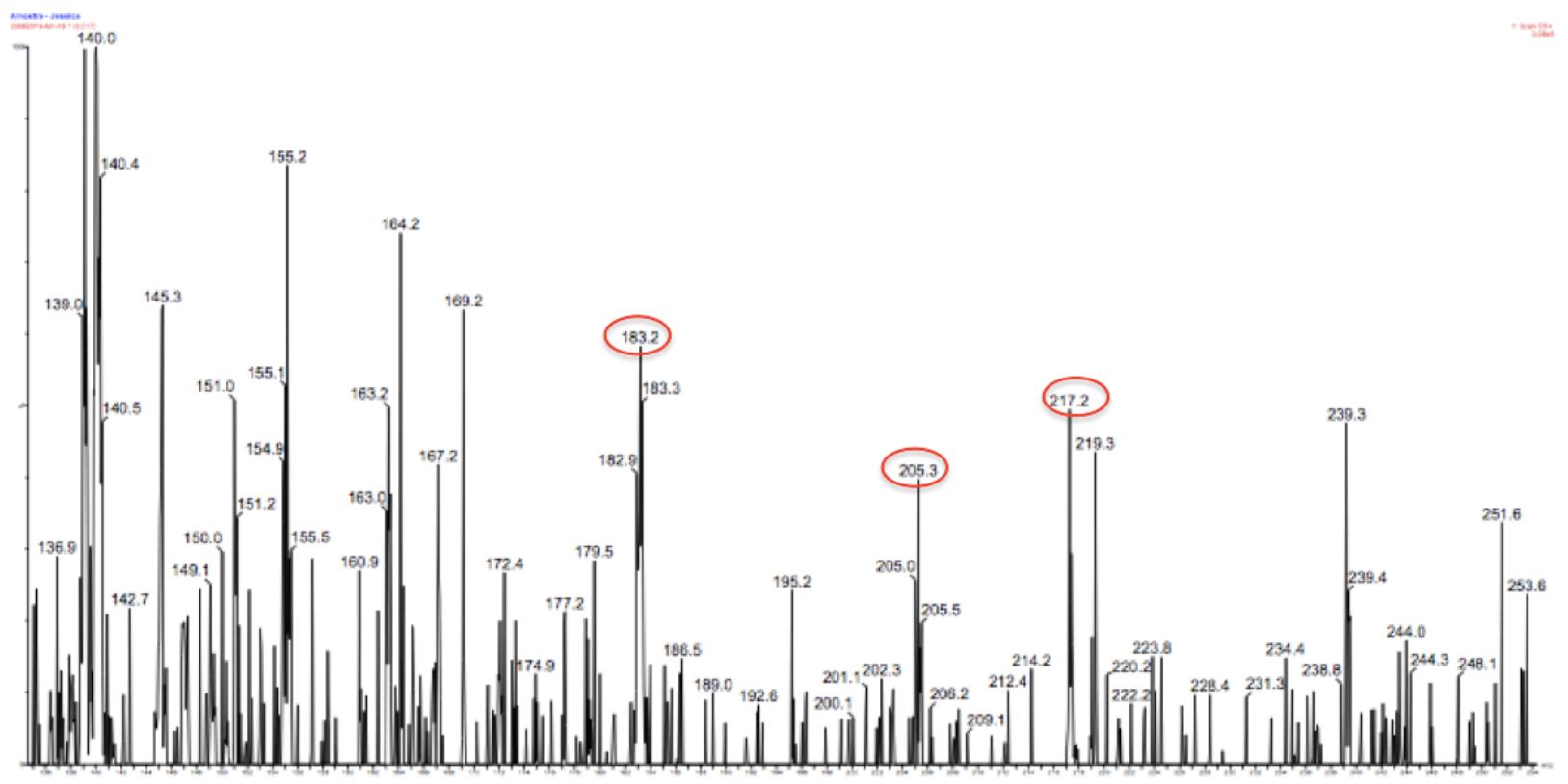

Figura 45. Espectros de massa dos produtos da hidrólise do xiloglucano, ensaio controle negativo. Fonte: elaborado pela a autora.

\subsection{Reuso nos nanossistemas para a hidrólise do xiloglucano}

Alguns dos ensaios de imobilização descritos na Tabela 8 foram selecionados para terem sua capacidade de reuso avaliada. Foram escolhidos os ensaios 4, 7 e 11, por demonstrarem uma boa performance nas análises anteriores, e na sua montagem, foram oferecidos 3 vezes mais enzimas, para uma quantidade 3 vezes maior de partículas, no intuito de aumentar a quantidade de monossacarídeos liberados nas suas respectivas reações de hidrólise e possibilitar uma mensuração 
de atividade e capacidade de reuso mais acurada. Assim, os três ensaios foram montados da seguinte forma: Ensaio 4 - 24 pmol de Bgl1, 24 pmol de Bga1, 408 pmol de XegA e 24 pmol de YicI ; Ensaio 7- 216 pmol de Bgl1, 24 pmol de Bga1, 216 pmol de XegA e 24 pmol de YicI; Ensaio 11- 24 pmol de Bgl1, 24 pmol de Bgal, 216 pmol de XegA e 216 pmol de YicI.

Todas as enzimas foram previamente diluídas em tampão fosfato de sódio $100 \mathrm{mM} \mathrm{pH} \mathrm{8,0.}$ Um total de $210 \mu \mathrm{L}$ contendo as devidas quantidades de enzimas e tampão foi misturado a $90 \mu \mathrm{L}$ de nanopartículas em reações de imobilização de 16 horas. As reações de hidrólise foram realizadas a $40{ }^{\circ} \mathrm{C}$ durante 90 minutos. Amostras de $10 \mu \mathrm{L}$ de cada reação tiveram a quantidade de glicose determinada pelo teste colorimétrico contendo glicose oxidase. Os resultados, em termos de glicose mensurada em cada ciclo de reuso, estão demonstrados na Figura 46.

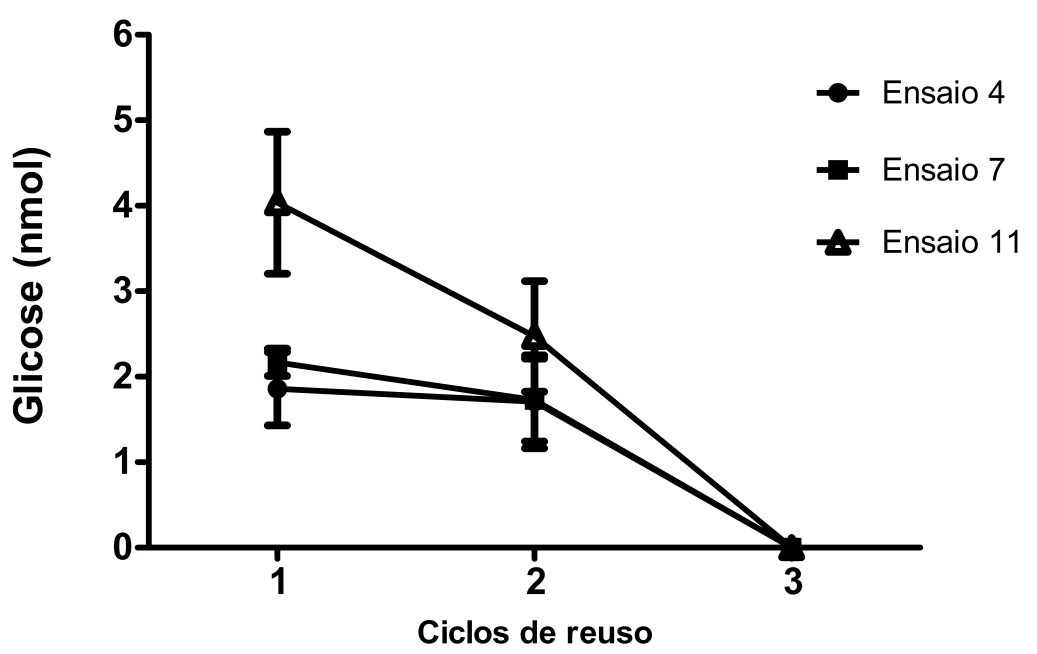

Figura 46. Ensaios de reuso dos nanossistemas híbridos. Fonte: elaborado pela autora

Com esses resultados notou-se que, dentre os ensaios analisados, o ensaio 11 (24 pmol de Bgl1, 24 pmol de Bga1, 216 pmol de XegA e 216 pmol de YicI ) teve mais atividade na despolimerização do xiloglucano, liberando mais açúcares durante as reações de hidrólise. Os ensaios 7 e 4 exibiram atividades bem próximas. Além disso, todos os ensaios aparentaram manter certa estabilidade no segundo ciclo de reuso, mais especificamente os ensaio 4 e 7 exibiram pouquíssima perda de atividade entre o primeiro e segundo reuso. No entanto, no terceiro reuso todo os ensaios exibiram atividade nula (a quantidade mensurada de glicose foi igual ou inferior à quantidade de glicose mensurada no ensaio controle-contendo apenas xiloglucano). 


\section{DISCUSSÃO}

O estudo de enzimas capazes de hidrolisar biomassas vegetais é importante não apenas para a produção de biocombustíveis, mas também é essencial para o entendimento da estrutura da parede celular de plantas e elucidação dos mecanismos envolvidos na despolimerização da biomassa vegetal. Alguns polissacarídeos vegetais são extremamente heterogêneos e sua composição pode variar bastante entre espécies vegetais diferentes. Esse é o caso do xiloglucano, um dos mais abundantes polissacarídeos hemicelulósicos que contribui para a complexa rede de polissacarídeos que define a arquitetura da parede celular. O xiloglucano possui, além da função estrutural, a função de sinalização e também a função de fixação da raiz ao solo em plantas terrestres (DEL-BEM, 2018; TINÉ; CORTELAZZO; BUCKERIDGE, 2000). O substrato escolhido para este trabalho, xiloglucano extraído da semente de Jatobá (H. courbaril) possui a característica de não ser fucosilado, mas é altamente galactosilado (BUCKERIDGE, 2010).

A estratégia adotada neste trabalho, de construção de um sistema híbrido nanoestruturado para a despolimerização do xiloglucano, pode ser considerada uma abordagem dentro do campo da biomimética molecular, onde se realiza o desenho de sistemas moleculares multifuncionais por meio da integração entre materiais inorgânicos, orgânicos e biológicos (SARIKAYA et al., 2003; TAMERLER et al., 2010). Assim, as nanopartículas utilizadas nesse trabalho foram idealizadas como nanoestruturas inorgânicas, capazes de se acoplarem a enzimas, formando um nanomaterial híbrido biomimético. Inicialmente, foi proposto que o nanomaterial híbrido fosse construído pela interação entre um cauda de histidina incluída na proteína de interesse, uma aplicação simples de engenharia de proteína já amplamente empregado como esquema de purificação, e as nanopartículas funcionalizadas com o metal quelante $\mathrm{Ni}^{2+}$. Esse nanomaterial foi desenvolvido e bem sucedido na co-localização das enzimas XegA e YicI. O sistema híbrido contendo essas duas enzimas manteve a atividade catalítica de ambas e ao ser incubado com o polissacarídeo xiloglucano, foi capaz de liberar oligossacarídeos com a xilose da extremidade não redutora removida (CARNEIRO, 2017).

No primeiro capítulo deste trabalho foram descritas as expressões de XegA e YicI contendo cauda de histidina e as tentativas de subclonagem dos genes de bgal e bgll em vetores engenheirados para a presença da cauda de histidina. As tentativas de subclonagem, tanto por CPEC quanto por ligação tradicional, não foram bem sucedidas. Provavelmente o tamanho do vetor empregado (aproximadamente $10 \mathrm{~kb}$ ) foi limitante em ambas as estratégias de clonagem. Apesar de a técnica do CPEC ser considerada prática e bastante versátil, o tamanho do plasmídeo pode ser um fator limitante (QUAN; TIAN, 2011). 
Enquanto a estratégia de imobilização por afinidade Histidina- $\mathrm{Ni}^{2+}$ é capaz de promover uma imobilização específica e pontual, a imobilização por ligação covalente através do glutaraldeído promove ligações inespecíficas multipontuais. Algumas das vantagens desse tipo de imobilização incluem principalmente a prevenção do fenômeno de dessorção e o aumento da estabilidade devido ao incremento na rigidez da molécula (CARDOSO; DE MORAES; CASS, 2009). Dessa forma, a estratégia de imobilização das enzimas nas nanopartículas para obtenção do nanossistema híbrido, foi reavaliada e optou-se pela abordagem de imobilização por ligação covalente.

No processo de formação das nanopartículas é empregado glutaraldeído como agente reticulador das partículas revestidas por quitosana. O glutaraldeído é geralmente a primeira escolha de agente reticulador (cross-linker), pois é um reagente de baixo custo e facilmente adquirido comercialmente, além de ser muito versátil. As reações promovidas pela presença de um agente reticulador geralmente envolvem grupos amino primários presente em resíduos de lisina na superfície da proteína com grupos dialdeídos, resultando na formação de bases de Shiff reversíveis. Uma posterior redução pode tornar a ligação irreversível. No entanto, quando o agente reticulador é o glutaraldeído, é possível ocorrer reações mais complexas que a base de Shiff (SHELDON; VAN PELT, 2013).

Geralmente, o glutaraldeído é empregado previamente à imobilização, na ativação do suporte, ou pode ser usado para promover o intercruzamento das proteínas já imobilizadas em suporte sólido. Quando o suporte é pré-funcionalizado pelo glutaraldeído, a ligação da proteína ao suporte acontece em duas etapas. Primeiramente, as moléculas de glutaraldeído se ancoram ao suporte que contém grupos amino. Após a funcionalização, alguns grupos carregados ainda prevalecem então a interação da proteína com o suporte é inicialmente dirigida por interações iônicas, e em um segundo estágio a ligação covalente é estabelecida. No que se refere às melhores condições de imobilização, um tampão de baixa força iônica facilita a primeira interação iônica entre enzima e suporte e também a formação da ligação covalente (BETANCOR et al., 2006).

Neste trabalho o suporte considerado são as nanopartículas revestidas de quitosana e a ativação deste biopolimero por glutaraldeído é um dos métodos de intercruzamento mais empregados, por causa dos grupos amino existentes na estrutura da quitosana, os quais reagem este agente em condições próximas da neutralidade. Mais especificamente, na reação entre quitosana e glutaraldeído, ocorre ataque nucleofílico dos grupos amino da quitosana aos grupos carbonilas do glutaraldeído. A ligação covalente entre os grupos amino do biopolímero e aldeído terminal do glutaraldeído é irreversível e resiste a valores extremos de $\mathrm{pH}$ e temperatura. (MENDES et al., 2011). 
Sabendo-se então que o glutaraldeído reage com a quitosana principalmente pela presença dos grupos amino, nas proteínas os principais grupos reativos são: o $\left(\mathrm{NH}_{2}\right)$ da lisina e arginina, o $\mathrm{CO}_{2} \mathrm{H}$ do ácido aspártico ou glutâmico, o $(\mathrm{OH})$ da serina ou treonina e o grupo $(\mathrm{SH})$ da cisteína. Estes, portanto, podem reagir a grupos do suporte que foram ativados pelo glutaraldeído, que introduz, por exemplo, grupos carbonila, o qual é susceptível a reações com os grupos nucleofílicos da enzima, sobretudo os grupos amino (CARDOSO; MORAES; CASS, 2009).

No caso das enzimas imobilizadas neste trabalho, a atividade catalítica diminuiu, para todas, após a imobilização covalente. Isso é comum, apesar desse tipo de imobilização possuir vantagens, principalmente em relação à estabilidade, existe a possibilidade da diminuição da atividade enzimática, devido à facilidade de alteração da conformação nativa da proteína (CARDOSO; DE MORAES; CASS, 2009). A imobilização covalente multipontual frequentemente promove o aumento da estabilidade e também seletividade, porém este último fator está muito relacionado à região na superfície da proteína onde são formadas as ligações covalentes. Por exemplo, ligações muito próximas ao sítio ativo podem causar diminuição da atividade, por bloqueio do sitio ativo ou alteração conformacional durante a catálise, enquanto a rigidificação em regiões opostas a do sitio ativo ou contendo loops instáveis pode levar ao aumento da estabilidade por reduzir mudanças conformacionais que levam à inativação (GRAZÚ et al., 2010; MATEO et al., 2007).

Com relação ao efeito do $\mathrm{pH}$ na atividade das enzimas imobilizadas, não foram observadas grandes mudanças em comparação ao perfil das enzimas livres, exceto para a enzima XegA que apresentou uma maior tolerância a pHs mais ácidos quando imobilizada. Essa mudança também pode ser atribuída ao aumento da rigidez na molécula proteica, uma vez que na imobilização covalente multipontual as distâncias relativas dos resíduos envolvidos nas ligações ao suporte tendem a permanecer inalteradas a mudanças conformacionais induzidas por agentes de distorção, incluindo valores extremos de $\mathrm{pH}$, por isso enzimas imobilizadas dessa forma tendem a ser mais estáveis (MATEO et al., 2007).

Na tabela 10, são apresentadas as proporções dos principais grupos reativos presentes em cada enzima, verificados através da análise das sequências proteicas pela ferramenta ProtParam (https://web.expasy.org/protparam/). Analisando a quantidade dos resíduos de aminoácidos reativos, principalmente os que contém o grupo amino (Lys e Arg), notou-se que YicI e Bgal contém as maiores proporções de Lys e Arg, e foram também essas enzimas que apresentaram maior capacidade de reuso quando imobilizadas. Isso pode estar relacionado, pois com uma maior presença desses aminoácidos, maior a probabilidade de formação de ligações covalentes e consequentemente, há menos dessorção da enzima do suporte e pode haver também aumento da estabilidade devido à rigidificação da estrutura. No entanto, o sucesso da imobilização covalente 
não está relacionado apenas à quantidade de ligações formadas, mas principalmente à região da estrutura proteica onde as ligações se formam. A diminuição da atividade para todas as enzimas, e também a mudança de $\mathrm{pH}$ ótimo em alguns casos, provavelmente se deve a alterações na conformação proteica necessária para catálise. Por sua vez, a diminuição da atividade nos experimentos de reuso pode estar associada tanto à dissociação das enzimas do suporte quanto à inativação da das enzimas pela imobilização.

Tabela 10. Quantidade relativa dos aminoácidos mais reativos em cada enzima

\begin{tabular}{|c|c|c|c|c|}
\hline \multirow{2}{*}{$\begin{array}{l}\text { Resíduos de } \\
\text { aminoácidos } \\
\text { reativos }\end{array}$} & \multicolumn{4}{|c|}{$\begin{array}{l}\text { Quantidade relativa (\%) de cada resíduo de aminoácido } \\
\text { em cada enzima }\end{array}$} \\
\hline & YicI & XegA & Bga1 & Bgl1 \\
\hline Lys & 4,3 & 3,4 & 4,2 & 3,5 \\
\hline Arg & 5,3 & 0,4 & 4,2 & 3,6 \\
\hline Asp & 6,1 & 4,2 & 5,1 & 5,5 \\
\hline Glu & 6,1 & 2,1 & 4,1 & 2,2 \\
\hline Ser & 4,8 & 15,1 & 8,3 & 8,8 \\
\hline Thr & 5,4 & 8,0 & 6,1 & 7,1 \\
\hline Cys & 1,7 & 0,8 & 0,2 & 0,8 \\
\hline
\end{tabular}

Fonte: elaborado pela autora

É importante notar que como as partículas empregadas neste trabalho não foram idealizadas para a imobilização covalente, o glutaraldeído sendo usado somente para reticulação das partículas 
revestidas com quitosana para posterior funcionalização com $\mathrm{AB}-\mathrm{NTA} / \mathrm{Ni}^{2+}$, não foram realizados testes de otimização das condições de imobilização covalente por glutaraldeído. Essa otimização poderia, muito provavelmente, ajudar a aumentar a eficiência de imobilização e a capacidade de reuso das enzimas imobilizadas. Essa etapa de otimização deveria incluir, por exemplo, o estudo da variação da concentração do glutaraldeído empregado nas produção das partículas e do uso de tampões de força iônica e pHs diferentes na etapa de imobilização das enzimas.

Com relação às abordagens que podem oferecer o controle de onde as ligações covalentes serão formadas, a mutagênese sítio-dirigida de proteínas permite a alteração de alguns aminoácidos na sequência proteica, podendo evitar, por exemplo, a formação de ligações covalentes em regiões muito próximas ao sítio-ativo ou promover a ligação em regiões que sejam interessantes para o aumento da estabilidade da enzima, por meio da alteração do aminoácido por outro aminoácido reativo, como a lisina. Grazú e colegas (2010), utilizaram esta estratégia para promover uma maior rigidificação da enzima penicilina $\mathrm{G}$ acilase (PGA), o que resultou em maior estabilidade e enantioseletividade para esta enzima.

No que se refere à caracterização das enzimas livres em solução, os resultados obtidos neste trabalho foram, em geral, equivalentes ao encontrado na literatura, apesar de algumas diferenças, principalmente para as enzimas expressas em P. pastoris. Tais dados podem ser comparados na Tabela 11.

De acordo com Gamauf e colaboradores (2007), a enzima Bgal, superexpressa no próprio fungo $H$. jecorina, demonstrou declínio da atividade em temperaturas superiores a $60^{\circ} \mathrm{C}$, no entanto, a Bgal empregada neste trabalho, expressa em P. pastoris, demonstrou declínio na atividade apenas em temperaturas superiores a $75^{\circ} \mathrm{C}$. Para Bgll, também expressa em P. pastoris por Chen e colaboradores (2011), a temperatura ótima determinada foi $70^{\circ} \mathrm{C}$ e decaiu drasticamente acima disso, enquanto que a temperatura ótima determinada neste trabalho, foi de $75^{\circ} \mathrm{C}$. 
Tabela 11. Comparação da caracterização enzimática realizada neste trabalho com trabalhos anteriores

\begin{tabular}{|c|c|c|c|}
\hline Enzima & $\begin{array}{c}\text { Características } \\
\text { determinadas neste } \\
\text { trabalho } \\
\text { (pH e temperatura } \\
\text { ótimos) }\end{array}$ & $\begin{array}{c}\text { Características } \\
\text { descritas na } \\
\text { literatura } \\
\text { (pH e temperatura } \\
\text { ótimos) }\end{array}$ & Referências \\
\hline XegA & $65^{\circ} \mathrm{C}$ e pH 5,5 & $60^{\circ} \mathrm{C}$ e $\mathrm{pH} 6,0$ & $\begin{array}{l}\text { DAMÁSIO et al., } \\
2012\end{array}$ \\
\hline YicI & $45^{\circ} \mathrm{C}$ e pH 6,5 & $\begin{array}{l}\text { Estabilidade térmica } \\
\text { ate } 47^{\circ} \mathrm{C} \text { e } \mathrm{pH} 7,0\end{array}$ & $\begin{array}{l}\text { OKUYAMA et al., } \\
2004\end{array}$ \\
\hline Bgal & $75^{\circ} \mathrm{C}$ e $\mathrm{pH} 4,0$ & $60^{\circ} \mathrm{C}$ e $\mathrm{pH} 5,0$ & $\begin{array}{l}\text { GAMAUF et al., } \\
2007\end{array}$ \\
\hline Bg11 & $75^{\circ} \mathrm{C}$ e $\mathrm{pH} 4,5$ & $70^{\circ} \mathrm{C}$ e $\mathrm{pH} 5,0$ & CHEN et al., 2011 \\
\hline
\end{tabular}

Quanto aos nanossistemas contendo as quatro enzimas co-imobilizadas, foi possível determinar que há manutenção atividade enzimática após a imobilização, pela mensuração de glicose liberada após os ensaios de hidrólise do xiloglucano e as análises por espectrometria de massas. O ensaio colorimétrico de dosagem de glicose não é um método robusto, e pode sofrer interferência pela presença de outro monossacarídeos como a galactose e a xilose. Ainda que o método não seja muito seletivo, os seus resultados indicam que existe a liberação de monossacarídeos nas reações de hidrólise do xiloglucano, comparando-se os resultados dos ensaios contendo os nanossistemas híbridos com o ensaio controle contendo apenas xiloglucano. Algumas técnicas mais robustas podem ser aplicadas para análise de oligossacarídeos e monossacarídeos para confirmar a hidrólise do xiloglucano, como a eletroforese para análise de polissacarídeos PACE (Polysaccharide Analysis using Carbohydrate Gel Electrophoresis) e as cromatografias líquidas de alta performance, incluindo HPAEC-PAD (High-Performance Anion Exchange with Pulsed Amperometric Detection) e HILIC (Hydrophilic Interaction Liquid Chromatography).

Em alguns dos espectros de massas provenientes da hidrólise do xiloglucano com as quatro enzimas foi identificada a presença de dissacarídeos xilose-glicose e/ou xilose-galactose e xilobiose. Os dois primeiros podem ser derivados da hidrólise do xiloglucano ou podem ser resultado de reações de transglicosilação, ou por envolverem xilose, transxilosilação. No caso da xilobiose, é improvável que esta seja resultado da reação de hidrólise. É possível que a reação de 
transxilosilação tenha sido catalisada pela $\alpha$-xilosidase YicI. A $\alpha$-xilosidase pertence à família GH 31, na qual suas enzimas atuam por um mecanismo de retenção envolvendo a formação de um intermediário glicosil-enzima. Na reação de catálise, na etapa de transferência do resíduo glicosil, o aceptor é uma molécula de água, porém se houver a presença de outro aceptor que não seja a água, a transglicosilação é catalisada ao invés da hidrólise (KANG et al., 2007; MORACCI et al., 2000). Kang e colaboradores (2007) usaram a capacidade de transxilosilação da enzima YicI para investigar a sua especificidade no sítio da aglicona, usando diferentes açúcares como aceptores e observaram a transferência do resíduo xilosil para glicose, manose, frutose e alose, mas não para galactose. Por outro lado, há evidiências de que $\beta$-galactosidases também são capazes de catalisar transglicosilação envolvendo xilose. Carneiro e colegas (2018), observaram a atividade de transglicosilação da $\beta$-galactosidase de Bacillus subtilis YesZ, com o substrato sintético $p$ NP-Gal na presença de xilose, formando como produto o dissacarídeo $\beta$-D-galactopiranosil- $(1 \rightarrow 4)$-Dxilopiranose. Portanto, no que se refere ao observado no presente trabalho, a análise dos produtos de reação de YicI (tanto livre como imobilizada), na presença de xilose e $p$ NP-Xil, por espectrometria de massas e TLC, por exemplo, pode confirmar se a formação de xilobiose é realmente catalisada por YicI ou não.

Embora não tenha sido possível mensurar a quantidade de proteína imobilizada nas nanopartículas, sabe-se que boa parte das enzimas se perde nas lavagens, considerando-se a baixa eficiência de imobilização das enzimas imobilizadas individualmente (exceto Bga1) e a diferença na quantidade de glicose liberada entre os ensaios com enzimas livres e enzimas imobilizadas. Além disso, a diminuição da atividade das enzimas pela imobilização provavelmente também afetou diretamente na eficiência da hidrólise do xiloglucano, o que foi evidenciado pela grande diferença entre os resultados dos ensaios de hidrólise com as enzima livres e imobilizadas. Apesar dessas diferenças foi possível comprovar que os nanossistemas são ativos na despolimerização do xiloglucano, constituindo então uma ferramenta nanobiotecnológica para a desplimerização de um polissacarídeo complexo. 
CONCLUSÕES 


\section{CONCLUSÕES}

Neste trabalho, foi possível realizar a expressão, purificação e caracterização das enzimas $\alpha$ xilosidase (YicI), endo- $\beta$-1,4-glucanase específica de xiloglucano (XegA), $\beta$-galactosidase (Bga1) e $\beta$-glucosidase (Bgl1) com êxito. Com relação às enzimas livres, as enzimas fúngicas Bga1 e Bgl1 apresentaram, no geral, maior atividade em pHs ácidos, de 3,5 a 5,0 e temperaturas altas, de $50^{\circ} \mathrm{C}$ a $75^{\circ} \mathrm{C}$ graus. XegA, enzima bacteriana, também apresentou melhores atividades em pHs mais ácidos $(2,5$ a 5,0) e YicI, funcionou melhor em condições mais brandas e próximas da neutralidade, $\mathrm{pH}$ de 5,0 a 6,5 e temperatura de $35^{\circ} \mathrm{C}$ a $45^{\circ} \mathrm{C}$.

Realizou-se a imobilização covalente de quatro enzimas ativa contra o xiloglucano, em nanopartículas ferromagnéticas revestidas com quitosana e reticuladas com glutaraldeido, o qual foi o agente promotor das ligações covalente.

Nos estudos de imobilização individual, cada enzima foi caracterizada, na sua forma livre e imobilizada, nos termos de temperatura e pH ótimos, além de análise do reuso para enzimas as imobilizadas. No geral, o pH ótimo para enzimas imobilizadas foi semelhante ao das enzimas livres, e a temperatura ótima foi variável, tendo sido aumentada em 10 graus no caso da enzima YicI imobilizada em relação à enzima livre. Para Bgal e Bgl1 também houve cerca de 10 graus de diferença entre as temperaturas ótimas de enzimas livres e imobilizadas, mas neste caso, com menores temperaturas ótimas para as imobilizadas. No caso de XegA, a temperatura ótima foi semelhante para ambas. A atividade específica diminuiu para todas as enzimas após a imobilização e tanto isso, quanto as alterações de $\mathrm{pH}$ e temperatura ótimos, provavelmente são consequências de alterações na conformação das proteinnas, devido à formação de múltiplas ligações covalentes com as nanopartículas.

As enzimas YicI e Bgal imobilizadas nas nanopartículas demonstraram as melhores capacidades de reuso e isso pode ter relação com quantidade de resíduos de aminoácidos lisina e arginina presentes na sua estrutura.

Nos estudos de hidrólise do xiloglucano pelos nanossistemas contendo as 4 enzimas coimobilizadas, foi possível verificar que as enzimas continuaram ativas, pela identificação da liberação de oligos e monossacarídeos do xiloglucano, portanto cumprindo o objetivo principal deste trabalho. 


\section{REFERÊNCIAS BIBLIOGÁFICAS}

ALISSON, E. Etanol de segunda geração poderá ser economicamente viável a partir de 2025. Disponível em: $<$ http://agencia.fapesp.br/etanol_de_segunda_geração_podera_ser_economicamente_viavel_a_parti r_de_2025/26272/>. Acesso em: 3 abr. 2019.

ANSARI, S. A.; HUSAIN, Q. Potential applications of enzymes immobilized on/in nano materials: A review. Biotechnology Advances, v. 30, n. 3, p. 512-523, maio 2012.

BALAT, M. Production of bioethanol from lignocellulosic materials via the biochemical pathway: A review. Energy Conversion and Management, v. 52, n. 2, p. 858-875, 1 fev. 2011.

BALAT, M.; BALAT, H. Recent trends in global production and utilization of bio-ethanol fuel. Applied Energy, v. 86, n. 11, p. 2273-2282, 1 nov. 2009.

BENKÖ, Z. et al. Evaluation of the role of xyloglucanase in the enzymatic hydrolysis of lignocellulosic substrates. Enzyme and Microbial Technology, v. 43, n. 2, p. 109-114, ago. 2008.

BETANCOR, L. et al. Glutaraldehyde in Protein Immobilization. In: GUISAN, J. M. (Ed.). . Immobilization of Enzymes and Cells. 2nd. ed. Totowa: Humana Press, 2006. p. 57-64.

BETANCOR, L.; LUCKARIFT, H. R. Co-immobilized coupled enzyme systems in biotechnology. Biotechnology and Genetic Engineering Reviews, 2010.

BON, E. P. S.; GÍRIO, F.; PEREIRA, N. Enzymes in ethanol production. In: BON, E. P. S.; FERRARA, M. A.; CORVO, M. L. (Eds.). . Enzymes in Biotechnology: Production, Aplications and Markets. Rio de Janeiro: Interciência, 2008. p. 241-271.

BÖTTCHER, D.; BORNSCHEUER, U. T. Protein engineering of microbial enzymes. Current Opinion in Microbiology, v. 13, n. 3, p. 274-282, jun. 2010.

BRADFORD, M. M. A rapid and sensitive method for the quantitation of microgram quantities of protein utilizing the principle of protein-dye binding. Analytical Biochemistry, v. 72, n. 1-2, p. 248-254, 7 maio 1976.

BUCKERIDGE, M. S. et al. A new family of oligosaccharides from the xyloglucan of Hymenaea courbaril L. (Leguminosae) cotyledons. Carbohydrate Research, 1997.

BUCKERIDGE, M. S. Seed Cell Wall Storage Polysaccharides: Models to Understand Cell Wall Biosynthesis and Degradation. PLANT PHYSIOLOGY, 2010.

BUSSAMRA, B. C. MELHORAMENTO DE COQUETÉIS ENZIMÁTICOS PARA A HIDRÓlISE DO BAGAÇO DE CANA-DE-AÇÚCAR. [s.l.] Universidade Estadual de Campinas - UNICAMP, 2014.

CARDOSO, C. L.; DE MORAES, M. C.; CASS, Q. B. Immobilization of the enzymes on chromatographic supports: A tool to research of inhibitor compounds. Quimica Nova, v. 32, n. 1, p. 175-187, 2009. 
CARNEIRO, L. A. B. C. et al. Characterization of a $\beta$-galactosidase from Bacillus subtilis with transgalactosylation activity. International Journal of Biological Macromolecules, v. 120, p. 279-287, 1 dez. 2018.

CARNEIRO, L. A. B. C.; WARD, R. J. Functionalization of paramagnetic nanoparticles for protein immobilization and purification. Analytical Biochemistry, v. 540-541, p. 45-51, jan. 2018.

CARNEIRO, L. A. B. C. Engenharia e caracterização de enzimas para a hidrólise de xiloglucano. [s.1.] Universidade de São Paulo, 2017.

CASTRO, H. et al. Imobilização de Enzimas e Sua Estabilização. In: BON, E. P. S.; FERRARA, M. A.; CORVO, M. L. (Eds.). . Enzimas em Biotecnologia:Produção, Aplicações e Mercado. [s.1.] Interciência, 2008. p. 241.

CHEN, P. et al. Expression of a secretory $\beta$-glucosidase from Trichoderma reesei in Pichia pastoris and its characterization. Biotechnology Letters, v. 33, n. 12, p. 2475-2479, 9 dez. 2011.

CHIBATA, I. Immobilized Enzymes. New York: John Wiley \& Sons, Ltd, 1978.

DAMASIO, A. R. DE L. et al. Xyloglucan breakdown by endo-xyloglucanase family 74 from Aspergillus fumigatus. Applied Microbiology and Biotechnology, v. 101, n. 7, p. 2893-2903, 24 abr. 2017.

DAMÁSIO, A. R. L. et al. Functional characterization and oligomerization of a recombinant xyloglucan-specific endo- $\beta$-1,4-glucanase (GH12) from Aspergillus niveus. Biochimica et Biophysica Acta (BBA) - Proteins and Proteomics, v. 1824, n. 3, p. 461-467, 1 mar. 2012.

DE OLIVEIRA, M. E. D.; VAUGHAN, B. E.; RYKIEL, E. J. Ethanol as Fuel: Energy, Carbon Dioxide Balances, and Ecological Footprint. BioScience, v. 55, n. 7, p. 593-602, 1 jul. 2005.

DE SOUZA, A. P. et al. Composition and Structure of Sugarcane Cell Wall Polysaccharides: Implications for Second-Generation Bioethanol Production. Bioenergy Research, v. 6, n. 2, p. 564-579, 2013.

DEL-BEM, L. E. Xyloglucan evolution and the terrestrialization of green plants. New Phytologist, v. 219, n. 4, p. 1150-1153, 1 set. 2018.

DUPREE, R. et al. Probing the Molecular Architecture of Arabidopsis thaliana Secondary Cell Walls Using Two- and Three-Dimensional ${ }^{13}$ C Solid State Nuclear Magnetic Resonance Spectroscopy. Biochemistry, v. 54, n. 14, p. 2335-2345, 2015.

FAN, L.-H. et al. Self-surface assembly of cellulosomes with two miniscaffoldins on Saccharomyces cerevisiae for cellulosic ethanol production. Proceedings of the National Academy of Sciences of the United States of America, v. 109, n. 33, p. 13260-5, 14 ago. 2012.

FIEROBE, H.-P. et al. Degradation of cellulose substrates by cellulosome chimeras. Substrate targeting versus proximity of enzyme components. The Journal of biological chemistry, v. 277, $\mathrm{n}$. 51, p. 49621-30, 20 dez. 2002.

FORNERA, S. et al. Sequential Immobilization of Enzymes in Microfluidic Channels for Cascade 
Reactions. ChemPlusChem, v. 77, n. 2, p. 98-101, 1 fev. 2012.

FURTADO, G. P. et al. Enhanced xyloglucan-specific endo- $\beta$-1,4-glucanase efficiency in an engineered CBM44-XegA chimera. Applied Microbiology and Biotechnology, v. 99, n. 12, p. 5095-5107, 2015.

GAMAUF, C. et al. Characterization of the bga1-encoded glycoside hydrolase family $35 \beta$ galactosidase of Hypocrea jecorina with galacto- $\beta$-d-galactanase activity. FEBS Journal, v. 274 , n. 7, p. 1691-1700, 1 abr. 2007.

GONSALVES, A. DE A. et al. Diferentes estratégias para a reticulação de quitosana. Química Nova, v. 34, n. 7, p. 1215-1223, 2011.

GRAZÚ, V. et al. Promotion of multipoint covalent immobilization through different regions of genetically modified penicillin G acylase from E. coli. Process Biochemistry, v. 45, n. 3, p. 390$398,2010$.

GUPTA, V. K. Microbial Enzymes in Bioconversions of Biomass. [s.1.] Springer International Publisher, 2016. v. 3

HARRIS, D.; DEBOLT, S. Synthesis, regulation and utilization of lignocellulosic biomassPlant Biotechnology Journal, 2010.

HONDA, T.; TANAKA, T.; YOSHINO, T. Stoichiometrically Controlled Immobilization of Multiple Enzymes on Magnetic Nanoparticles by the Magnetosome Display System for Efficient Cellulose Hydrolysis. Biomacromolecules, 2015.

JACOBSEN, S. E.; WYMAN, C. E. Cellulose and Hemicellulose Hydrolysis Models for Application to Current and Novel Pretreatment Processes. Applied Biochemistry and Biotechnology, v. 84-86, n. 1-9, p. 81-96, 2000.

KALKAN, N. A. et al. Preparation of chitosan-coated magnetite nanoparticles and application for immobilization of laccase. Journal of Applied Polymer Science, v. 123, n. 2, p. 707-716, 2012.

KANG, M.-S. et al. Aglycone specificity of Escherichia colia-xylosidase investigated by transxylosylation. FEBS Journal, v. 274, n. 23, p. 6074-6084, 1 dez. 2007.

KARKEHABADI, S. et al. Biochemical Characterization and Crystal Structures of a Fungal Family 3 beta-Glucosidase, Cel3A from Hypocrea jecorina. J.Biol.Chem., v. 289, p. 31624-31637, 2014.

KOYAMA, T. et al. Degradation of Xyloglucan by Wall-Bound Enzymes from Soybean Tissue II: Degradation of the Fragment Heptasaccharide from Xyloglucan and the Characteristic Action Pattern of the -D-Xylosidase in the Enzyme System. Plant and Cell Physiology, v. 24, n. 2, p. 155-162, 1 jan. 1983.

KUMAR, R.; SINGH, S.; SINGH, O. V. Bioconversion of lignocellulosic biomass: Biochemical and molecular perspectivesJournal of Industrial Microbiology and Biotechnology, 2008.

LAEMMLI, U. K. Cleavage of Structural Proteins during the Assembly of the Head of Bacteriophage T4. Nature, v. 227, n. 5259, p. 680-685, ago. 1970. 
LAL, R. Carbon sequestration. Philosophical transactions of the Royal Society of London. Series B, Biological sciences, v. 363, n. 1492, p. 815-30, 27 fev. 2008.

LEE, S.-M. et al. $\beta$-Glucosidase coating on polymer nanofibers for improved cellulosic ethanol production. Bioprocess and Biosystems Engineering, v. 33, n. 1, p. 141-147, 23 jan. 2010.

LIANG, H. et al. Co-immobilization of multiple enzymes by metal coordinated nucleotide hydrogel nanofibers: improved stability and an enzyme cascade for glucose detection. Nanoscale, v. 8, n. 11, p. $6071-6078,2016$.

LINDNER, J. et al. Governo cria meta de redução de 10\% das emissões de combustíveis até 2028 . O Estado de São Paulo, 5 jun. 2018.

LYND, L. R. et al. Microbial Cellulose Utilization: Fundamentals and Biotechnology. Microbiology and Molecular Biology Reviews, v. 66, n. 4, p. 739-739, 2002.

LYND, L. R. et al. How biotech can transform biofuels. Nature Biotechnology, v. 26, n. 2, p. 169172, fev. 2008.

MAKSIMAINEN, M. et al. Crystal structures of Trichoderma reesei beta-galactosidase reveal conformational changes in the active site. J.Struct.Biol., v. 174, p. 156-163, 2011.

MATEO, C. et al. Improvement of enzyme activity, stability and selectivity via immobilization techniques. Enzyme and Microbial Technology, v. 40, n. 6, p. 1451-1463, 2007.

MCANDREW, R. P. et al. From soil to structure, a novel dimeric $\beta$-glucosidase belonging to glycoside hydrolase family 3 isolated from compost using metagenomic analysis. The Journal of biological chemistry, v. 288, n. 21, p. 14985-92, 24 maio 2013.

MENDES, A. A. et al. Aplicação de quitosana como suporte para imobilização de enzimas de

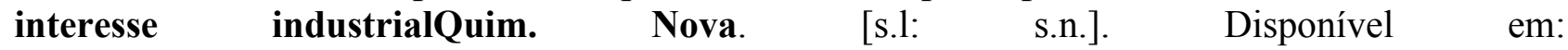
$<$ http://quimicanova.sbq.org.br/imagebank/pdf/Vol34No5_831_18-RV10441.pdf $>$. Acesso em: 11 maio. 2019.

MENON, V.; RAO, M. Trends in bioconversion of lignocellulose: Biofuels, platform chemicals \&amp; biorefinery concept. Progress in Energy and Combustion Science, v. 38, n. 4, p. 522-550, 1 ago. 2012.

MILANEZ, A. Y. et al. De promessa a realidade: como o etanol celulósico pode revolucionar a indústria da cana-de-açúcar - uma avaliação do potencial competitivo e ssugestões de política pública. BNDES Setorial, v. 42, p. 237-294, 2015.

MILLER, G. L. Use of Dinitrosalicylic Acid Reagent for Determination of Reducing Sugar. Analytical Chemistry, v. 31, n. 3, p. 426-428, mar. 1959.

MINISTÉRIO DO MEIO AMBIENTE. Acordo de Paris. Disponível em: $<$ https://www.mma.gov.br/clima/convencao-das-nacoes-unidas/acordo-de-paris $>$. Acesso em: 10 ago. 2019.

MORACCI, M. et al. Identification and molecular characterization of the first alpha -xylosidase 
from an archaeon. The Journal of biological chemistry, v. 275, n. 29, p. 22082-9, 21 jul. 2000.

NELSON, J.; GRIFFIN, E. G. Adsorption of Invertase. Journal of American Chemical Society, v. 38 , n. 5, p. 1119, 1916.

OKUYAMA, M. et al. Overexpression and characterization of two unknown proteins, YicI and YihQ, originated from Escherichia coli. Protein Expression and Purification, v. 37, n. 1, p. 170179, 1 set. 2004.

OKUYAMA, M. et al. Structural elements to convert Escherichia coli $\alpha$-xylosidase (YicI) into $\alpha$ glucosidase. FEBS Letters, v. 580, n. 11, p. 2707-2711, 15 maio 2006.

OLSSON, L. et al. Bioethanol Production from Lignocellulosic Material. In: DUMITRIU, S. (Ed.). . Polysaccharides : Structural diversity and functional versatility. New York: Marcel Dekker, 2005. p. 957-993.

PAN, C. et al. Novel and efficient method for immobilization and stabilization of $\beta$-d-galactosidase by covalent attachment onto magnetic Fe3O4-chitosan nanoparticles. Journal of Molecular Catalysis B: Enzymatic, v. 61, n. 3-4, p. 208-215, dez. 2009.

PEREIRA, S. et al. 2G ethanol from the whole sugarcane lignocellulosic biomass. Biotechnology for Biofuels, v. 8, n. 1, p. 44, 2015.

PIPPO, W. A. et al. Energy recovery from sugarcane-trash in the light of 2 nd generation biofuels. Part 1: Current situation and environmental aspects. Waste and Biomass Valorization, v. 2, n. 1, p. 1-16, 2011.

QUAN, J.; TIAN, J. Circular polymerase extension cloning for high-throughput cloning of complex and combinatorial DNA libraries. Nature Protocols, v. 6, n. 2, p. 242-251, 2011.

READ, S. M.; NORTHCOTE, D. H. Minimization of variation in the response to different proteins of the Coomassie blue G dye-binding assay for protein. Analytical Biochemistry, v. 116, n. 1, p. 53-64, 1 set. 1981.

ROCHA, M. S. R. DOS S.; ALMEIDA, R. M. R. G.; DA CRUZ, A. J. G. Avaliação Do Potencial Energético De Resíduos Agroindustriais Provenientes De Diferentes Regiões Brasileiras. Engevista, v. 19, n. 1, p. 217-235, 2017.

ROCHA, V. A. L. et al. Sugarcane bagasse as feedstock for cellulase production by Trichoderma harzianum in optimized culture medium. Electronic Journal of Biotechnology, v. 16, n. 5, 15 set. 2013.

RUSMINI, F.; ZHONG, Z.; FEIJEN, J. Protein immobilization strategies for protein biochipsBiomacromolecules, 2007.

SAMBROOK, J.; RUSSEL, D. W. Molecular Cloning: A Laboratory Manual. 3. ed. New York: Cold Spring Harbor Laboratory Press, 2001.

SARIKAYA, M. et al. Molecular biomimetics: nanotechnology through biology. Nature Materials, 2003. 
SARKO, A. Cellulose - How Much We Know About Its Structure? In: Wood and Cellulosics: Industrial Utilisation. Biotechnology, Strucure and Properties. New York: John Wiley \& Sons, Ltd, 1997.

SHELDON, R. A.; VAN PELT, S. Enzyme immobilisation in biocatalysis: Why, what and how. Chemical Society Reviews, v. 42, n. 15, p. 6223-6235, 2013.

SONG, Q. et al. Cellulase immobilization on superparamagnetic nanoparticles for reuse in cellulosic biomass conversion. AIMS Bioengineering, v. 3, n. 3, p. 264-276, 2016.

SU, C.-K. et al. Enzyme-Immobilized 3D-Printed Reactors for Online Monitoring of Rat Brain Extracellular Glucose and Lactate. Analytical Chemistry, v. 88, n. 12, p. 6265-6273, 21 jun. 2016.

SWEENEY, M. D.; XU, F. Biomass Converting Enzymes as Industrial Biocatalysts for Fuels and Chemicals: Recent Developments. Catalysts, v. 2, n. 4, p. 244-263, 2012.

TAMERLER, C. et al. Molecular biomimetics: GEPI-based biological routes to technology.Biopolymers, 2010.

TANG, W. L.; ZHAO, H. Industrial biotechnology: Tools and applicationsBiotechnology Journal, 2009.

TINÉ, M. A. S.; CORTELAZZO, A. L.; BUCKERIDGE, M. S. Xyloglucan mobilisation in cotyledons of developing plantlets of Hymenaea courbaril L. (Leguminosae-Caesalpinoideae). Plant Science, v. 154, n. 2, p. 117-126, 2000.

TIWARI, P.; MISRA, B. N.; SANGWAN, N. S. $\beta$-Glucosidases from the fungus trichoderma: an efficient cellulase machinery in biotechnological applications. BioMed research international, $\mathrm{v}$. 2013, p. 203735, 1 ago. 2013.

UNCTAD, U. N. C. O. T. A. D. Second-Generation Biofuel Markets: State of Play, Trade and Developing Country Perspectives. United Nations Publications, 2016.

UNICA. UNIÃO DA INDÚSTRIA DE CANA-DE-AÇÚCAR. Disponível em: $<$ http://www.unica.com.br>.

UNICA. Etanol 2G deve ganhar escala com nova fábrica da Clariant. Disponível em: $<$ http://www.unica.com.br/noticia/191870639203981924/etanol-2g-deve-ganhar-escala-com-novafabrica-da-clariant/>. Acesso em: 9 jun. 2019.

UNICA, U. DA I. DE C.-A. Etanol De Segunda Geração Poderá Ser Economicamente Viável a Partir De 2025. Disponível em: <http://www.unica.com.br/na-midia/59555049203981924/etanolde-segunda-geracao-podera-ser-economicamente-viavel-a-partir-de-2025-/>.

VINUEZA, N. R. et al. Analysis of xyloglucans by ambient chloride attachment ionization tandem mass spectrometry. Carbohydrate Polymers, v. 98, n. 1, p. 1203-1213, 15 out. 2013.

WANG, J.; ZHANG, G. Progress in co-immobilization of multiple enzymes. Shengwu Gongcheng Xuebao/Chinese Journal of Biotechnology, v. 31, n. 4, p. 469-480, 2015. 
WEN, F.; NAIR, N. U.; ZHAO, H. Protein engineering in designing tailored enzymes and microorganisms for biofuels production. Current Opinion in Biotechnology, v. 20, n. 4, p. 412419, 2009.

WŁODARCZYK-BIEGUN, M. K.; DEL CAMPO, A. 3D bioprinting of structural proteins. Biomaterials, v. 134, p. 180-201, jul. 2017.

WOODLEY, J. M. Protein engineering of enzymes for process applicationsCurrent Opinion in Chemical Biology, 2013.

YANG, Y. et al. High Activity and Convenient Ratio Control: DNA-Directed Coimmobilization of Multiple Enzymes on Multifunctionalized Magnetic Nanoparticles. ACS Applied Materials \& Interfaces, 2017. 


\title{
ANEXO A - Sequência do gene yicI e sequência da proteína YicI
}

\author{
>LN832404.1:3828731-3831049 Escherichia coli K-12 genome assembly EcoliK12AG100, \\ chromosome :
} TTACAACGTAATTGTCAGCGCATTCCCTTGAGGCTTCACCACCAGCCCCTGCTCACTTTCAGCCTGCGAA CCGTCTTGCAGACCATTTACTTTCACAACATTGCGCAGGCACAGTGTCCAGTTCTTCGCCTCGCCCGCAC CAGTCACAGTAATCGTGTTGCCAGTACGTGCTGCTTTTAAAGTAAAGATCACCGATCCGTCAGCAGCGGG CACTTCACAGACGGCTTCATGCCCGTCTTGCAGATTGAAGAGGTGGAATGCCGTGCCTTCGTGCCACACG TAATCGGGACGTTGATCGTTGTTGCCCAGCGCCAGTAGAGTGTTATCACGCACATAAACGGGCAGACTCA GGAAGCCGTGCTGCTGTTTATGCCAGCGACTACCGTCGAGTTCATCGTTGTGCCACAGGTGTGTCCAGCG ACCTTCCGGCAGGTAGAACTGCACATCGCCCGCTTCAGTGAACACCGGCGCAACCATCACGTTGTCGCCT AACATGTATTGACGGTCAAGGTAATCACAAGCCGGATCGTCCGGGAACTCCATCATCATGGCCCGCATCA TCGGCGTACCCCGCGCGTTCGCACGCGCAGCTTCACGATACAGATACGGCATCATGCGGCATTTCAGTTG CGTGAAGAAGCGCACCACATCACAGGACTCATCATCGTAGGCCCACGGCACACGATAAGATTTGCTACCG TGTAAACGGCTATGGCTGGAGAGCAAACCAAACGCGCACCAGCGTTTGTAAACGTGCGCCGGAGCGGTAT TTTCAAAGCCGCCGATATCGTGGCTCCAGAAGCCAAAACCTGAAAGGCCAATAGACAAACCACCGCGCAG GCTTTCCGCCATTGATTCGTAGTTAGCGTAACAATCGCCACCCCAGTGTACCGGGAATTTCTGCGCACCG ACGGAGGCCGAGCGGGCAAACAAGACAGCTTCTTCCTCACCAACGGTGTCCTTGAGCACGTTCCACACCA GTTCGTTGTAGATGTACGCATAATGGTTATGCATTTTCTGCGGATCGGAACCGTCAAACCACTGAACATC AGTTGGGATACGTTCGCCAAAGTCGGTCTTAAAGCAATCAACGCCCATCGCGACCAGACCTTTCAGTTTG TCGGCGTACCATTTGCAGGCATCCGGATTGGTAAAGTCATAAATCGCCAGACCTGGCTGCCATTTATCCC ACTGCCATAGCGAACCGTCCGGGCGTTTGAGTAAATAGCCTTTCTCTTGTAACTCTTTAAAGACGGGGGA TTTTTGACCGATATAGGGGTTAATCCAGACGCAGATTTTCAGTCCTTTCGCTTTCAGGCGGCGGATCATC CCTTCCGGGTCAGGGAAAGTCAGCGGGTCCCACTCAAAATCGCACCACTGGAAGGCTTTCATCCAGAAAC AGTCAAAGTGGAAAACATGCAGCGGCAGATTGCGTTCCGCCATACCATCGATAAAGCTGTTTACCGTCGC TTCGTCGTAGTTGGTGGTAAATGAAGTGGTTAGCCACAGGCCGAAGGACCACGCGGGCGGCAGCGCCGGA CGACCAGTAAAGCGGGTATAACGATCAAGTACCGCTTTCGGCGTCGGGCCGTCGATAACAAAGTATTCGA GATATTCACTCTCAACGCTGAACTGCACTTTGGAGACTTTCTCCGATCCCACTTCAAAAGAGACACACTG GGGATGATTGACCAGTACCCCATAACCACGGTTAGTCATGTAGAACGGGATATTTTTATACGCCTGTTCA GTACTTGTGCCGCCGTCCCGGTTCCAGGTCTCTACCGTCTGGCCATTGCGCACCAGGGCAGTAAAGCGCT CTCCCAGACCGTAAACTGTTTCGCCAACGCCAAGATCAAGCCGCTCAAACATATAATTGCGTTGATTATT CGTGTCCTGCACGTAGCCATTATTTTTCACCTGACTACCGGTAATACGTTCGCCGTTGCGCAGAAAATCC AGTGACCAGAACTCACCTTTGCTGACACGCGCGCTTAAGTTGCCACTTTTAAACTCAGCATAACGTTCTG TGTTTTCGATTGTGACCTTCACGTCCTGCAAAATATTGAGCGGATAATGAGGACCGTTATTCAGCGCCCC CTGAAAATGCTCAATCCGCACACCGACAATACCTTCCTGTGGGGAGAAAAAGCGCAACGTAAATAAAGGC GTATCAAGCTGCCAGGTACGTTCACGCACATCACGGGGGGCAGCATAGACCACCATTTCATTATCCTGCT GTTCAACCTCGAACACCTGAAGCGGGTGAATCAAATTGAGGCCAGGTTGAATCAACCAGTTTCCATCGCT AАTTTTCAT

\footnotetext{
>AIZ53469.1 putative alpha-glucosidase [Escherichia coli K-12] MKISDGNWLIQPGLNLIHPLQVFEVEQQDNEMVVYAAPRDVRERTWQLDTPLFTLRFFSPQEGIVGVRIE HFQGALNNGPHYPLNILQDVKVTIENTERYAEFKSGNLSARVSKGEFWSLDFLRNGERITGSQVKNNGYV QDTNNQRNYMFERLDLGVGETVYGLGERFTALVRNGQTVETWNRDGGTSTEQAYKNIPFYMTNRGYGVLV NHPQCVSFEVGSEKVSKVQFSVESEYLEYFVIDGPTPKAVLDRYTRFTGRPALPPAWSFGLWLTTSFTTN YDEATVNSF I DGMAERNLPLHVFHFDCFWMKAFQWCDFEWDPLTFPDPEGMIRRLKAKGLKICVWINPYI GQKSPVFKELQEKGYLLKRPDGSLWQWDKWQPGLAIYDFTNPDACKWYADKLKGLVAMGVDCFKTDFGER IPTDVQWFDGSDPQKMHNHYAYIYNELVWNVLKDTVGEEEAVLFARSASVGAQKFPVHWGGDCYANYESM AESLRGGLSIGLSGFGFWSHDIGGFENTAPAHVYKRWCAFGLLSSHSRLHGSKSYRVPWAYDDESCDVVR FFTOLKCRMMPYLYREAARANARGTPMMRAMMMEFPDDPACDYLDROYMLGDNVMVAPVFTEAGDVOFYL PEGRWTHLWHNDELDGSRWHKQQHGFLSLPVYVRDNTLLALGNNDQRPDYVWHEGTAF HLFNLQDGHEAV CEVPAADGSVIFTLKAARTGNTITVTGAGEAKNWTLCLRNVVKVNGLQDGSQAESEQGLVVKPQGNALTITL
} 


\section{ANEXO B - Sequência do gene xega e sequência da proteína XegA}

>JN222918.1 Aspergillus niveus strain PR-2 xyloglucan-specific endo-beta-1,4glucanase GH12 gene, complete cds

ATGAAGCTTAGCCTCTCTGTCGCCCTCTCGCTCGCCGCATCGACTGCCCAGGCAGCCACCCAGTTCTGTG ACCAATGGGGCTCGGTCACCGAGGGCAACTACATTCTTTACAACAATCTTTGGGGTCAGGCCCAGGCCAC GTCCGGCTCCCAGTGCACCACGTTCGAATCTCTTTCGGGCAACACGATCGTCTGGAACACCAAGTGGTCT TGGTCCGGTGGCCAGGGCCAGGTGAAGAGTTTCGCCAATGCCGCTCTGCAGTTCACCCCCAAGAAACTGA GCAGCGTCAAGAGCATTGACTCGACTTGGAAGTGGAACTATTCTGGCTCCAACATTGTCGCCGATGTTGC CTACGACATGTTCCTCAGCACGTCCCCCGGCGGCGACCACAACTACGAGATCATGGTCTGGCTAGGTGCT TTGGGCGGCGCTGGTCCCATTTCCTCGACGGGCTCGCCCATCGCCACGCCCACCGTCGCTGGCATCAAGT TTAACCTGTACCTCGGCCCGAACGGCTCGATGCAGGTGTACAGCTTCGTGGCCCAGTCGACCACGAATAG СTTCTCCGGCGACATGCGCGACTTCTTTACGTACCTGGAAAGCAACCAAGGTCTGTCCAGCGACCTGTAC CTGGTCGACGTGCAGGCCGGTACCGAGCCCTTCAGCGGAAGCAATGCCGTTTTCACGGTATCCGACTACT CTGTCAGTGTCGCCTAA

translation= "MKLSLSVALSLAASTAQAATQFCDQWGSVTEGNYILYNNLWGQA QATSGSQCTTFESLSGNTIVWNTKWSWSGGQGQVKSFANAALQFTPKKLSSVKS IDST WKWNYSGSNIVADVAYDMFLSTSPGGDHNYE IMVWLGALGGAGP ISSTGSPIATPTVA GIKFNLYLGPNGSMQVYSFVAQSTTNSFSGDMRDFFTYLESNQGLSSDLYLVDVQAGT EPFSGSNAVFTVSDYSVSVA" 


\section{ANEXO C - Sequência do gene bga1 e sequência transcrita da proteína Bga1}

>XM_006967496.1 Trichoderma reesei QM6a glycoside hydrolase family 35 (TRIREDRAFT_80240), partial mRNA ATGATGAGACCC̄GTCTCTCTGCTGTCAGCAGTTGTTCTGCTGCTCACAGGCATCGATGCCACGAGCATCG GTCTTCACGGCGGGCGACCTCGTGATATCATCCTCGACGATGCAAAAGGGCCCCTTCAAAACATCGTCAC ATGGGACGAACATTCGCTTTTTGTTCATGGCGAGCGCGTCGTCATCTTCTCTGGCGAAGTCCATCCATTT CGTCTGCCCGTGCCGTCTCTGTATCTTGATGTGTTCCACAAGATCAAAGCTCTTGGGTTCAACACAGTAT CGTTCTATGTGGACTGGGCGCTTCTAGAAGGAAAGCCCGGCAGATTCCGCGCCGACGGCATATTCAGCCT GGAGCCCTTCTTCGAGGCTGCCACCAAGGCCGGCATTTACCTGCTGGCCCGCCCGGGGCCTTATATCAAC GCCGAGGTGTCGGGAGGCGGCTTTCCGGGCTGGCTGCAGAGGGTCAAGGGCAAGCTGAGAACAGATGCTC CCGATTACCTACACGCCACGGACAACTATGTGGCTCACATTGCCTCGATCATTGCAAAGGCACAGATCAC AAACGGAGGACCAGTGATTCTGTACCAGCCAGAAAACGAGTACAGCGGCGCTGCGGAGGGCGTTTTGTTC CCGAACAAGCCATACATGCAGTACGTGATTGACCAGGCGCGAAATGCCGGCATCATTGTGCCTCTCATCA ACAACGATGCCTTTCCTGGAGGCACAGGTGCCCCTGGTACGGGCCTTGGATCGGTAGATATCTACGGCCA TGATGGCTATCCTCTCGGTTTTGACTGTGCTCATCCCTCCGCCTGGCCTGACAACGGGTTGCCTACGACG TGGCGTCAGGACCATCTCAACATTAGTCCAAGCACACCATTTTCTCTTGTTGAGTTCCAAGGTGGTGCGT TTGATCCTTTCGGCGGCTGGGGTTTCGAACAATGCTCTGCCCTAGTCAACCACGAGTTTGAGCGAGTTTT СTATAAGAACAATATGGCAGCTGGTGTGACCATCTTCAACATATACATGACCTTTGGCGGCACCAACTGG GGCAATCTCGGCCACCCTGGCGGTTATACATCGTACGACTATGGAGCTAGCATCAGAGAAGACCGTAGGA TTGACAGAGAAAAGTATTCCGAGCTGAAGTTGCAGGGTCAGTTCCTCAAGGTCTCCCCGGGGTACATCAC CGCTACGCCGGAAAACGCAACGCAAGGCGTATACAGCGACAGTCAAAACATTGTCATAACGCCGCTCCTA GCCAAGGAAAGCGGTGATTTCTTCGTCGTGCGCCATGCAAACTACTCGAGCACAGACACGGCGTCTTATA CGGTCAAGCTGCCCACCTCTGCAGGAGACCTCACAATCCCTCAGCTGGGCGGTTCGCTTACTTTGACCGG ACGAGACTCCAAGATCCATGTCACCGACTACCCCGTTGGAAAGTTCACATTGCTATACTCTACTGCAGAG ATATTCACGTGGAACGAGTTTGCCGAAAAGACTGTTTTGGTCTTGTACGGGGGCGCACAAGAGCTGCACG AATTTGCCGTCAAGAACCCATTCGGAAGCTCGAAGACCGCCAAAGCCAAGAAGATTGAAGGGAGCAACGT САСTATTCATACGACAAGCAATCTGACAGTTGTCCTTCAATGGACGGCTTCCTCTGCCAGGCAGGTTGTA CAGCTGGGTTCTCTCGTCATCTACATGGTTGATCGCAACTCTGCGTACAACTACTGGGTTCCСACTCTCC CCGGAAGCGGCAAGCAGTCAGCCTACGGAAGCTCCCTCATGAATCCTGATTCCGTCATAATAAACGGAGG СTACCTCATCCGCTCCGTGGCCATCAAGGGCAATGCTCTCTCGGTGCAGGCAGATTTCAACGTCACAACG CCGCTCGAGATCATTGGCATTCCAAAAGGCATCTCAAAGCTCGCTGTCAACGGAAAAGAGCTCGGCTACT CGGTGTCTGAACTCGGAGACTGGATCGCCCACCCAGCCATTGAGATTCCACACGTCCAGGTCCCAGAGTT GACAAAGCTGAAATGGTACAAGGTTGACTCCCTTCCCGAGATTCGGAGCAACTACGATGACTCCCGCTGG CCACTTGCCAATCTCCGAACCTCGAACAACACCTACGCCССTCTCAAAACGCCTGTATCGCTCTACGGCT CTGACTATGGCTTCCACGCCGGAACGCTCCTCTTTCGCGGCCGCTTCACAGCCCGCACTGCGCGACAGCA GCTCTTCCTCTCGACCCAGGGCGGCTCGGCCTTTGCCAGCTCCGTCTGGCTCAACGACCGCTTCATCGGC TCCTTCACCGGCTTCGACGCCGCCAGCGCCGCCAACTCGTCCTACACGCTCGACAGACTCGTCCGTGGCC GGCGCTACATCCTCACGGTCGTCGTCGACTCCACGGGCCTCGACGAGAACTGGACCACCGGCGACGACTC AATGAAGGCCCCCCGCGGCATCCTCGACTACGCACTCACCTCCTCCTCCGGAGCAAACGTGTCGATATCG TGGAAACTCACAGGCAACCTCGGCGGCGAGGACTACCGCGACGTCTTCCGCGGGCCCCTCAACGAAGGCG GCCTCTTCTTCGAGCGGCAGGGCTTCCATCTGCCCTCTCCGCCGCTCAGCGACTTTACCCACGGCCCGTC СТСTTCСTCTTCTTCTTCTTCGCCCCTCGACGGCATCGCCCACGCGGGCATCGCCTTTTACGCCGCAAAG CTGCCCCTCCATCTCCCGGCGCAAGAGTACGACATTCCGTTGTCGTTTGTCTTTGACAACGCCACCGCCG CCGCGCCGTACCGGGCTCTGCTCTACGTCAACGGCTTCCAGTACGGCAAGTACGTCAGCAACATTGGCCC GCAGACCGAGTTCCCCGTGCCCGAGGGCATCCTCGACTACAACGGCGACAACTGGATCGGCGTTGCGCTA TGGGCGTTGGAGAGCCGTGGCGCCAAGGTCCCTGGCTTGGCGCTCAAGAGCAAGTCGCCGATTCTCACGG GGAGGGAAAGGGTTGAGGTGGTCAAGGGGCCGCATTTCAAGAAGCGGCACGGGGCGTACTGA

\footnotetext{
>translation $="$

MMRPVSLLSAVVLLLTGIDATS IGLHGGRPRDI ILDDAKGPLON

IVTWDEHSLFVHGERVVIFSGEVHPFRLPVPSLYLDVFHKIKALGFNTVSFYVDWALL EGKPGRFRADGIFSLEPFFEAATKAGIYLLARPGPY INAEVSGGGFPGWLQRVKGKLR TDAPDYLHATDNYVAH IAS I IAKAQITNGGPVILYQPENEYSGAAEGVLF PNKPYMQY VIDQARNAGI IVPLINNDAFPGGTGAPGTGLGSVDIYGHDGYPLGFDCAHPSAWPDNG LPTTWRQDHLNISPSTPFSLVEFQGGAFDPFGGWGFEQCSALVNHEFERVFYKNNMAA GVTIFNIYMTFGGTNWGNLGHPGGYTSYDYGAS IREDRRIDREKYSELKLQGQFLKVS PGYITATPENATQGVYSDSQNIVITPLLAKESGDFFVVRHANYSSTDTASYTVKLPTS AGDLTIPQLGGSLTLTGRDSKIHVTDYPVGKFTLLYSTAEIFTWNEFAEKTVLVLYGG AQELHEFAVKNPFGSSKTAKAKKIEGSNVTIHTTSNLTVVLQWTASSARQVVQLGSLV IYMVDRNSAYNYWVPTLPGSGKQSAYGSSLMNPDSVI INGGYLIRSVAIKGNALSVQA DFNVTTPLEI IGIPKGISKLAVNGKELGYSVSELGDWIAHPAIE I PHVQVPELTKLKW
} 
YKVDSLPEIRSNYDDSRWPLANLRTSNNTYAPLKTPVSLYGSDYGFHAGTLLFRGRFT ARTARQQLFLSTQGGSAFASSVWLNDRFIGSFTGFDAASAANSSYTLDRLVRGRRYIL TVVVDSTGLDENWTTGDDSMKAPRGILDYALTSSSGANVSISWKLTGNLGGEDYRDVF RGPLNEGGLFFERQGFHLPSPPLSDFTHGPSSSSSSSSPLDGIAHAGIAFYAAKLPLH LPAQEYDIPLSFVFDNATAAAPYRALLYVNGFQYGKYVSNIGPQTEFPVPEGILDYNG DNWIGVALWALESRGAKVPGLALKSKSPILTGRERVEVVKGPHFKKRHGAY" 


\section{ANEXO D - Sequência do gene bgl1 e sequência transcrita da proteína Bgl1}

GCAGTCGTCCCTCCAGCAGGAACTCCTTGGGGTACAGCCTATGATAAAGCAAAGGCTGCCTTGGCTAAGTTGAACCTTCA AGATAAAGTCGGTATTGTTTCTGGTGTCGGATGGAACGGTGGACCATGTGTTGGTAATACTTCCCCTGCTTCAAAGATTA GTTATCCATCTTTGTGCCTTCAGGATGGTCCTTTGGGAGTTAGATACTCCACCGGTTCAACTGCTTTTACACCAGGAGTT CAAGCAGCTTCTACTTGGGACGTCAATTTGATTAGAGAAAGAGGACAGTTCATCGGAGAAGAGGTTAAGGCCTCCGGTAT TCATGTTATCCTTGGACCAGTCGCAGGTCCTTTGGGAAAAACTCCTCAAGGTGGAAGAAACTGGGAGGGTTTTGGAGTTG ATCCATATTTGACAGGTATTGCTATGGGACAGACCATTAATGGTATCCAATCTGTCGGAGTTCAGGCCACCGCAAAGCAT TACATCCTTAACGAACAAGAGTTGAACAGAGAAACTATCTCTTCCAACCCTGATGACAGAACCTTGCACGAGCTTTATAC TTGGCCATTCGCTGATGCCGTTCAGGCCAATGTTGCATCAGTCATGTGTAGTTACAACAAGGTTAACACTACATGGGCTT GCGAAGATCAATACACCTTGCAGACTGTTCTTAAAGACCAATTGGGTTTTCCTGGATACGTTATGACTGACTGGAACGCC CAACACACCACTGTTCAGAGTGCAAATTCTGGTTTGGATATGTCTATGCCAGGTACTGACTTCAACGGAAACAATAGACT TTGGGGTCCTGCTTTGACAAATGCCGTTAACTCAAATCAAGTCCCAACCAGTAGAGTTGATGACATGGTCACTAGAATTC TTGCCGCATGGTATTTGACAGGTCAAGATCAGGCTGGATACCCTTCTTTTAACATCTCCAGAAACGTTCAAGGTAACCAT AAGACTAATGTCAGAGCAATTGCTAGAGATGGAATCGTTTTGCTTAAAAACGACGCTAATATTTTGCCACTTAAGAAACC TGCTTCTATCGCCGTTGTCGGTTCCGCTGCCATTATCGGAAACCACGCTAGAAATTCTCCATCCTGTAACGATAAGGGTT GCGATGACGGAGCATTGGGTATGGGATGGGGTTCTGGAGCTGTTAACTACCCATATTTTGTCGCACCTTACGATGCTATT AATACTAGAGCATCAAGTCAAGGTACACAGGTTACCTTGTCAAACACTGACAATACATCTTCCGGTGCCAGTGCAGCTAG AGGAAAAGATGTTGCTATTGTCTTCATCACTGCCGACTCCGGTGAAGGATATATTACAGTTGAGGGTAACGCTGGAGATA GAAACAATCTTGACCCTTGGCATAACGGTAATGCCTTGGTTCAAGCCGTCGCAGGAGCTAACTCTAATGTTATTGTTGTC GTTCACTCCGTCGGTGCTATTATCTTGGAACAAATCTTGGCCCTTCCTCAGGTTAAGGCCGTCGTTTGGGCAGGTTTGCC ATCCCAAGAGTCAGGAAATGCTCTTGTCGATGTTTTGTGGGGTGACGTTTCACCTAGTGGAAAGTTGGTCTATACCATTG CTAAGTCACCAAACGATTACAACACTAGAATCGTTTCTGGTGGATCTGATTCCTTTTCAGAAGGTTTGTTCATTGACTAC AAGCATTTCGATGACGCTAACATCACACCTAGATACGAGTTTGGTTATGGATTGTCTTACACCAAGTTCAATTACAGTAG ATTGTCTGTTCTTTCCACTGCTAAATCCGGTCCAGCAACAGGAGCTGTCGTTCCAGGTGGACCTTCAGATTTGTTCCAAA ACGTTGCAACAGTCACCGTTGACATTGCTAATTCAGGTCAAGTTACTGGAGCCGAAGTCGCACAGCTTTACATCACATAT CCATCAAGTGCTCCTAGAACCCCACCTAAGCAATTGAGAGGTTTTGCCAAATTGAACCTTACACCTGGACAGTCCGGAAC TGCAACATTCAATATCAGAAGAAGAGATTTGTCATACTGGGACACCGCTAGTCAAAAGTGGGTCGTTCCAAGTGGTTCTT TTGGAATCAGTGTCGGAGCATCATCAAGAGATATTAGACTTACATCAACCCTTAGTGTCGCT

Translation

AVVPPAGTPWGTAYDKAKAALAKLNLODKVGIVSGVGWNGGPCVGNTSPASKISYPSLCLQDGPLGVRYSTGSTAFTPGV QAASTWDVNLIRERGQF I GEEVKASGI HVILGPVAGPLGKTPQGGRNWEGFGVDPYLTGIAMGQTINGIQSVGVQATAKH YILNEQELNRETISSNPDDRTLHELYTWPFADAVQANVASVMCSYNKVNTTWACEDQYTLQTVLKDQLGFPGYVMTDWNA QHTTVQSANSGLDMSMPGTDFNGNNRLWGPALTNAVNSNQVPTSRVDDMVTRILAAWYLTGQDQAGYPSFNISRNVQGNH KTNVRAIARDGIVLLKNDANILPLKKPAS IAVVGSAAI I GNHARNSP SCNDKGCDDGALGMGWGSGAVNYPYFVAPYDAI NTRASSQGTQVTLSNTDNTSSGASAARGKDVAIVF ITADSGEGY ITVEGNAGDRNNLDPWHNGNALVQAVAGANSNVIVV VHSVGAI ILEQILALPQVKAVVWAGLPSQESGNALVDVLWGDVSPSGKLVYTIAKSPNDYNTRIVSGGSDSF SEGLFIDY KHFDDANITPRYEFGYGLSYTKFNYSRLSVLSTAKSGPATGAVVPGGPSDLFQNVATVTVDIANSGQVTGAEVAQLYITY PSSAPRTPPKQLRGFAKLNLTPGQSGTATFNIRRRDLSYWDTASQKWVVPSGSFGISVGASSRDIRLTSTLSVA 